INTERNATIONAL MONETARY FUND

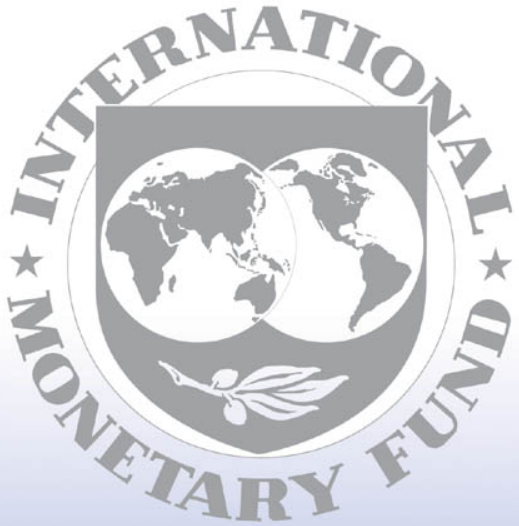

Staff

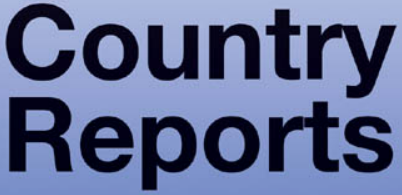




\title{
Malta: 2009 Article IV Consultation-Staff Report; Supplement; Public Information Notice on the Executive Board Discussion; and Statement by the Executive Director for Malta
}

Under Article IV of the IMF's Articles of Agreement, the IMF holds bilateral discussions with members, usually every year. In the context of the 2009 Article IV consultation with Malta, the following documents have been released and are included in this package:

- The staff report for the 2009 Article IV consultation, prepared by a staff team of the IMF, following discussions that ended on June 22, 2009, with the officials of Malta on economic developments and policies. Based on information available at the time of these discussions, the staff report was completed on August 5, 2009. The views expressed in the staff report are those of the staff team and do not necessarily reflect the views of the Executive Board of the IMF.

- A supplement of August 5, 2009, updating information on recent developments.

- $\quad$ A Public Information Notice (PIN) summarizing the views of the Executive Board as expressed during its September 4, 2009 discussion of the staff report that concluded the Article IV consultation.

- A statement by the Executive Director for Malta.

The policy of publication of staff reports and other documents allows for the deletion of market-sensitive information.

Copies of this report are available to the public from

International Monetary Fund • Publication Services

$70019^{\text {th }}$ Street, N.W. • Washington, D.C. 20431

Telephone: (202) 623-7430 • Telefax: (202) 623-7201

E-mail: publications@imf.org •Internet: http://www.imf.org

\author{
International Monetary Fund \\ Washington, D.C.
}


INTERNATIONAL MONETARY FUND

MALTA

\section{Staff Report for the 2009 Article IV Consultation}

Prepared by the Staff Representatives for the 2009 Consultation with Malta

(In consultation with other departments)

Approved by Ajai Chopra and Ranil Salgado

August 5, 2009

\section{Executive Summary}

Background: While the financial sector has so far weathered the global turmoil relatively unscathed, the real economy has been decelerating since the last quarter of 2008. However, inflation failed to moderate, while the fiscal position deteriorated sharply in 2008, owing to oneoffs and spending slippages. The current account deficit improved to $5 \frac{1}{2}$ percent of GDP.

Challenges: The immediate goal for fiscal policy should be to mitigate the negative spillovers on activity from the global crisis without compromising the already fragile public finances. To preserve competitiveness, Malta will have to complete its structural reform agenda as it emerges from the downturn.

Staff views: The fiscal stance for 2009 is appropriate, and stimulus withdrawal should be limited in 2010. However, fiscal consolidation should resume forcefully once the recovery is established, and the fiscal framework should be strengthened. Supervision needs to keep up with the rapidly expanding financial sector, and banks should set capital buffers and provisions more proactively, while labor market reforms and reduced state involvement in the economy would support competitiveness for the post-crisis.

Authorities' views: The authorities' short-term priority is to help the corporate sector withstand the crisis, with a view to minimize job losses. They nonetheless aim to cut the fiscal deficit in line with EU recommendations, predicated on a more favorable outlook than that of the staff. Though committed to medium-term fiscal consolidation, they have not articulated underlying measures to achieve it. They credited conservative lending practices and effective supervision for the benign impact of the global crisis on Maltese banks.

Mission team: C. Allard (Head), L. Lusinyan and V. Herzberg (all EUR) visited Malta on June 11-22, 2009 and held discussions with the Minister of Finance, the Governor of the Central Bank of Malta, and other key central bank and government officials, as well as representatives of the private sector and the opposition, social partners, and academics. 
Executive Summary

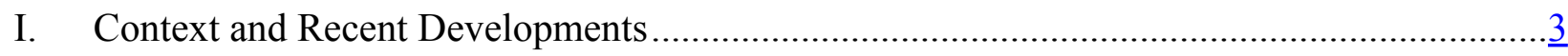

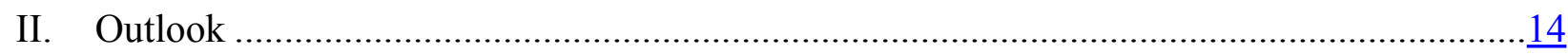

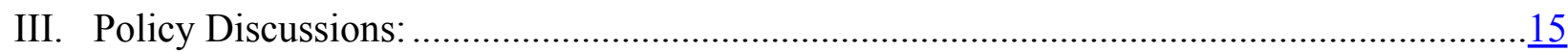

A. Preserving Fiscal Sustainability In A Recession .................................................15

B. Maintaining Financial Stability ………………..............................................

C. Fostering Malta's Competitiveness ………………..............................................

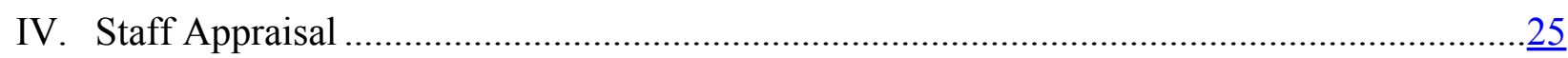

Box

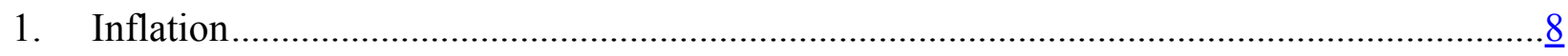

Figures

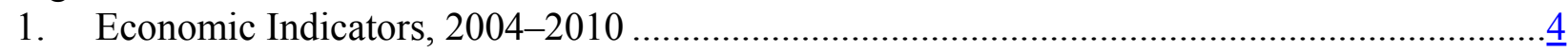

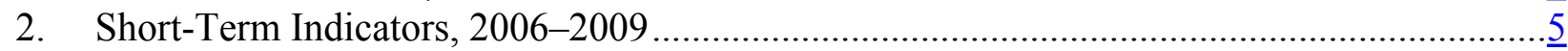

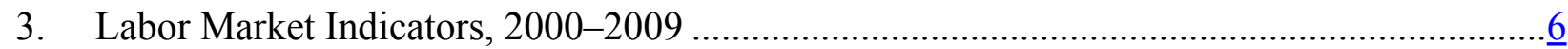

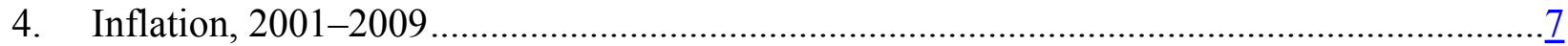

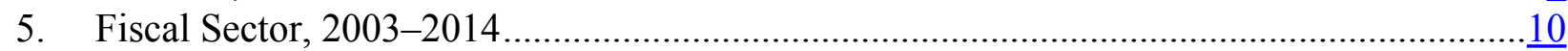

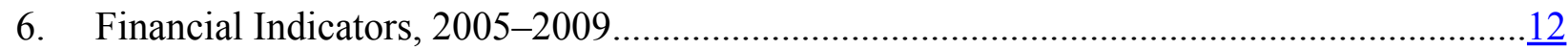

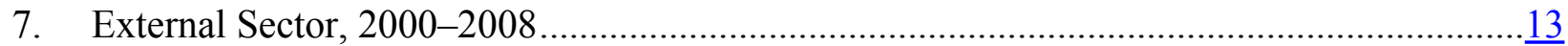

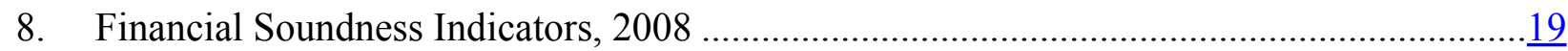

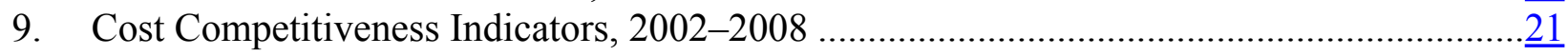

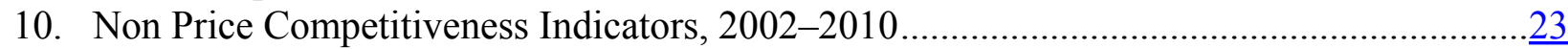

Tables

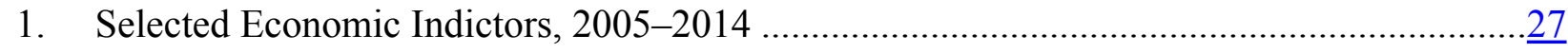

2. Fiscal Developments and Projections, 2004-2014 …..................................................

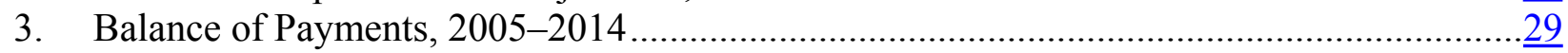

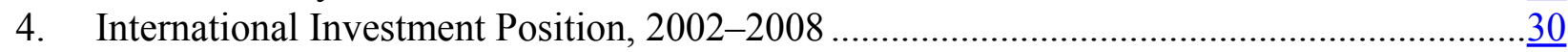

5. External Debt Sustainability Framework, 2004-2014 ....................................................

6. Public Sector Debt Sustainablity Framework, 2004-2014 …………………….................32

7. Financial Soundness Indicators, 2004-2008 ……....................................................

8. Indicators of External and Banking Sector Vulnerability, 2004-2009.................................

Appendix

1. Malta's Banking Sector: Recent Developments And Risks to Banking Sector

Stability 


\section{Context And Recent Developments ${ }^{1}$}

\section{Malta's economy is facing its first test following successful EU entry in 2004 and euro adoption in 2008.} Largely as the outcome of liberalizing reforms, Malta experienced a sustained expansion starting in the middle of the decade, underpinned by diversification to higher valueadded exports. But the unfavorable external environment is now challenging the economy's resilience, threatening to unravel past efforts at fiscal consolidation, and possibly holding back the reform impetus, even as the convergence process remains incomplete.

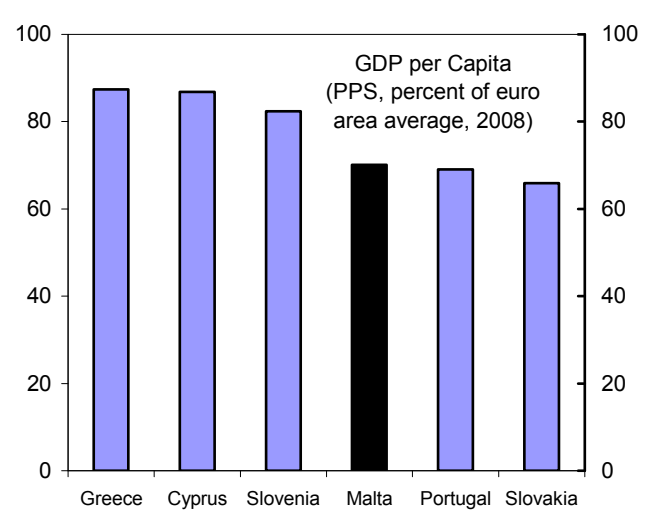

\section{The global economic crisis has started affecting Malta's real sector. Following} annual average growth of $3 \frac{1}{2}$ percent in $2005-07$, the expansion of the economy slowed to $2 \frac{1}{2}$ percent in 2008 , hampered by declining trade flows and investment as Malta's main trade partners entered severe recession (Figures 1 and 2, Table 1). Semiconductor production and tourism, accounting respectively for 15 and close to 25 percent of GDP, were particularly affected. Private consumption, resilient so far, also weakened in the beginning of 2009, as employment prospects deteriorated. However, activities in servicesinto which Malta's economy substantially diversified over the last few years - continued to hold.

\section{The labor market was resilient before worsening at the end of 2008 (Figure 3).}

Job creation remained strong, driven by the services industries. Average compensation per employee rose $2 \frac{1}{4}$ percent throughout the year, exceeding the across-the-board mandatory indexation to the cost of living (COLA), even though labor productivity gains tapered off. In particular, public wages, covered by a multi-annual collective agreement, increased by $4 \frac{1}{4}$ percent. More recently, however, labor market conditions started deteriorating, with the unemployment rate inching up since the fall of 2008, to reach 7.1 percent in May 2009.

4. Inflation has remained stubbornly high, topping the euro area since October 2008 and reaching 23/4 percent in June 2009 (Figure 4, Box). While there does not appear to have been any notable inflation boost due to euro adoption in January 2008, the positive output gap likely played a role. Additionally, the authorities increased utility tariffs in October 2008 , food price inflation failed to moderate, reflecting an imperfect pass-through of the decline in international food prices, and prices in the hospitality sector remained buoyant until the recent deterioration in tourism. In contrast, housing price inflation continued moderating throughout 2008, with prices falling by about 10 percent in the first quarter of 2009 , in part because of oversupply in certain segments of the market.

\footnotetext{
${ }^{1}$ This report reflects data until end-July 2009.
} 
Figure 1. Malta: Economic Indicators, 2004-2010
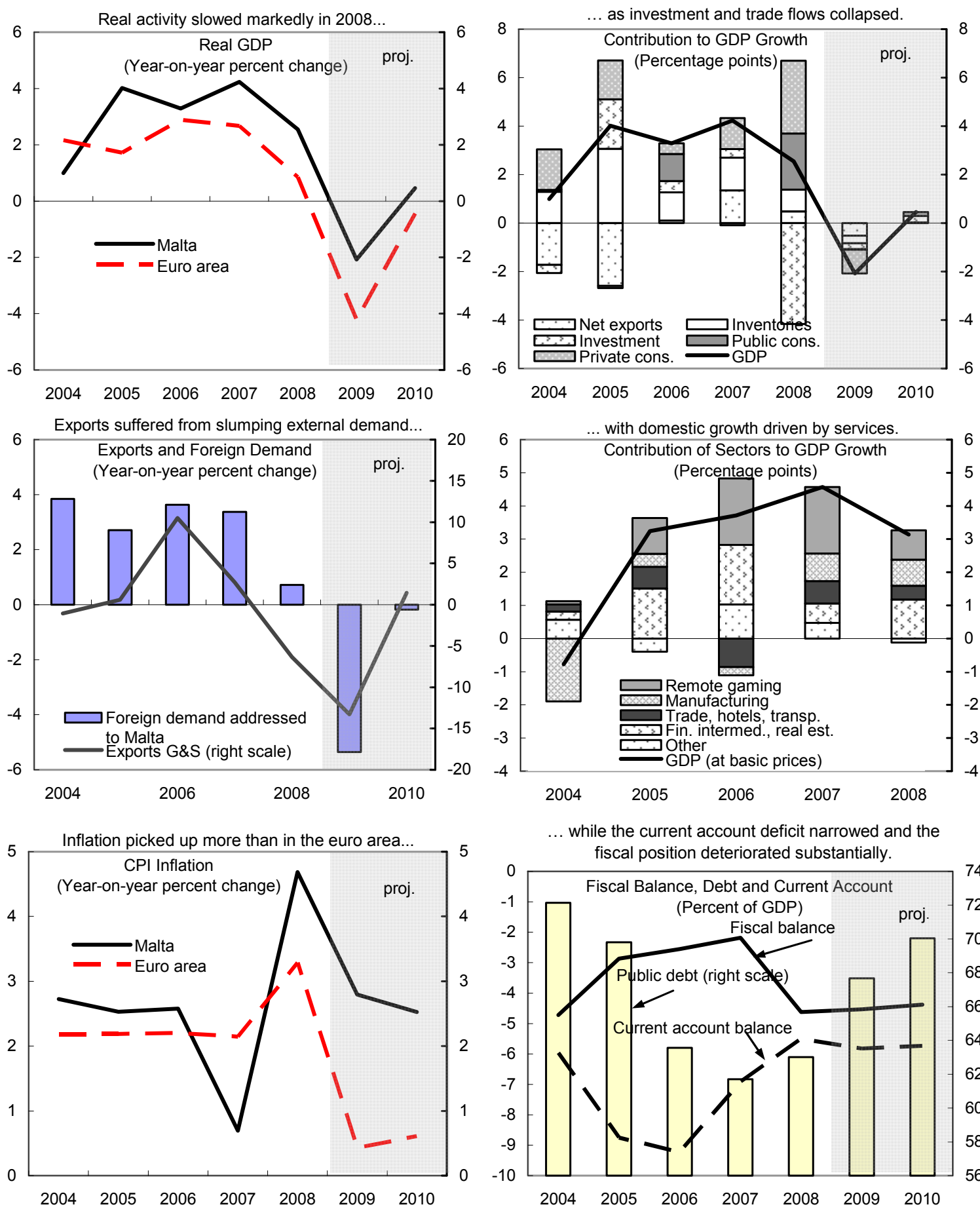

... while the current account deficit narrowed and the fiscal position deteriorated substantially.

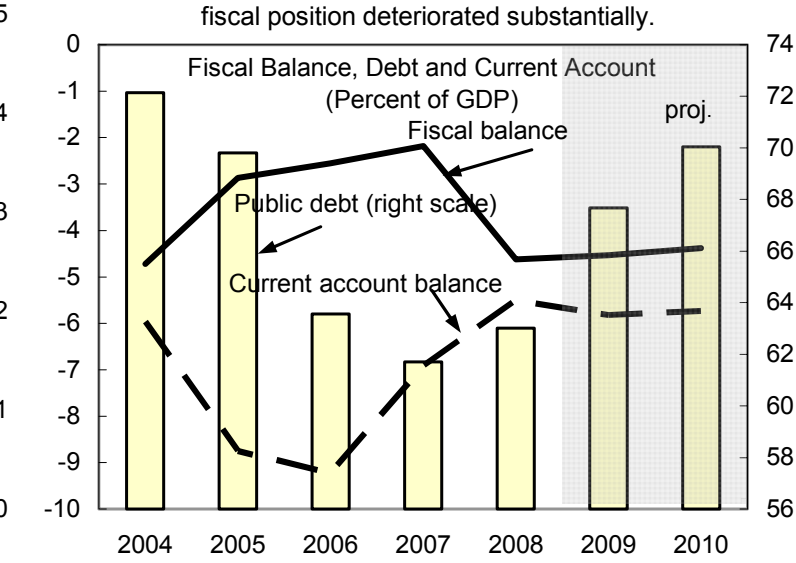

Sources: Central Bank of Malta; Eurostat; WEO; and IMF staff estimates. 
Figure 2. Malta: Short-Term Indicators, 2006-2009

The slump in goods exports has been led by semi-
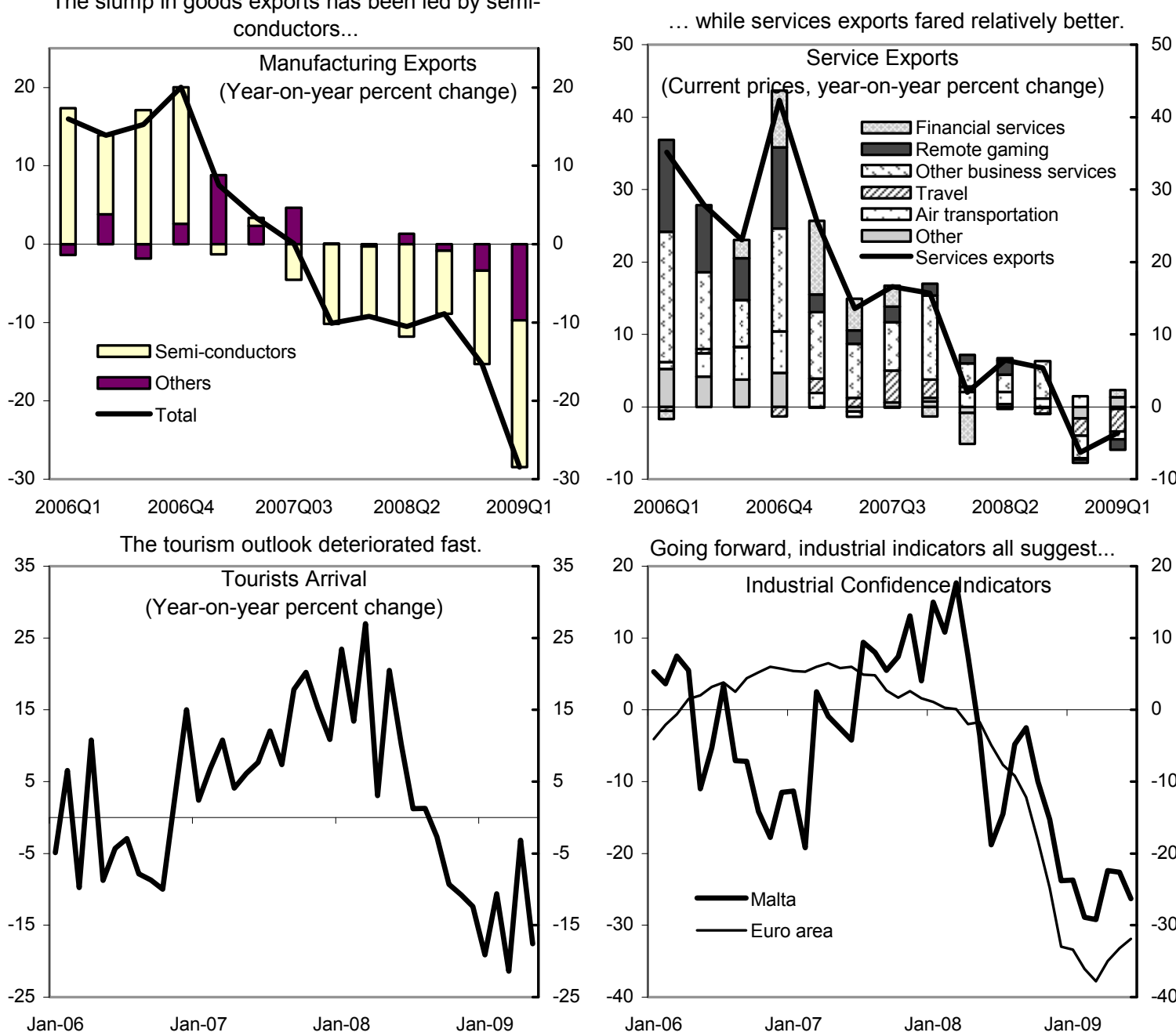

... a further contraction of production in 2009 ...

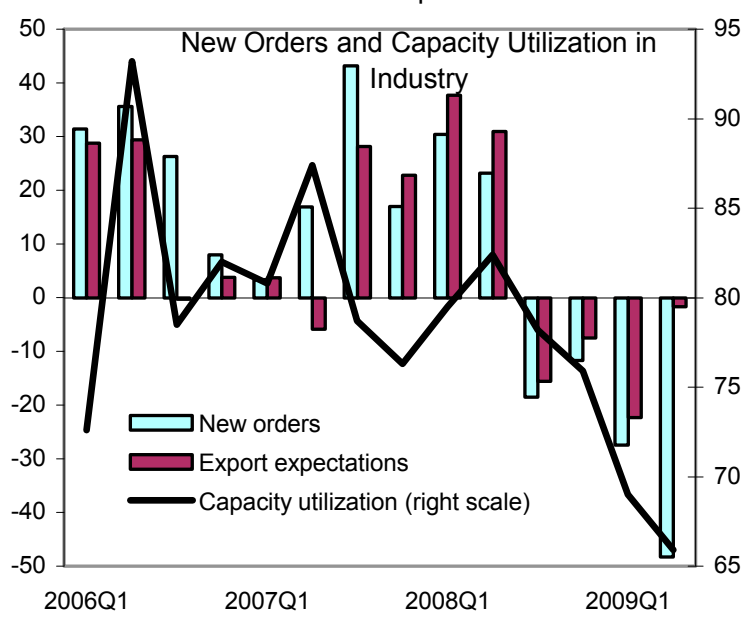

... while households' prospects, though more

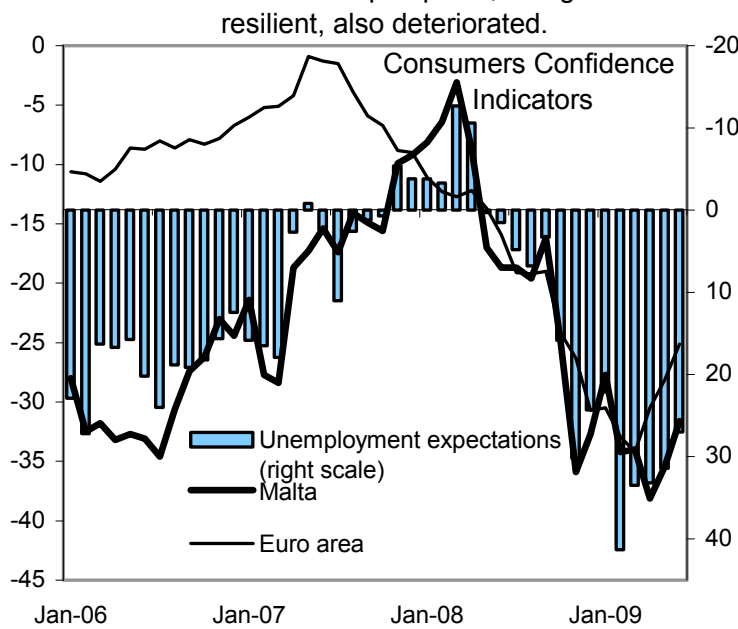

Sources: National Statistics Office; Central Bank of Malta; European Commission; and IMF staff calculations. 
Figure 3. Malta: Labor Market Indicators, 2000-2009

Labor market conditions remained tight in $2008, \ldots$

..the manufacturing sector continued shedding jobs,...
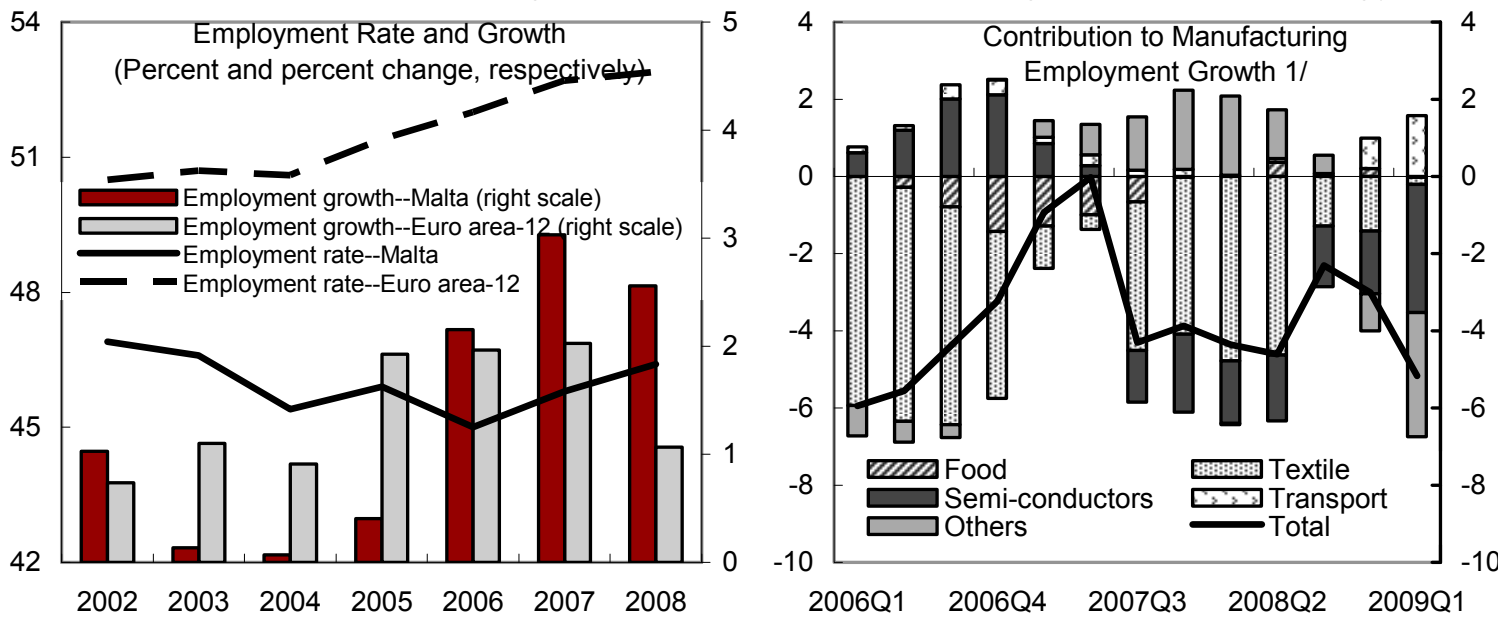

...and productivity gains vanished.

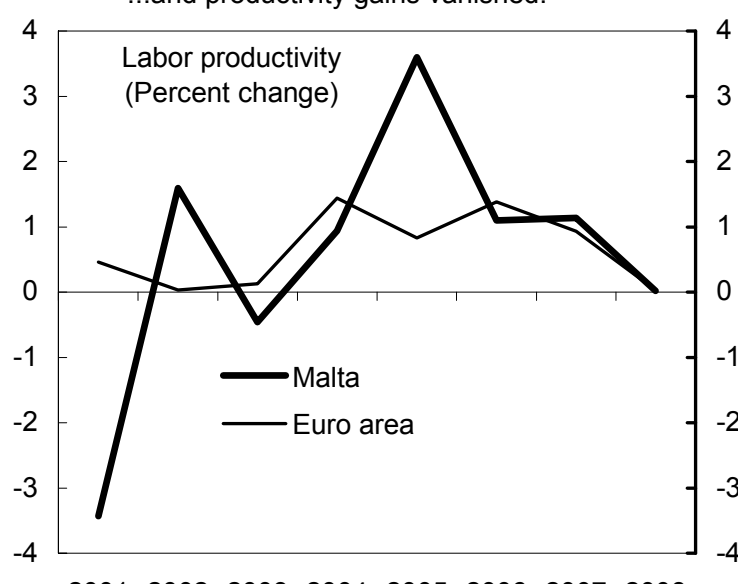

Still, wage development remained relatively moderate.

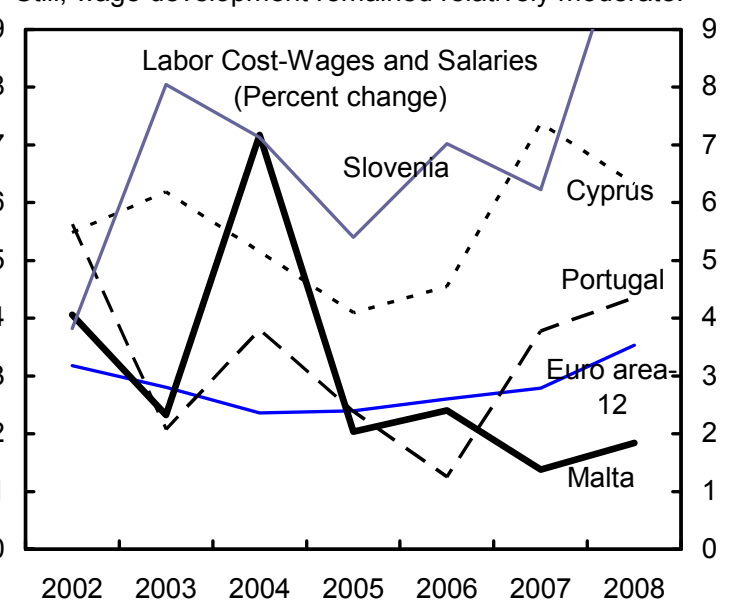

As the economic environment deteriorated in 2008 the unemployment rate inched up.

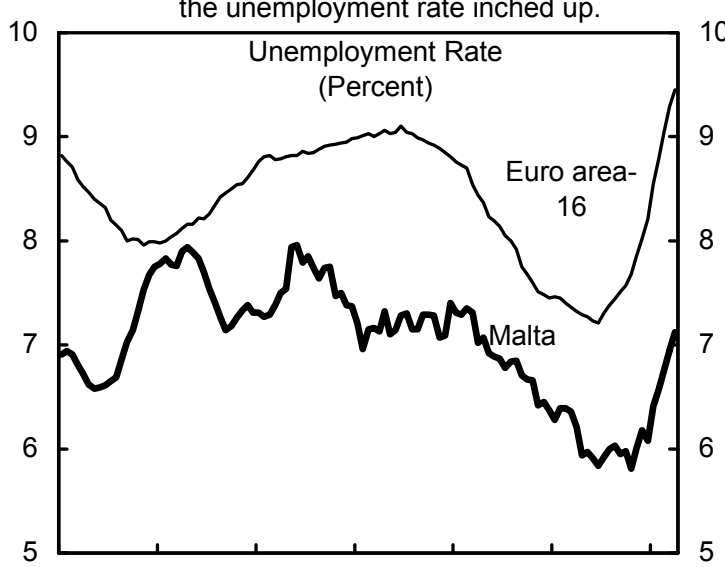

The female employment rate remains endemically low.

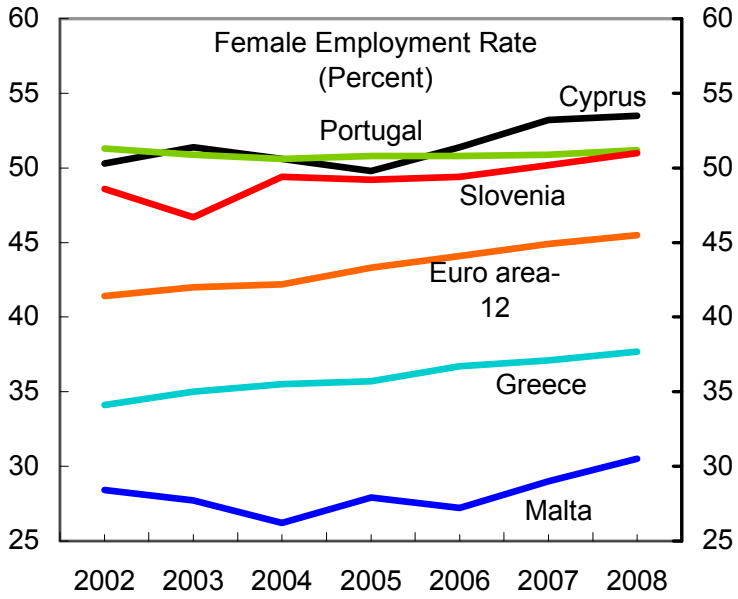

Jan-00 Jul-01 Jan-03 Jul-04 Jan-06 Jul-07 Jan-09

Sources: Eurostat; National Statistics Office; European Central Bank; World Economic Outlook; and IMF staff calculations.

1/ Year-on-year percent change. 
Figure 4. Malta: Inflation, 2001-2009

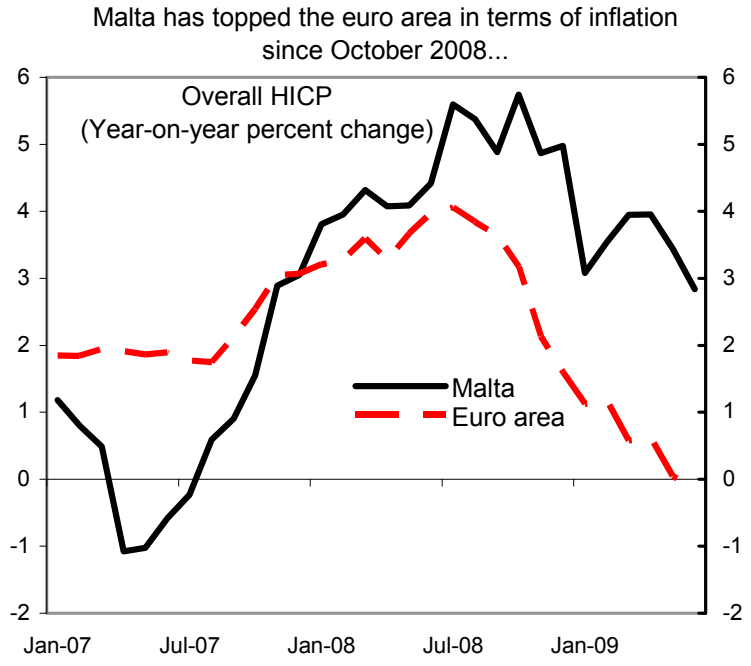

The decline in commodity prices was not passed on to food prices, ...

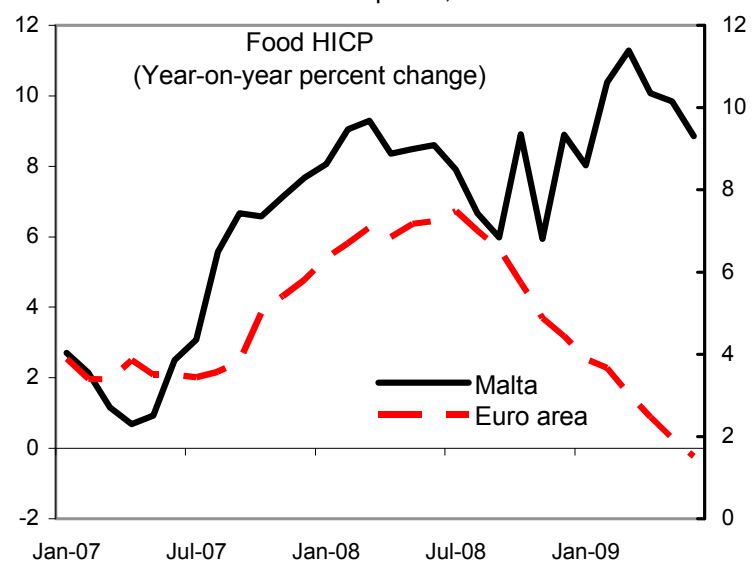

...while hospitality price moderation disappeared in 2008.

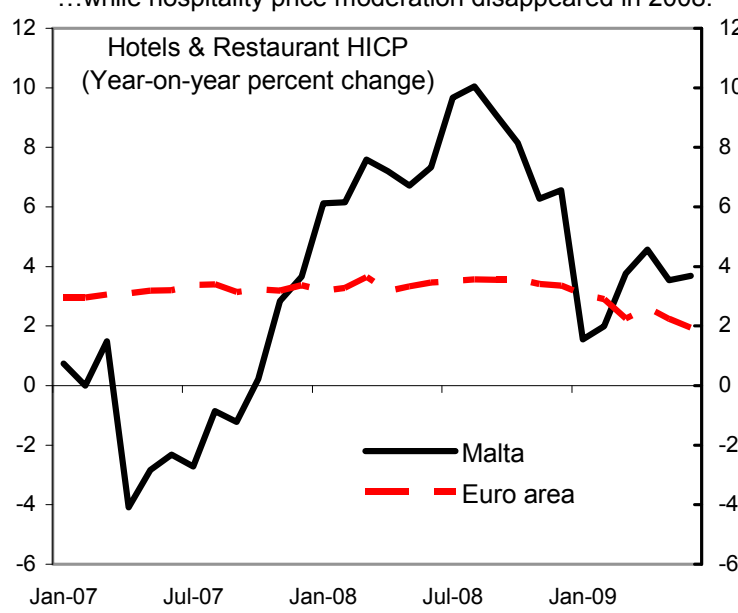

as food, energy, and hotel prices remained buoyant:

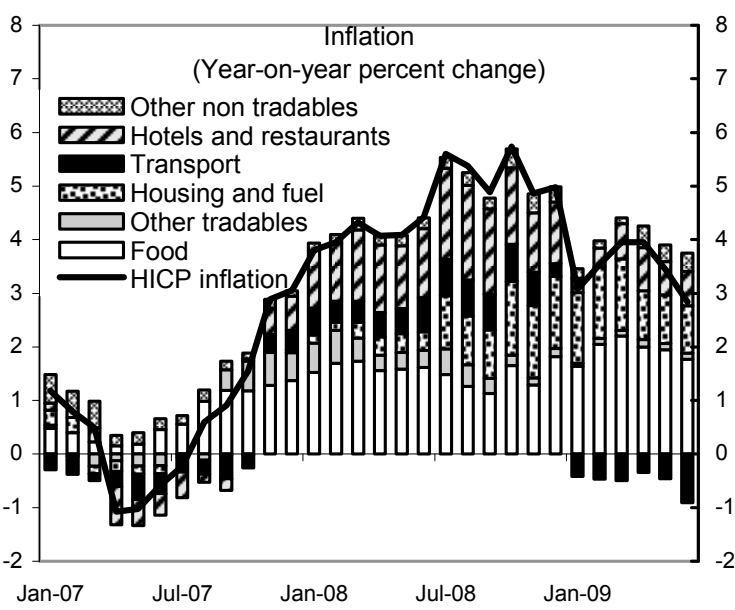

... the increase in administered utility prices kept energy inflation high,...

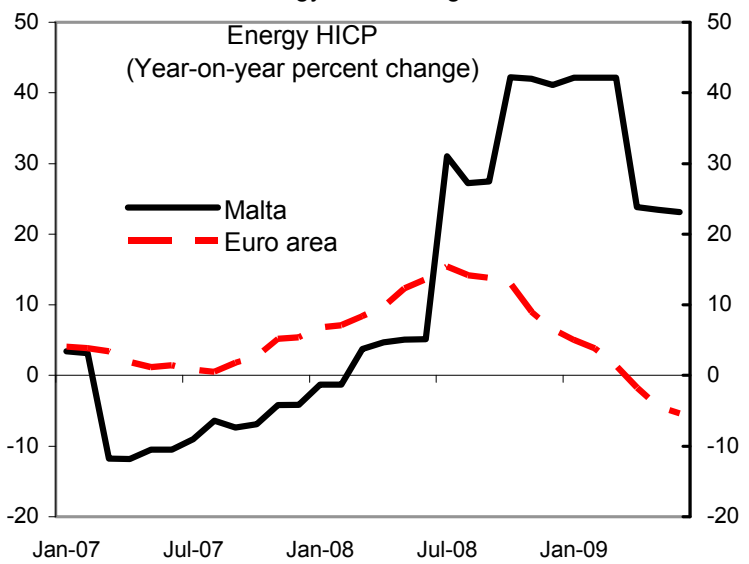

Housing prices experienced a downward correction.

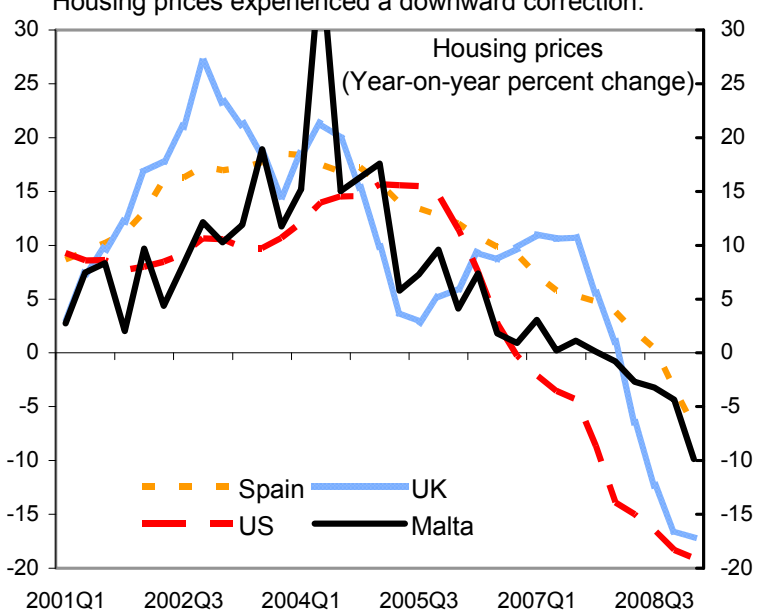

Sources: Eurostat; Central Bank of Malta; Global Insight; Standard\&Poor's; and IMF staff calculations. 


\section{Box - Inflation}

Inflation in Malta has been the highest in the euro area since October 2008. While inflation has trended downward in the euro area since mid-2008, prices continued accelerating in Malta until recently. This development followed a period from mid-2006 to end-2007, when conversely, inflation was more moderate in Malta than in the euro area.


The inflation differential with the euro area has been particularly marked for food, fuel and hospitality prices, related to idiosyncratic developments on the island:

- Utility services are governed by administered prices. Throughout 2007 and until October 2008, the authorities postponed the adjustment of these prices to oil prices hikes on the global markets, keeping energy prices artificially low in Malta. However, in the fall of 2008, prices were adjusted up, contributing to the build-up in the inflation differential as the euro area, conversely, was then starting to experience a deceleration in energy prices. With the authorities adjusting utility prices down again in April 2009, the discrepancy with the euro area in energy price inflation is expected to fade in the near future.

- Hospitality price moderation throughout 2007 reversed in 2008, as new high scale hotels opened up and tourism picked up, following the arrival of low-cost airlines. These price fluctuations were magnified by the relatively large share of this segment in the price basket, at 17 percent against 9 percent in the euro area. Looking forward, with tourism prospects rapidly deteriorating, price moderation is likely to resume.

- Food prices remained surprisingly buoyant in 2008 despite the generalized downward correction in global food commodity prices. Importers and domestic retailers failed to pass though this decline, possibly highlighting a lack of competition in the market. 


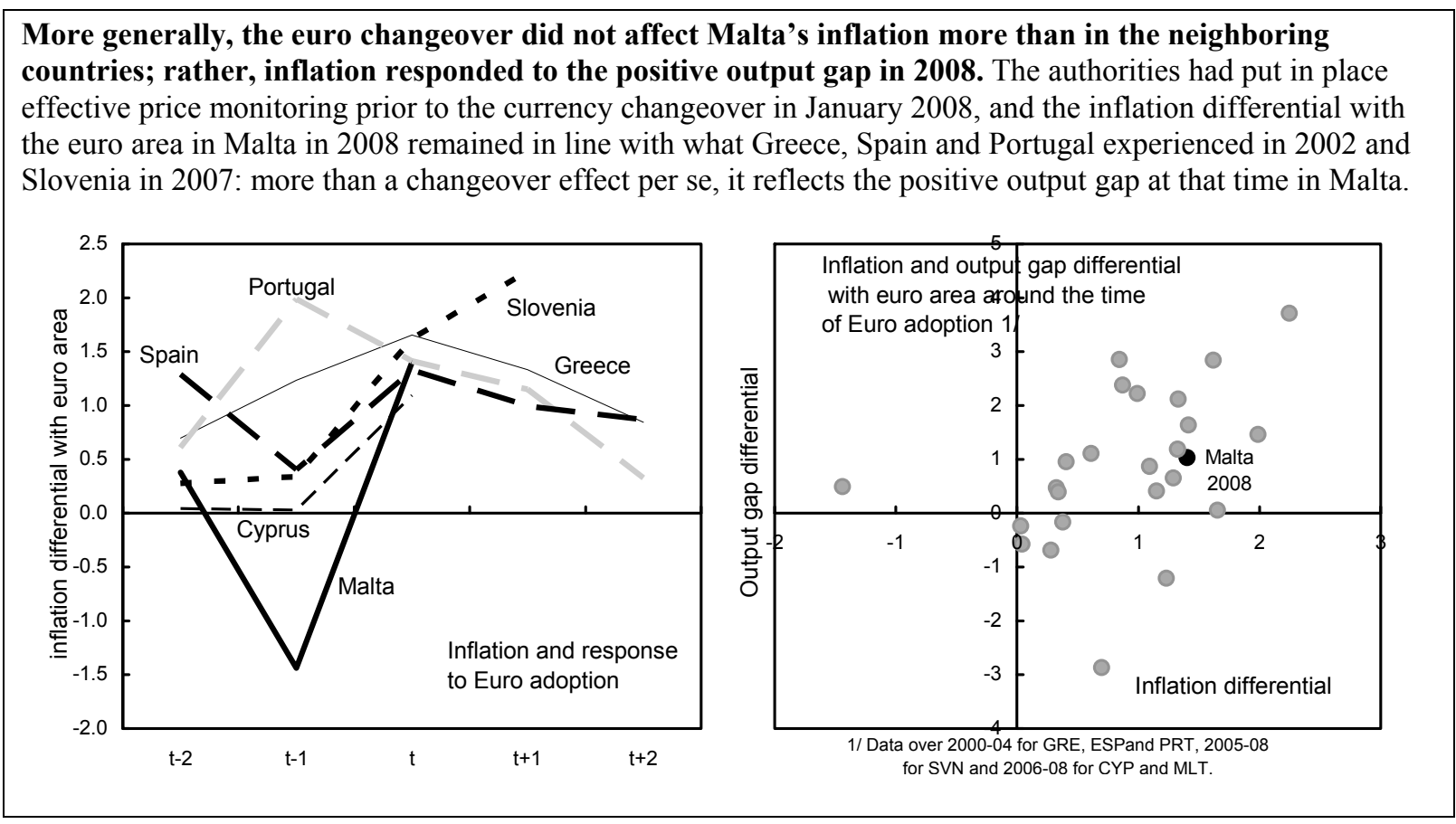

5. Fiscal consolidation came to a halt in 2008. The fiscal deficit reached 4.6 percent of GDP, after 2.2 percent in 2007, as the government took over the shipyards' operations ahead of their ongoing liquidation and financed early retirement schemes-accounting altogether for close to $1 \frac{1}{4}$ percentage points of GDP of deficit (Table 2 and Figure 5). Nevertheless, the structural relaxation amounted to 1 percent of

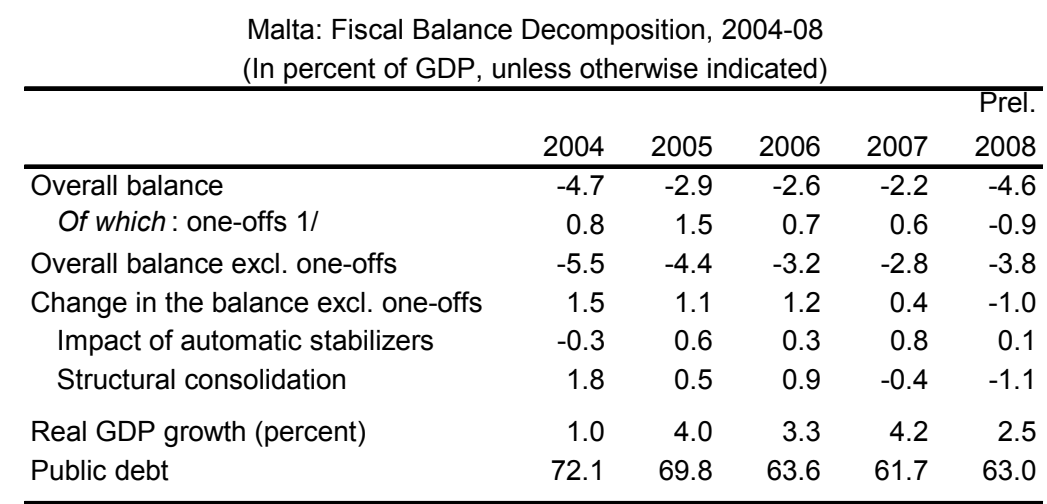

Sources: Eurostat; Malta's authorities; and IMF staff estimates.

$1 /$ One-offs include revenue from proceeds of property sale in 2004-08 in addition to a tax amnesty in 2007 , the shipyards' restructuring costs and reclassification as part of the general government in 2008 .

GDP because of larger energy subsidies in the context of rising oil prices in the first half of the year and significant slippage on the wage bill and on spending on goods and services, partly related to the health care sector and to the elections in March 2008. Reversing the downward trend, public debt inched up to 63 percent of GDP and the sovereign spread vis-à-vis the German 10-year bond rose in line with regional peers, to reach about 110 basis points in May 2009. So far, the authorities have managed to finance the deficit without difficulties. Owing to the fiscal slippages, the European Commission reinitiated the excessive deficit procedure for Malta in May 2009 and recommended to bring the deficit below the Maastricht reference value by 2010. 
Figure 5. Malta: Fiscal Sector, 2003-2014

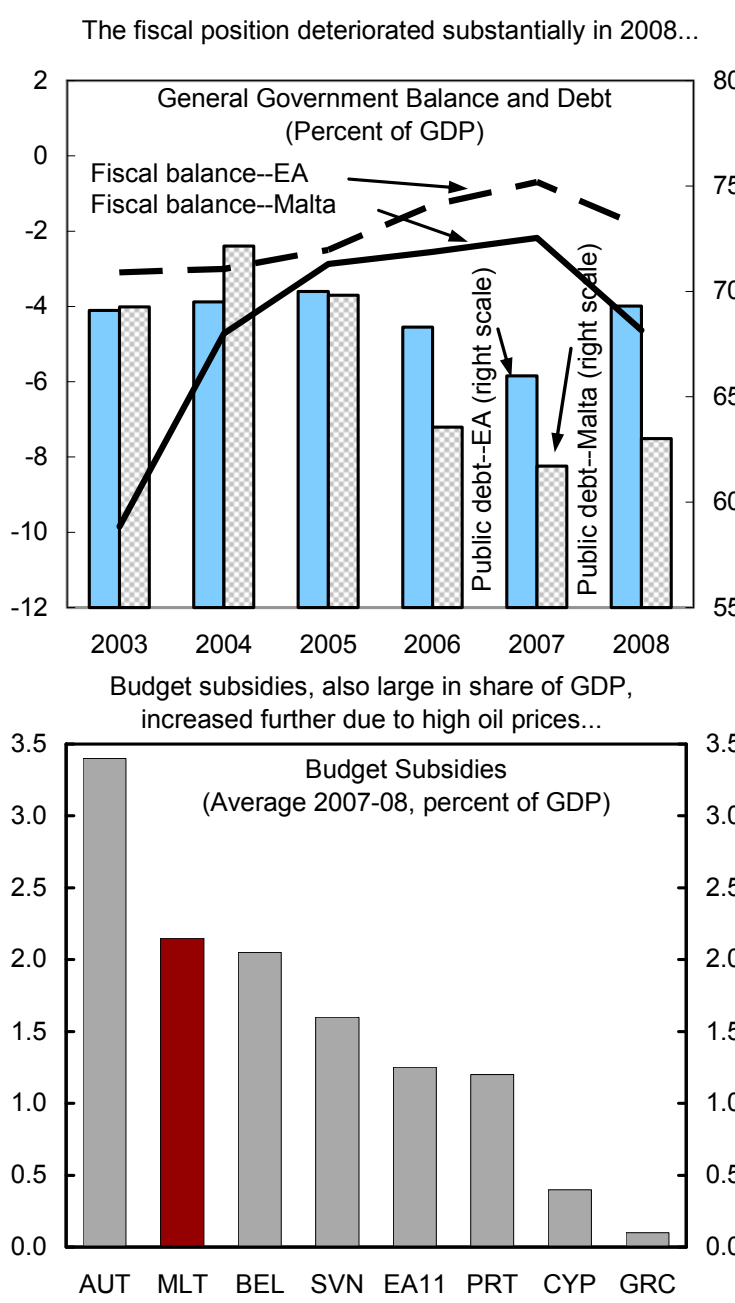

Expenditure-based consolidation needs to resume in

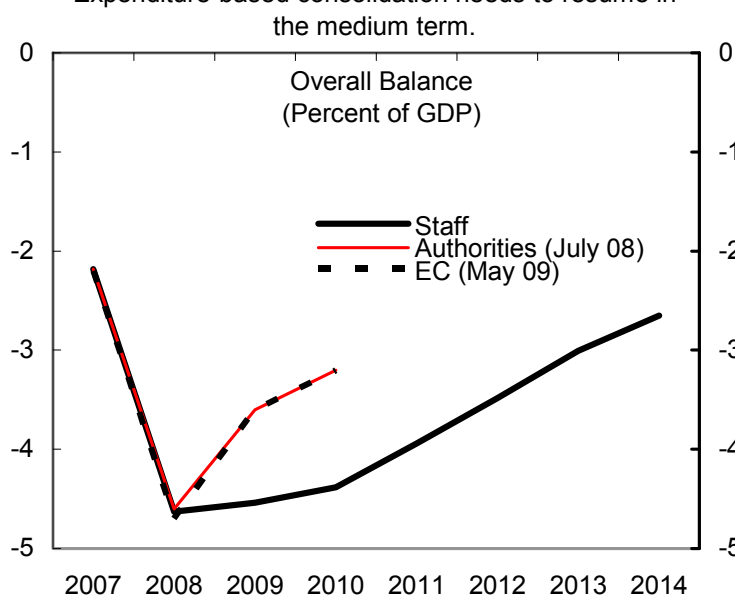

...led by slippages in the wage bill, already high by euro area standard.

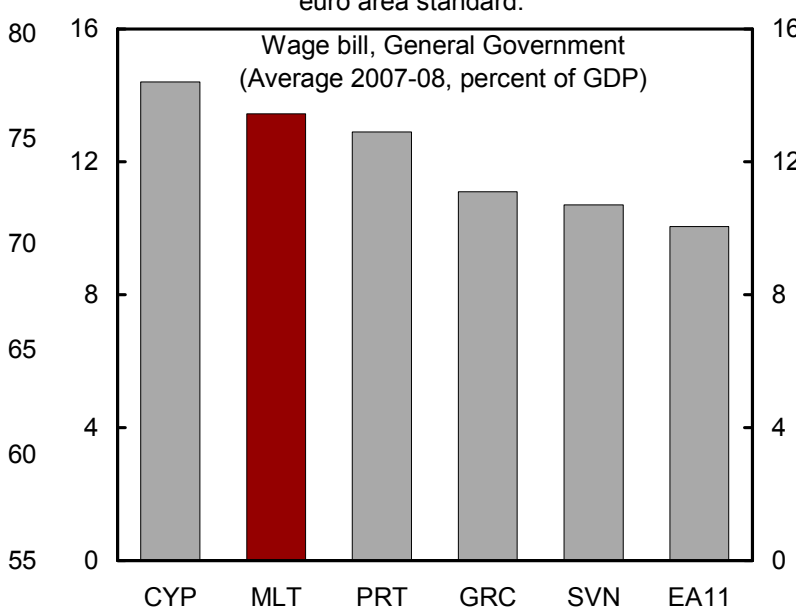

...while state aid dropped significantly as a result of Malta Shipyards' restructuring.

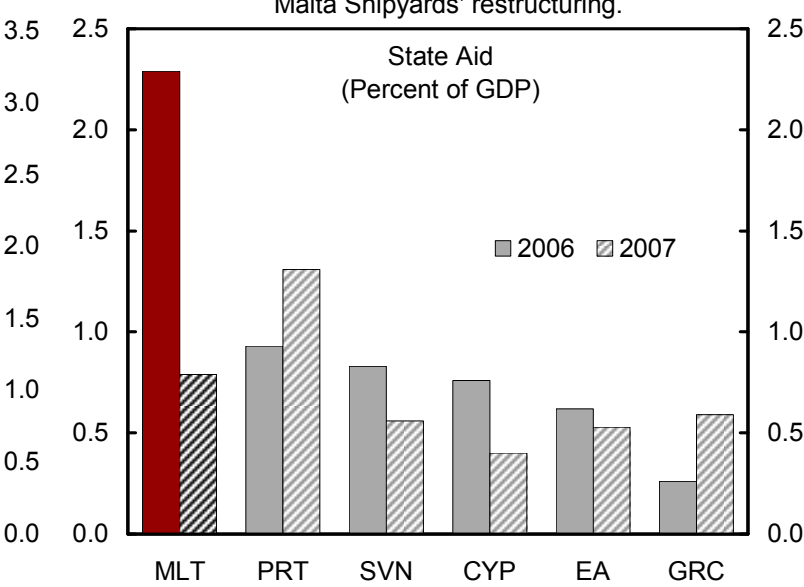

Pension spending is increasing, with a total bugdetary impact of ageing well above the euro area average.

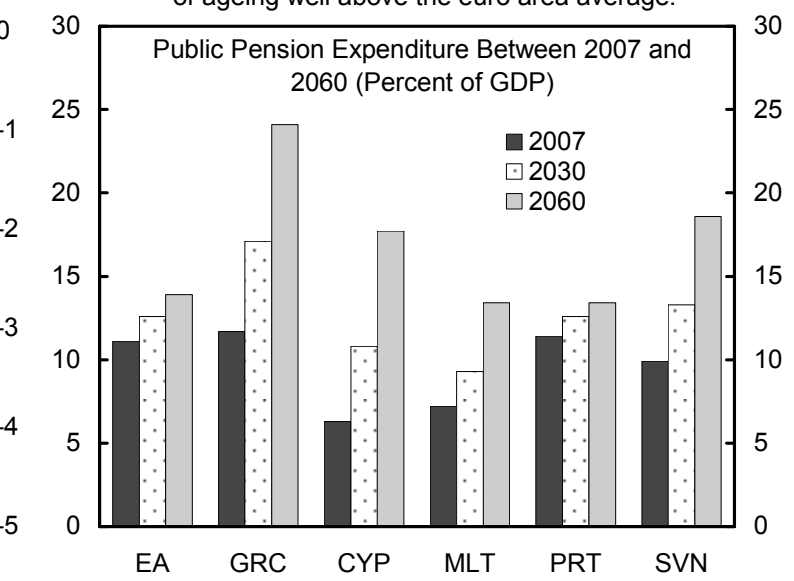

Sources: Eurostat; European Commission; Maltese Authorities; and IMF staff estimates. 
6. The authorities passed a stimulus package in the $\mathbf{2 0 0 9}$ budget. Measures include support to the manufacturing and tourism sectors, as well as increased public investment financed through higher EU fund absorption. The personal income tax regime was also modified to increase incentives to work, in particular for women. The overall package amounts to $1 \frac{1}{2}$ percent of GDP, two thirds of which would be financed by EU grants. Since early 2009 , the authorities have also provided additional support to a small number of ailing manufacturing companies based on criteria related to investment and training plans.

\section{The impact of the financial market turmoil on Maltese banks has so far} remained contained (Figure 6, Appendix). The banking sector has expanded rapidly in recent years to over seven times GDP; most of this growth, however, has been driven by internationally oriented banks with traditionally little interaction with the domestic economy. ${ }^{2}$ Still, domestically oriented banks have been protected in the crisis by their limited exposure to structured financial products, a traditional retail funding model, and conservative lending policies. Credit has proved resilient, with loans to the resident private sector growing 10 percent in 2008, as banks continued to fund their operations mainly through domestic deposits. No government intervention to shore up capital or liquidity has been necessary to date. However, some institutions suffered large valuation losses on their security portfolio, resulting in negative returns in 2008. At around 50 percent of GDP, household indebtedness is below euro area average, but it has been trending up, and the share of nonperforming loans (NPL) remains high in domestically oriented banks.

\section{The current account deficit improved to $\mathbf{5} \frac{1}{2}$ percent of GDP in 2008 (Figure 7,}

Table 3). The goods balance worsened, as foreign demand faltered, most notably for semiconductors, whose export growth turned negative in nominal terms in the fall of 2007. Conversely, thanks to past efforts at export diversification, net services exports improved, led by business services and the remote gaming industry. Imports volumes slumped, as investment gradually dried up throughout 2008. Against this backdrop, competitiveness is deemed to have remained broadly stable. Moreover, the current account deficit continued to be more than financed by significant, yet declining, FDI net inflows. Portfolio and other investment flows remain heavily influenced by operations of internationally oriented banks.

\section{The reform-oriented Nationalist Party was reelected in March 2008 with a} narrow parliamentary majority. Nonetheless, with the economy in recession and euro membership secured, the government's immediate priority has shifted from liberalizing initiatives and fiscal consolidation to measures to support the economy.

\footnotetext{
${ }^{2}$ Out of 23 banks, 13 are locally incorporated subsidiaries of foreign institutions and three are foreign branches. Only seven banks, dubbed domestically oriented banks - accounting for 30 percent of total assets - play a role in domestic intermediation. Most of the remaining 16 internationally oriented banks, settled in Malta for tax optimization purposes, use funding from their overseas banking groups to finance assets outside Malta.
} 
Figure 6. Malta: Financial Indicators, 2005-2009

The stock market fell along with euro area index...

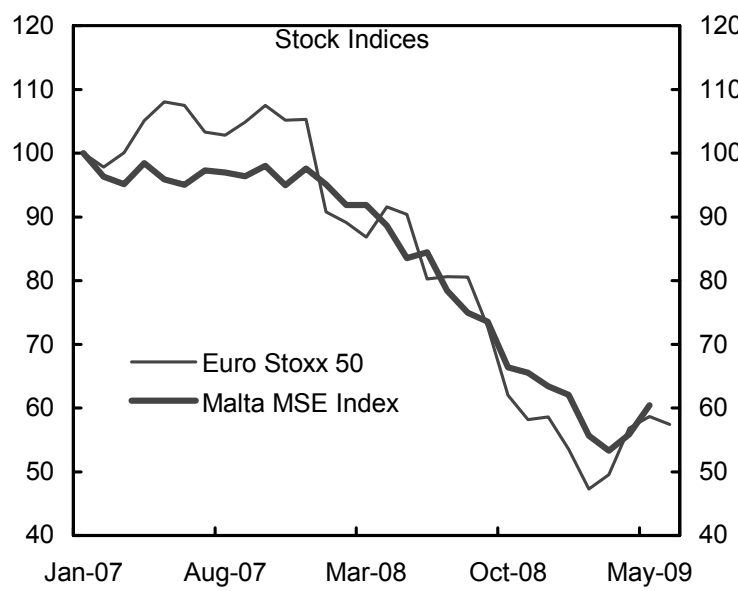

Sovereign yields have increased in line with those of the region...
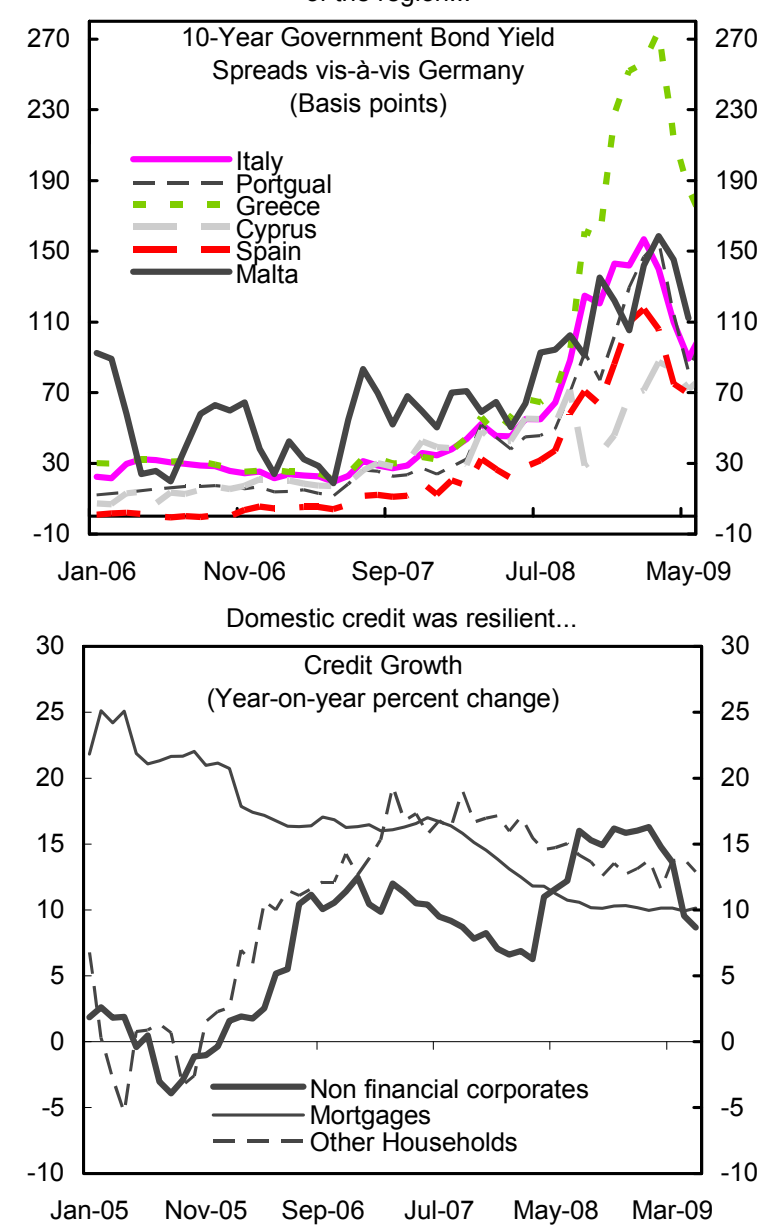

.and Malta's main two domestic banks' equity valuations.
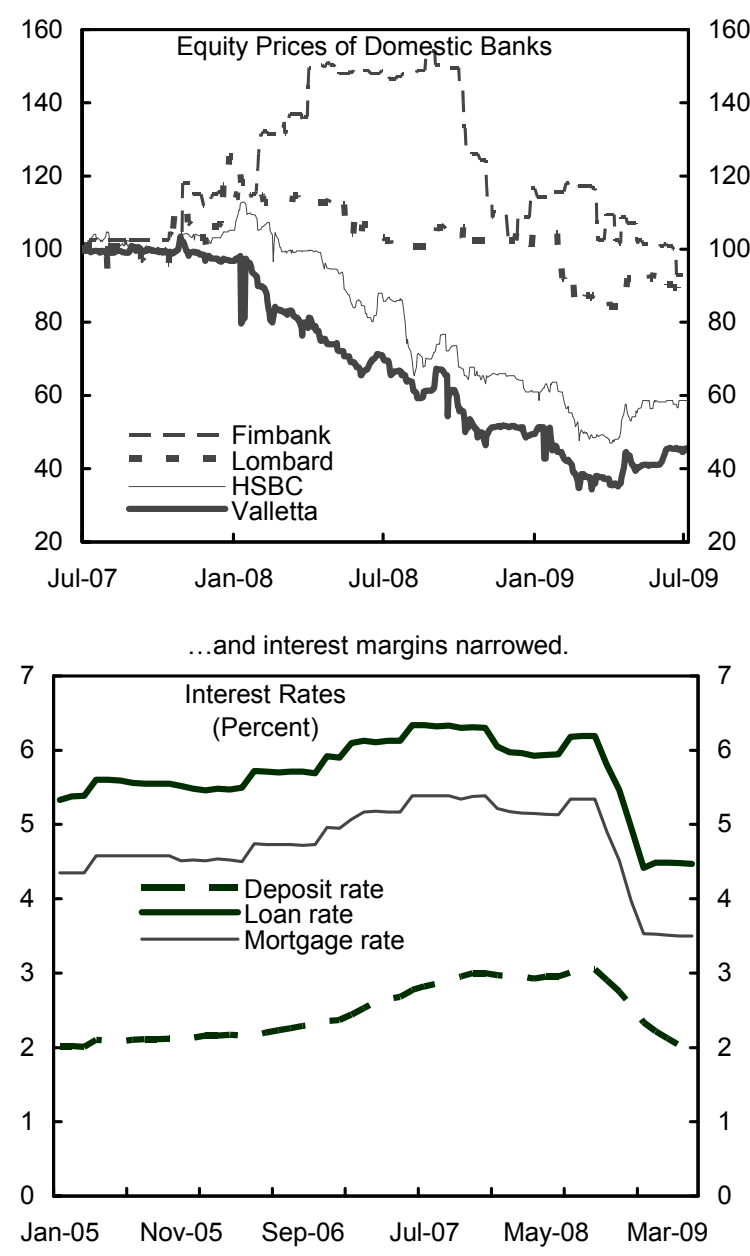

....and Maltese private agents are not overly leveraged.

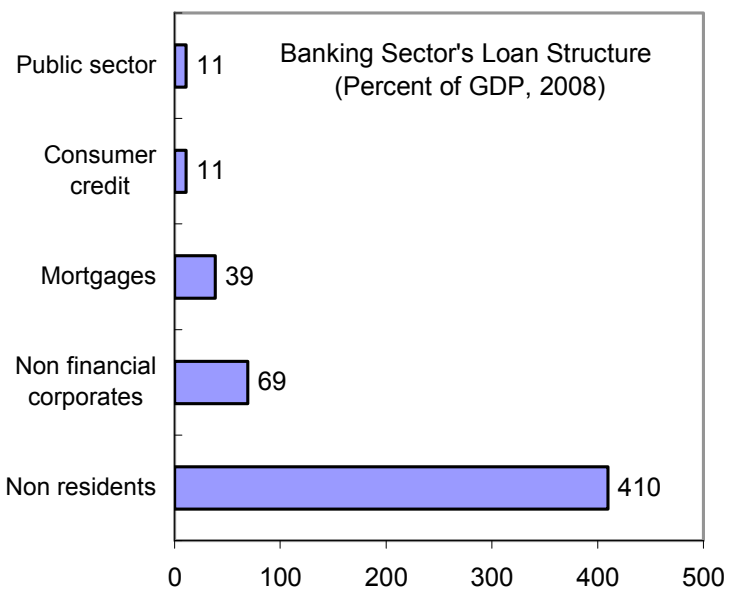

Sources: Bloomberg; Eurostat; Central Bank of Malta; and IMF staff calculations. 
Figure 7. Malta: External Sector, 2000-2008

While the current account deficit narrowed in 2008

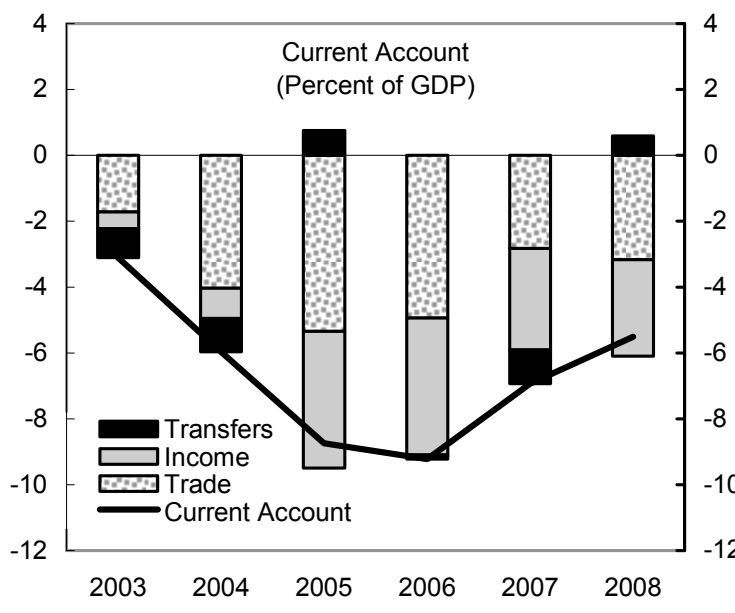

Traditional goods exports continued shrinking...

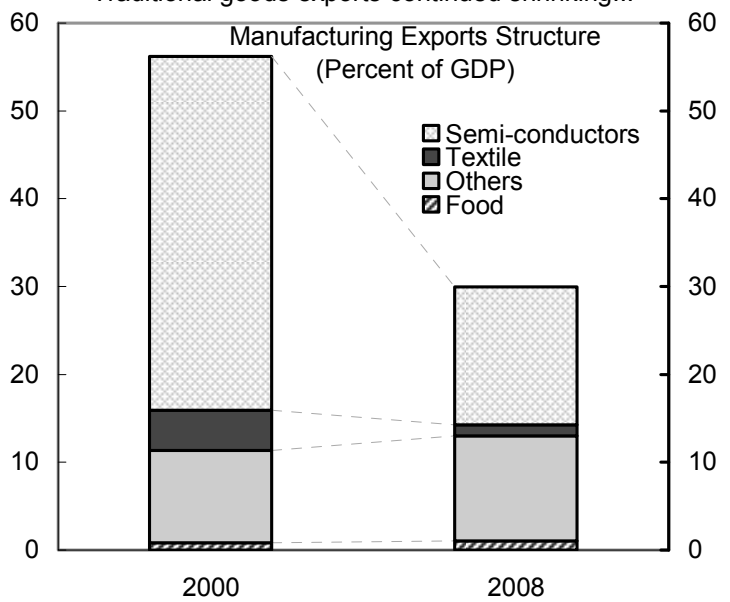

Yet, activity is being diversified towards higher valueadded services exports..

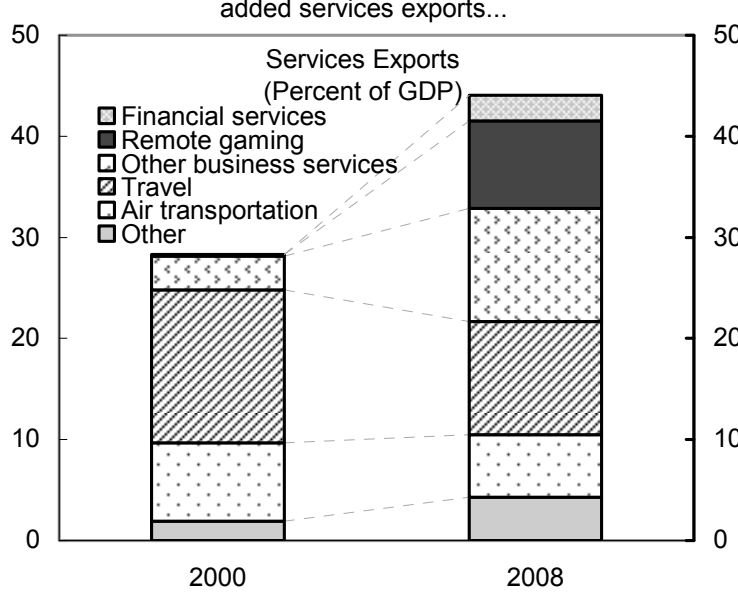

...the trade balance deteriorated slightly.

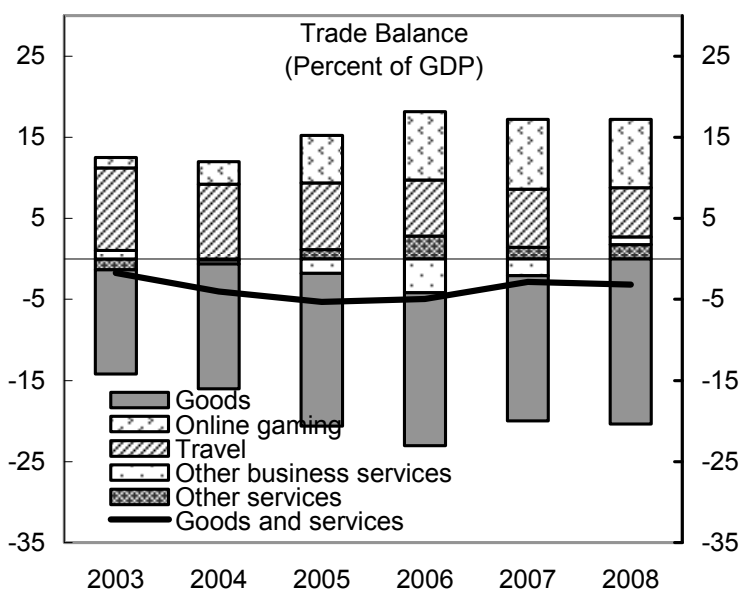

...leading to a further decline in goods trade share.

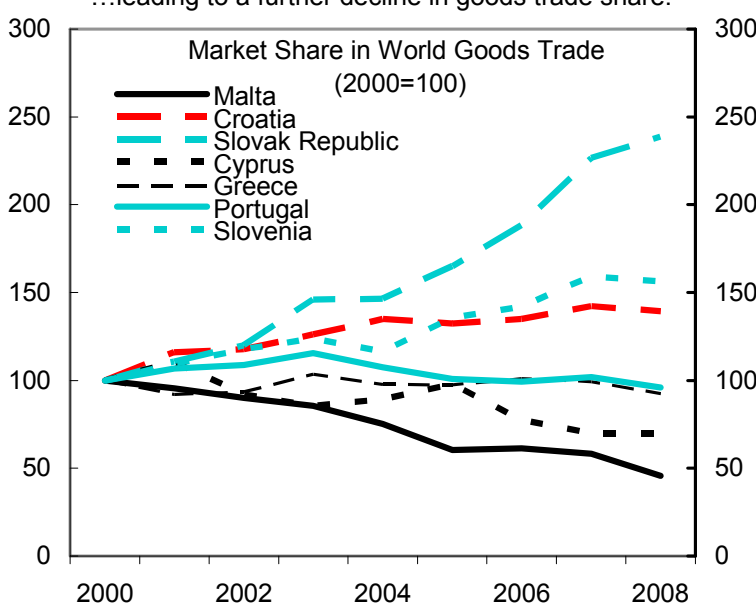

... allowing Malta to preserve its ToT position.

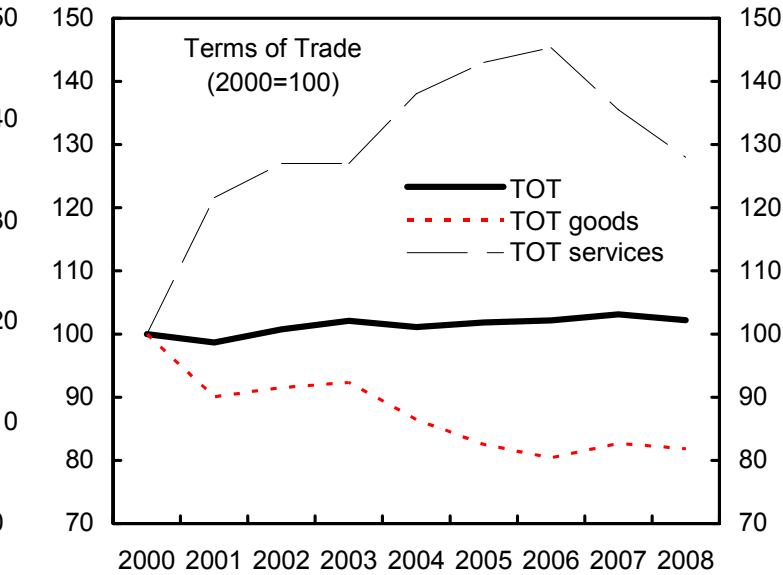

Sources: Central Bank of Malta; Eurostat; IMF, Direction of Trade Statistics; and IMF staff calculations. 


\section{OUTLOOK}

\section{With recession affecting all main trade partners, growth in Malta is projected}

to turn negative in 2009. Staff projects activity to contract by about 2 percent in 2009, with the output gap turning negative and remaining so until 2014. As foreshadowed by the most recent confidence indicators, all private components of demand - exports, private investment and households' consumptionwould drive the slowdown in 2009. Higher public infrastructure spending and, to some extent, resilient activity in services, are expected to cushion the slowdown. A modest recovery, of about $1 / 2$ percent, is projected for 2010 , as exports pick up in line with trade partners' growth, prompting a gradual revival in private investment and labor market conditions. The authorities concurred with staff that, in the context of the global crisis,

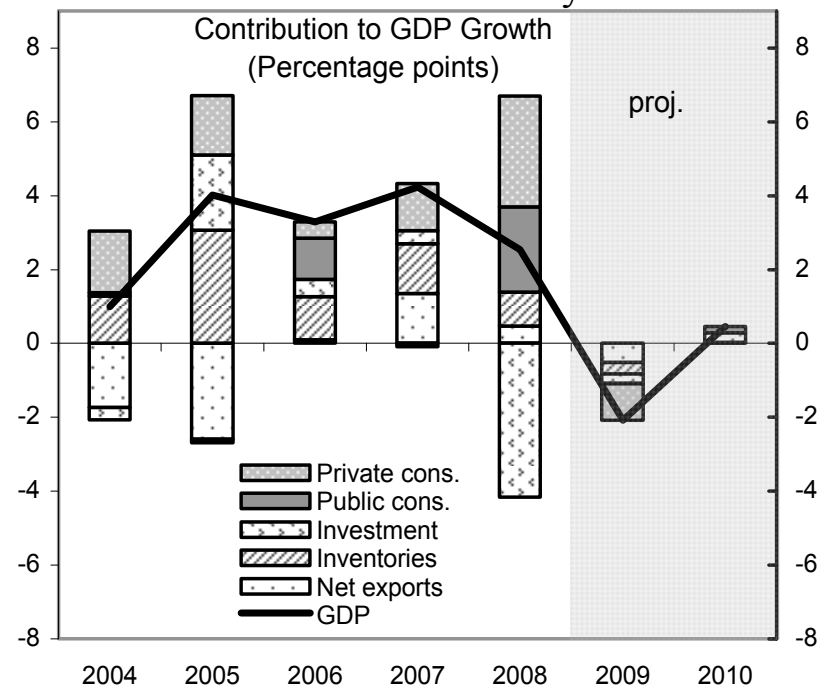
potential growth would soften going forward.

\section{Inflation is projected to moderate while the current account deficit would} stabilize, with long-term sustainability risks mitigated by the positive net international investment position. With the output gap turning negative and world commodity prices lower, inflation would fall to $23 / 4$ percent in 2009 from $43 / 4$ percent in 2008 , and the current account deficit would stabilize at 53/4 percent of GDP. Staff's external sustainability analysis points to a strengthening in the net external creditor position as net FDI inflows would continue to more than finance the external deficit (Tables 4 and 5). Nonetheless, gross external liabilities stood at over 550 percent of GDP at end-2008, owing to strong growth in recent years in nonresident deposits held by internationally oriented banks; while these are backed by matching assets, the associated external vulnerability reinforces the need for fiscal and financial buffers to anchor investors' confidence in Malta's small open economy.

12. Staff sees clear risks to the recovery in 2010. First, it is conditional on a gradual improvement in trade partners' growth, which could fail to materialize. Risks also stem from potentially tighter credit conditions, as the economic slowdown inevitably leads to a deterioration in banks' asset quality. Finally, in a context of more depressed global demand, the revival in activity could be further jeopardized if the strategy of export diversification were to falter for lack of foreign investor appetite. Risks to inflation are more balanced: persistent food price increases could continue to spur inflation, at least temporarily; conversely, a more severe slowdown in activity, especially for export-oriented sectors, could put downward pressures on prices. 
13. The authorities' outlook is more benign. In particular, they saw private consumption remaining more resilient, supported by wage and credit growth, and forecast a stronger pick up in corporate investment going forward. However, they agreed with staff that risks were on the downside and acknowledged that some downward adjustment to their projection could not be excluded as further macroeconomic updates came in.

\section{Policy discussions}

\section{While responding to the crisis has become the authorities' top priority, the} structural reform agenda will need to regain preeminence. Key elements include: resuming fiscal consolidation once the recovery is established to build buffers against future external shocks and as the population ages; further strengthening the financial supervisory framework to keep up with the rapidly expanding sector; and completing the labor and product market reforms so as to further the move towards higher value-added activities.

\section{A. Preserving Fiscal Sustainability In A Recession}

\section{The fiscal deficit is expected to narrow marginally to $4 \frac{1}{2}$ percent of GDP in}

2009. However, excluding the substantial one-offs of 2008 , the balance would deteriorate by over $1 / 2$ percentage point of GDP. Slippages, in particular on utility subsidies, contributed to the fiscal relaxation in 2008; the authorities have curtailed them, and the structural consolidation for 2009 is projected to reach $3 / 4$ percentage point of GDP. Still, the authorities are letting automatic stabilizers play in full, providing support to domestic demand of about $1 \frac{1}{2}$ percentage points of GDP. In addition, staff estimates that EU funding of the stimulus measures would represent $1 / 2$ percent of GDP of additional support to demand. Based on somewhat stronger real growth forecasts, the authorities' fiscal projections are more optimistic, with a decline in the deficit of 1 percentage point compared to 2008, underpinned primarily by higher assumption of direct tax collection.

\begin{tabular}{|c|c|c|c|c|c|c|c|}
\hline \multicolumn{8}{|c|}{$\begin{array}{l}\text { Malta: Medium-Tem Fiscal Projections, } 2008-14 \\
\text { (In percent of GDP, unless otherwise indicated) }\end{array}$} \\
\hline & \multirow{2}{*}{$\begin{array}{l}\text { Prel. } \\
2008\end{array}$} & \multicolumn{6}{|c|}{ Proj. } \\
\hline & & 2009 & 2010 & 2011 & 2012 & 2013 & 2014 \\
\hline Overall balance & -4.6 & -4.5 & -4.4 & -3.9 & -3.5 & -3.0 & -2.6 \\
\hline Of which : one-offs $1 /$ & -0.9 & -0.1 & 0.1 & 0.1 & 0.0 & 0.0 & 0.0 \\
\hline Overall balance excl. one-offs & -3.8 & -4.4 & -4.5 & -4.0 & -3.5 & -3.0 & -2.6 \\
\hline Change in the balance excl. one-offs & -1.0 & -0.7 & 0.0 & 0.4 & 0.6 & 0.5 & 0.4 \\
\hline Impact of automatic stabilizers & 0.1 & -1.4 & -0.5 & 0.0 & 0.2 & 0.3 & 0.2 \\
\hline Structural consolidation 2/ & -1.1 & 0.7 & 0.4 & 0.4 & 0.3 & 0.2 & 0.1 \\
\hline Real primary expenditure growth (percent) 2/ & 2.4 & -2.9 & -0.5 & 1.0 & 1.7 & 1.7 & 2.4 \\
\hline Real GDP growth (percent) & 2.5 & -2.1 & 0.5 & 2.2 & 2.7 & 2.8 & 2.9 \\
\hline Public debt & 63.0 & 67.7 & 70.0 & 70.7 & 70.6 & 69.9 & 68.8 \\
\hline \multicolumn{8}{|c|}{ Memo items: authorities' projections (July 2009 pre-budget document) } \\
\hline Overall balance & -4.6 & -3.6 & -3.2 & & & & \\
\hline Real GDP growth (percent) & 2.5 & -0.9 & 0.2 & & & & \\
\hline
\end{tabular}

Sources: Malta's authorities; and IMF staff estimates.

1/ One-offs include revenue from proceeds of propertysale in 2008, the shipyards' restructuring costs in 2008-09, and the shipyards' reclassification as part of the general government in 2008.

2/ The projected consolidation in 2009 reflects the reversal of higher than budgeted energy subsidies in 2008 ( $1 / 2$ percent of GDP) and the impact of utility s ubsidies reform ( 0.3 percent of GDP). 


\section{Staff agreed with the thrust of the authorities' fiscal policy for 2009. The} economic downturn called for a fiscal response to support activity, and the focus on public investment in the 2009 stimulus package is apposite, given infrastructure needs and its potentially high multiplier. While letting the automatic stabilizers play fully, the authorities are making fiscal room by cutting inefficiently targeted subsidies on utilities. In addition, boosting EU fund absorption prevents an excessive deterioration in the public finances and current account. For 2010, staff recommended only moderate structural consolidation, to the tune of $1 / 2$ percentage point of GDP, so as not to jeopardize the modest recovery.

\section{Measures taken to support enterprises raise some concerns, however. The} measures implemented in the spring of 2009 to co-finance investment and training allowed for rapid and targeted support. Staff noted, however, that they could become entrenched and costly if the crisis continues, and that, in some cases, they might only postpone required restructuring. More recently, the authorities announced that they would tolerate late tax payments from companies with cash flow difficulties and also invited hotels and banks to work on debt restructuring. Staff underscored that, even if not widespread, these steps would risk undermining tax compliance and contract enforcement. The authorities agreed with the assessment but stressed that, given the small size of the economy and risk of spillovers, these measures had been necessary to shore up confidence.

\section{All concurred that fiscal consolidation needed to resume forcefully once the} recovery was established. The authorities are committed to consolidation and have taken significant steps with respect to the shipyards and the utility subsidies. However, staff stressed that these measures alone would fail to achieve the necessary consolidation: under an unchanged-policy scenario, the headline deficit would fall to the 3 percent mark only in 2013, with public debt topping 70 percent of GDP (Table 6). To secure a quick reversal in the debt trend and to build enough buffer against future shocks, a stronger consolidation path - with a structural effort of at least 2/3 percentage point of GDP per year over 20112014, more than double the current scenario - would be appropriate. Thus, staff urged the government to promptly identify commensurate underlying measures. The authorities
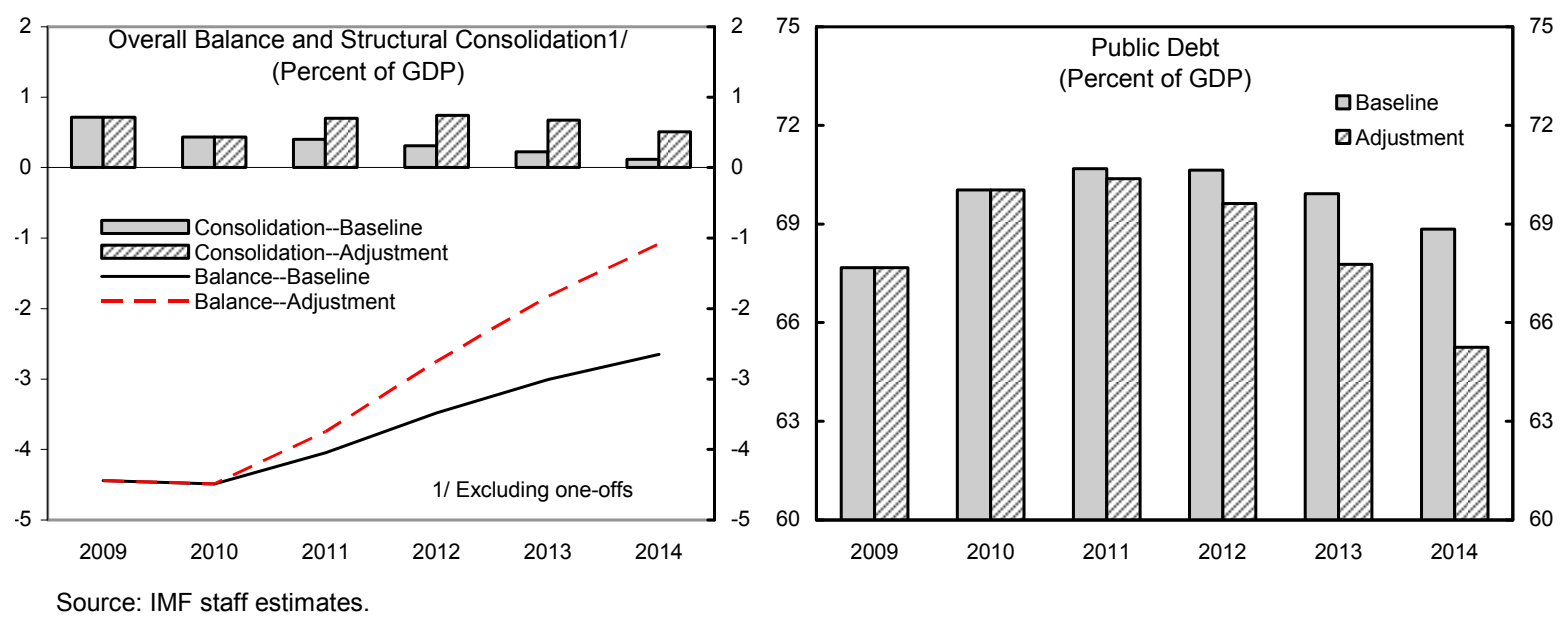
agreed that the adjustment should be essentially expenditure based, as increasing the tax burden, already around 40 percent, would run against their competitiveness strategy. Additional tax cuts should be implemented only as cost savings materialize and compliance improves.

19. Determined action on the expenditure side is required. The rigid spending structure - wages, transfers and interest payments account for more than two thirds of spending - hinders adjustment to shocks and crowds out capital outlays. Health care and education absorb about 30 percent of public spending and also stand out as areas needing rationalization. The authorities have so far relied on attrition to reduce public employment; staff called for a more proactive approach, based on a general review of public services needs to identify areas for retrenchment. Similarly, consideration should be given to market-based measures, both to provide incentives to rein in demand for public services and to increase the efficiency of supply. Streamlining social transfers and subsidies through broader means-testing of benefits will also be important. As an illustration, staff estimates that the adjustment scenario could be achieved with an annual real growth in primary current expenditure of $1 / 2$ percent over $2011-14$, as opposed to $1 \frac{3}{4}$ percent in the current scenario, with the wage bill growing at 1 percent versus 2 percent in the current scenario.

\section{Long-term projections reinforce the call for decisive consolidation and health} care reform. The EU-level Ageing Working Group's most recent estimates take into account the 2006 pension reform, which introduced an incremental increase in the retirement age, but also a partial indexation of benefits to wages. ${ }^{3}$ These estimates suggest that public spending on pensions would almost double in 2060 to reach $13 \frac{1}{2}$ percent of GDP - one of the highest percentage changes in the EU-27 — and that health care spending would sizably increase, too (Figure 5).

\section{Strengthening the fiscal framework will also be essential, in view of the} necessary consolidation. Despite the relatively good track record until 2007, recent spending slippages underscore the need to strengthen budget execution discipline, expenditure reporting and recording, and accountability. The authorities concurred and pointed to the initial steps undertaken to increase oversight of spending ministries. Staff also recommended informing fiscal projections with independent forecasts - possibly by expanding the mandate of the National Audit Office - and securing a stronger involvement of parliament, through medium-term targets committed to in the annual budget act and strengthened accountability of the government.

\footnotetext{
${ }^{3}$ See "The 2009 Ageing Report: Economic and Budgetary Projections for the EU-27 Member States (2008-2060)", Economic and Financial Affairs, European Commission.
} 


\section{B. Maintaining Financial Stability}

\section{Although Malta's banks have withstood the global financial turmoil reasonably} well so far, profitability is coming under pressure (Figure 8, Tables 7 and 8). Capital ratios, though declining, have remained well above regulatory minima. In addition, with a loan-to-deposit ratio at 80 percent at end-2008, domestically oriented banks have been protected from shocks in global wholesale markets by their reliance on deposits. However, as the global interbank market dried up, exposure of foreign-owned subsidiaries to their parent company increased sizably, and leverage rose. On the whole, vulnerabilities have increased in the wake of the financial turmoil, and the authorities agreed that profitability would remain under pressure from lower volumes, a narrowing in interest margins, and rising nonperforming loans as the economy weakens.

\section{Exposure to the real estate market appears to pose the main immediate risk.} Domestically oriented banks' activities are highly concentrated in the construction and real estate sectors - with related credit accounting for more than half of their loan portfolios - as well as in tourism and trade, increasing their vulnerability to the current contraction in global activity. Large single name exposures compound these risks. In addition, provisioning coverage is kept low by the extensive use of real estate collateral, further exposing them to the ongoing correction in housing prices. The authorities estimate that property prices might still be overvalued by up to 10 percent. Recent stress tests conducted by the central bank also highlight these vulnerabilities: in the event of a 30 percent drop in property prices, combined with a 15 percent increase in NPLs, a few banks would breach regulatory capital thresholds.

\section{The authorities agreed that a more proactive approach toward building buffers} was warranted. As the transmission channels of the global crisis continue to broaden, banks will need to build additional capital buffers well beyond statutory ratios, on top of expected requirements from Pillar II implementation. Institutions are aware of this, having successfully tapped the domestic market to raise capital recently; they should be encouraged to continue to take advantage of the current liquidity in Malta's financial market. Staff also recommended that the supervisor discuss with banks dividend payout policies and means to set provisions in a more proactive fashion, including through the introduction of tax deductibility for specific provisions, in line with international practice.

\section{Risks need to be better incorporated in the macro-prudential and supervisory}

framework. Univariate stress tests are regularly conducted by the central bank for 
Figure 8. Malta: Financial Soundness Indicators, 2008

(Percent)
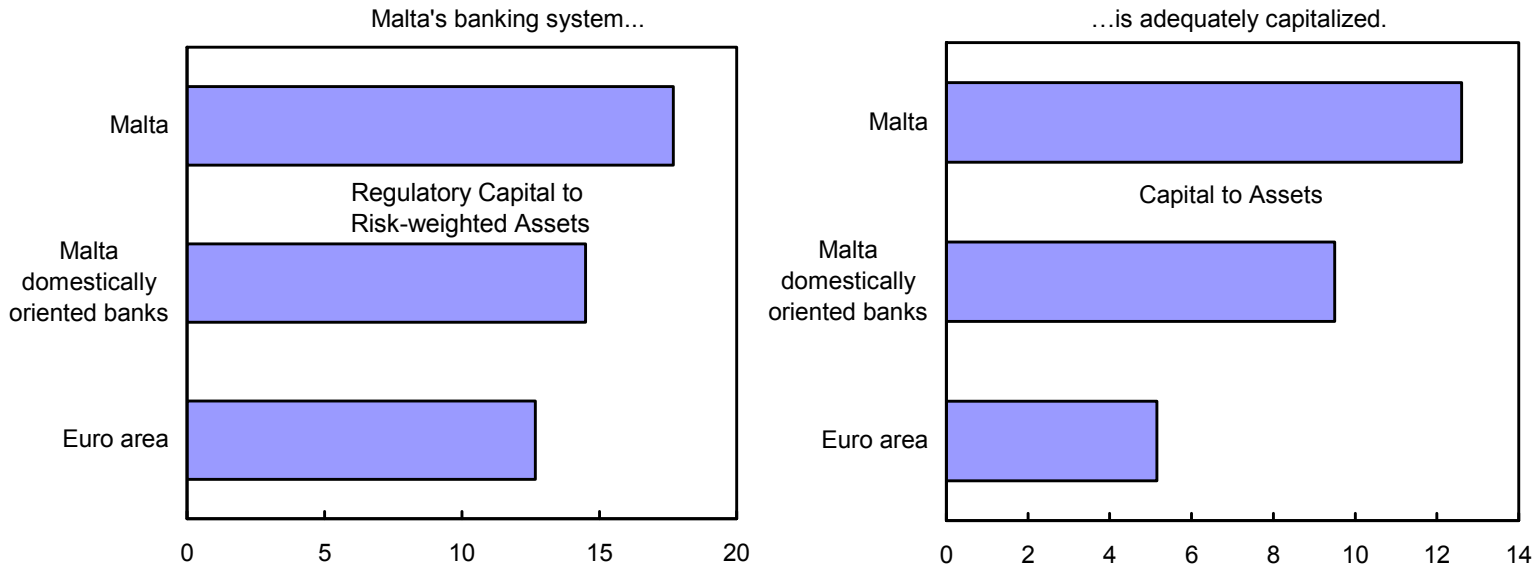

Profitability for the whole banking sector remains satisfactory...

...but it was affected negatively by valuation losses in domestically oriented banks.
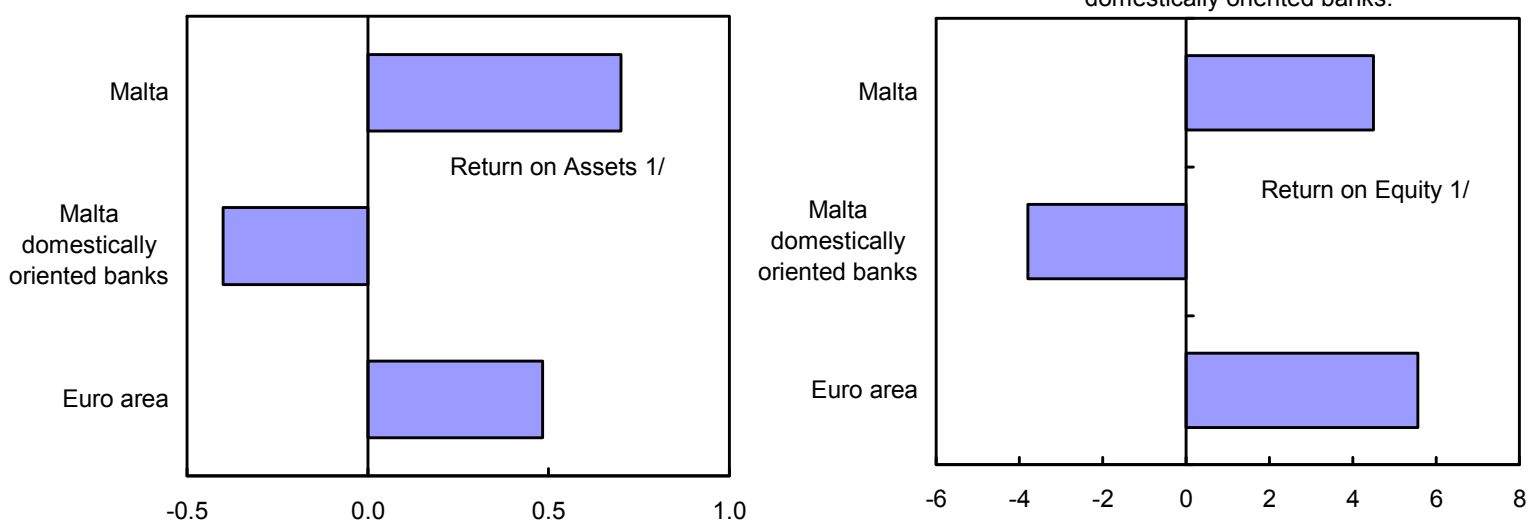

In addition, NPLs remain high by euro area standard in the domestically oriented banks..
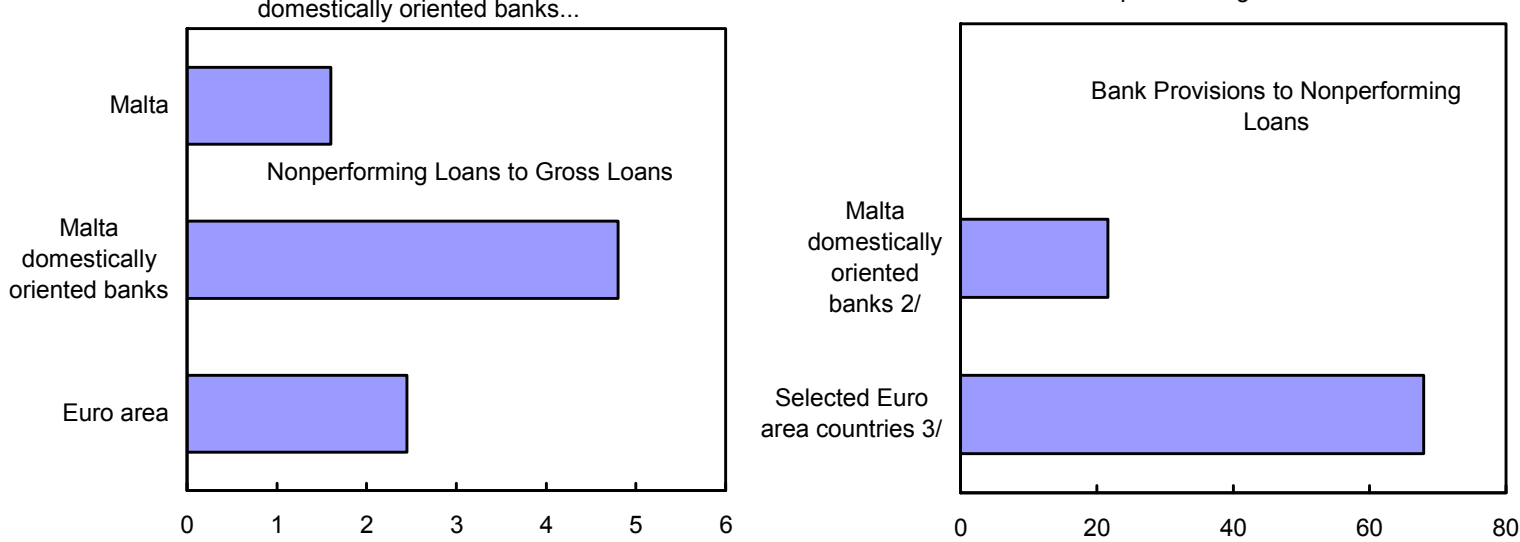

Sources:Global Financial Stability Report; Central Bank of Malta; and IMF staff calculations.

$1 /$ The negative value for domestically oriented banks is mostly attributable to one institution, which accounts for a relatively small proportion of total assets.

2/ As of March 2009.

3/ 2008 data are available for Belgium and Spain; a broader euro area average amounts to 86.1 percent for 2007. 
domestically oriented banks, but multivariate adverse scenarios need to be further tested. ${ }^{4}$ Similarly, while linkages between the internationally oriented banks and the domestic economy remain limited, they have been on the rise, as some institutions started participating in the domestic interbank market, issuing securities locally or collecting resident deposits. The central bank has accordingly gradually incorporated these institutions in its stability assessment and stress testing exercises, but systemic considerations still need to be better taken into account when setting prudential standards. To this end, the authorities intend to run a stress testing exercise involving the central bank, the supervisor and individual banks. Monitoring of large intragroup exposure risks should follow a similar template, in collaboration with home authorities. Alongside these efforts, regulatory scrutiny should be intensified to match the growing size and sophistication of the financial sector.

\section{The authorities would also need to further enhance their communication}

strategy and strengthen their crisis management framework. At the height of the global crisis, the government provided assurance that it stood ready to support banks and raised the level of deposit insurance substantially, in line with EU peers. Staff welcomed the recent publication of the financial stability report and stressed that, going forward, further regular communication to the public about the health of the financial sector would be critical. Similarly, closer monitoring of financial sector issues in the ministry of finance - as exemplified during the recently conducted crisis impact assessment-will be necessary. Finally, the authorities are undertaking legislative work to increase funding for the deposit guarantee scheme and to modernize their crisis management and bank resolution regime.

\section{Fostering Malta's Competitiveness}

\section{Against the backdrop of a trend shift in export structure towards higher value-added sectors, Malta's competitive position has remained broadly stable} (Figure 9). In recent years, strong FDI inflows, relatively subdued wage developments, and structural reforms underpinned the broadening of the tourism supply and the redeployment of activities toward new exports with higher value-added content, generating significant competitiveness gains. While

Estimates Applying the CGER Methodology to Malta

(Percentage difference between the actual REER and the estimated equilibrium REER) 1/

\begin{tabular}{lccc}
\hline & $\begin{array}{c}\text { Macroeconomic } \\
\text { Balance }\end{array}$ & $\begin{array}{c}\text { External } \\
\text { Stability }\end{array}$ & $\begin{array}{c}\text { Real Exchange } \\
\text { Rate }\end{array}$ \\
\hline $\begin{array}{l}\text { REER gap } \\
\text { Memo item: }\end{array}$ & 2.0 & 10.7 & 15.9 \\
2008 assessment & 3.2 & 7.5 & n.a. \\
\hline 1/ A positive result suggests an overvaluation. &
\end{tabular}

\footnotetext{
${ }^{4}$ The most recently published stress tests focused on risks related to asset quality (increase in probability of default from 10 to 20 percent), the economic downturn (increase in NPLs by 15 percent), the house price correction (increase in NPLs by 20 percent and decline in house prices by 30 percent), and liquidity (deposit withdrawals of 20 percent). While the tests showed that on average, the banking sector would still remain adequately capitalized, in some instances, some banks would fall below the regulatory thresholds.
} 
Figure 9. Malta: Cost Competitiveness Indicators, 2002-2008
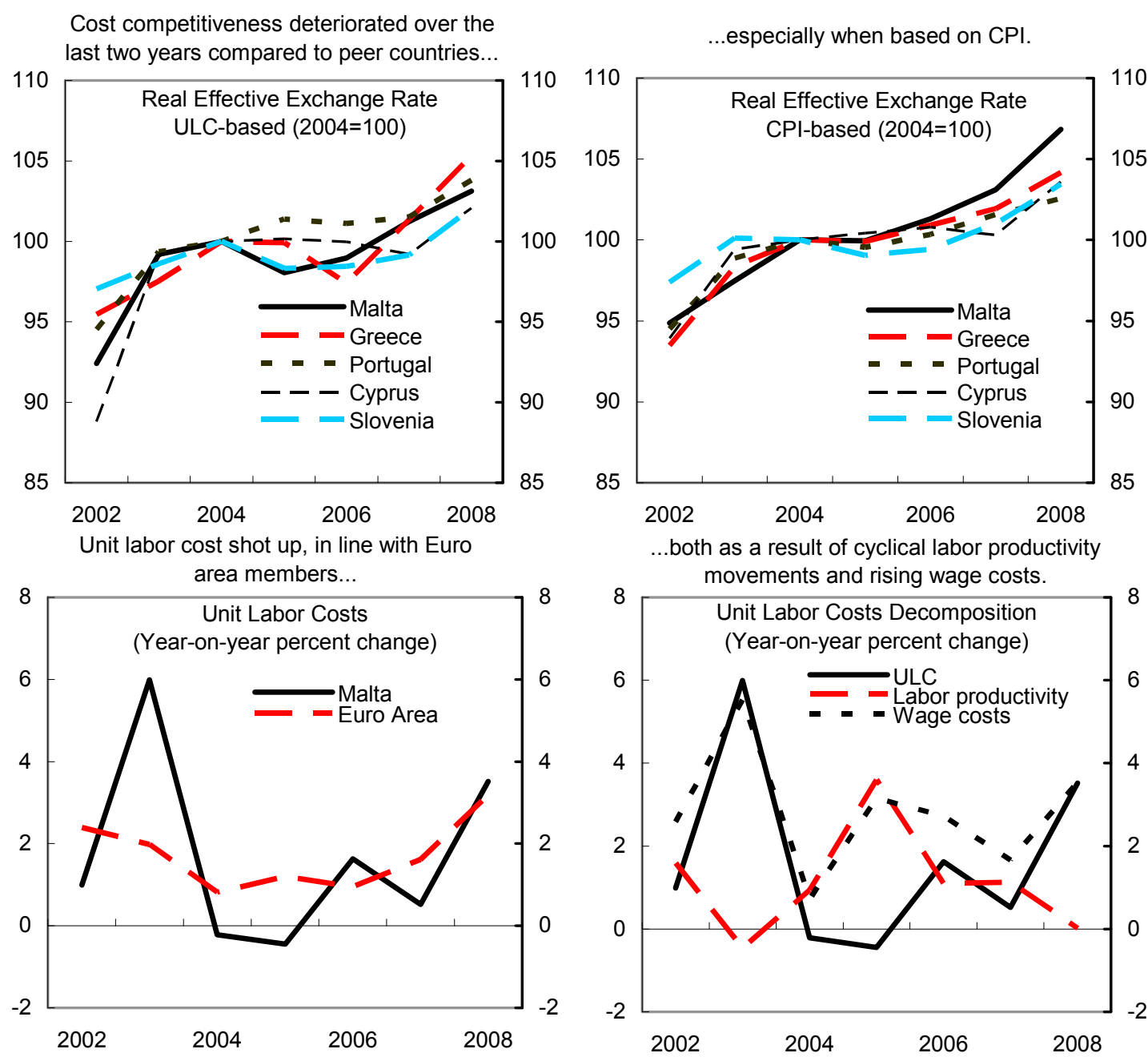

However, the bulk of the loss in competitiveness is linked to the strength of the Euro...

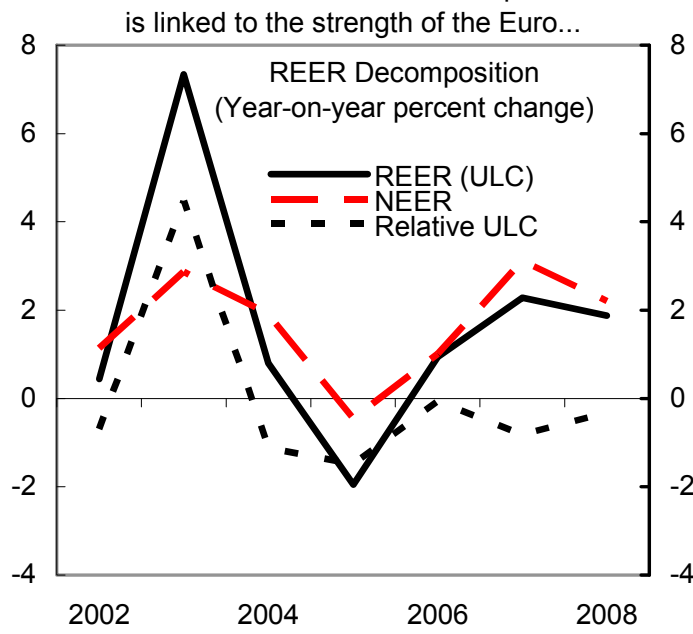

...as Malta is particularly exposed to trade with

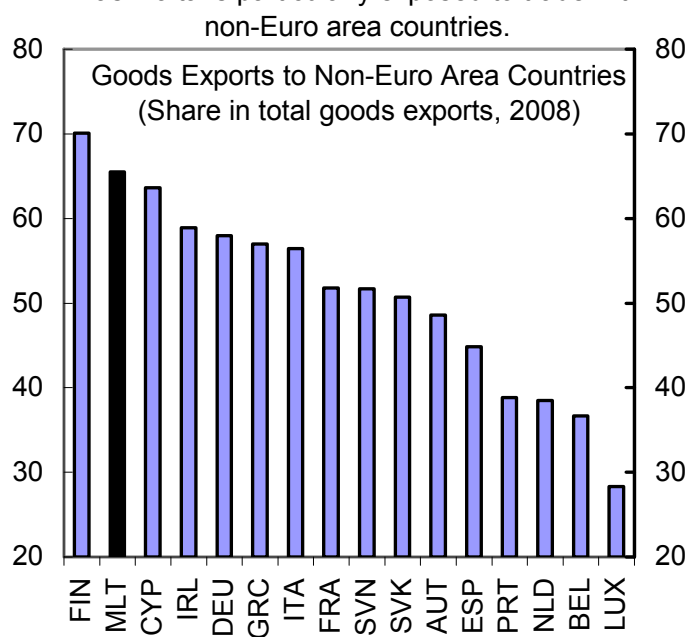

Sources: ECB; European Commission; IFS; and IMF staff calculations. 
the current downturn is testing this strategy, price developments in 2008 also affected cost competitiveness: with wage costs accelerating, labor productivity gains vanishing, and the euro strengthening, Malta's ULC-based real effective exchange rate (REER) appreciated by close to 3 percent against its main trade partners, after an increase of 21/4 percent in 2007. On the other hand, the current account position improved, with the impact of the oil price hike and further cutbacks in the manufacturing sector more than offset by expanding niche exports. Overall, using CGER methodologies, ${ }^{5}$ staff estimates that the competitiveness gap remained broadly similar to last year's, with a modest overvaluation in the range of 2 to 16 percent. These developments support the authorities' view that changes in export structure have underpinned an equilibrium appreciation.

\section{Still, in the current taxing environment, the authorities' strategy to continue} upgrading the exports structure will not succeed without a multipronged approach to promote structural reforms (Figure 10). The authorities underscored that euro area membership has served them well in the current turmoil by avoiding unnecessary currency volatility. Nonetheless, going forward, Malta will not be able to withstand continuous REER appreciation unscathed; allowing for costs adjustments will be critical to remain competitive as a small catching-up member of the currency union, especially given Malta's

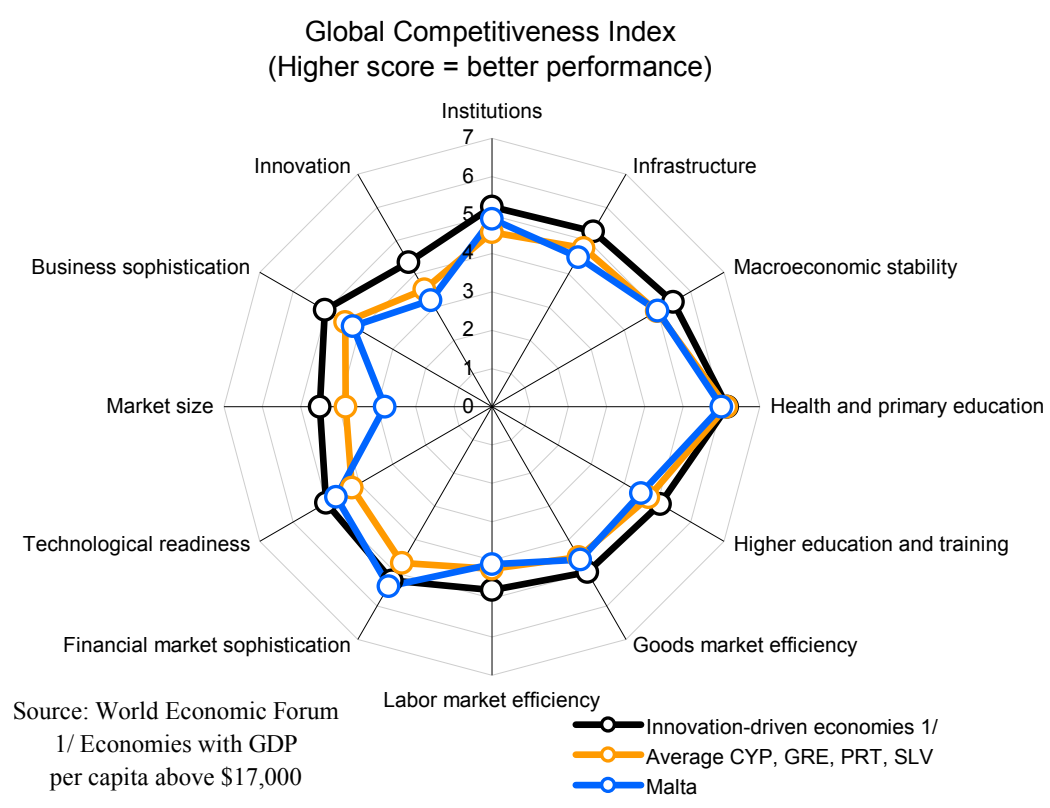
large share of trade with non euro area partners. Due to the small size of the economy, innovation will remain predominantly embedded in FDI; this will require a congenial business climate supported by upgraded infrastructure, a more skilled and flexible labor force, and reduced involvement of the public sector.

\footnotetext{
${ }^{5}$ See "Exchange Rate Assessments: CGER Methodologies" (2008) by Lee, Milesi-Ferretti, Ostry, Prati, and Ricci, IMF Occasional Paper 261.
} 
Figure 10. Malta: Non Price Competitiveness Indicators, 2002-2010

Malta has relied on FDI to built its innovation-driven sectors...

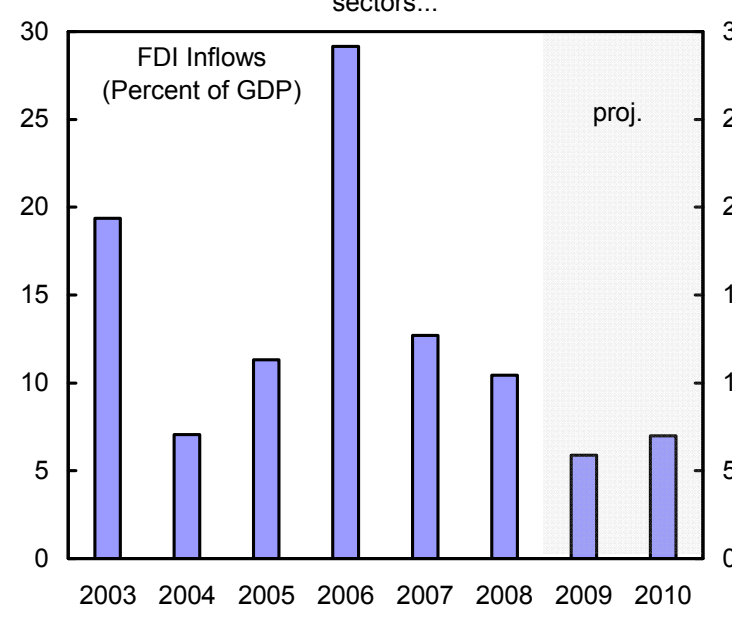

...as domestic R\&D lags behind its peers
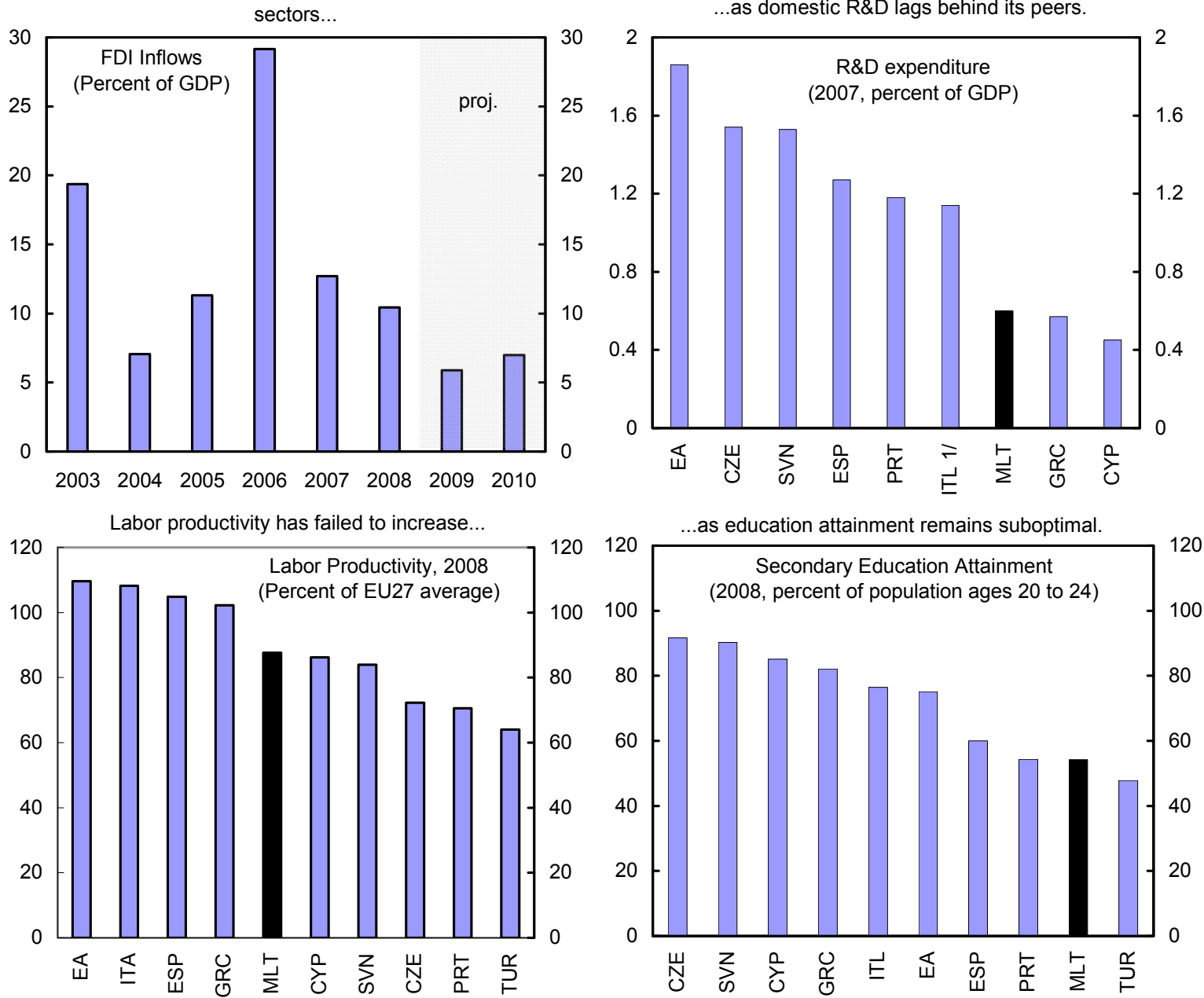

Record-low female labor participation also hampers growth.

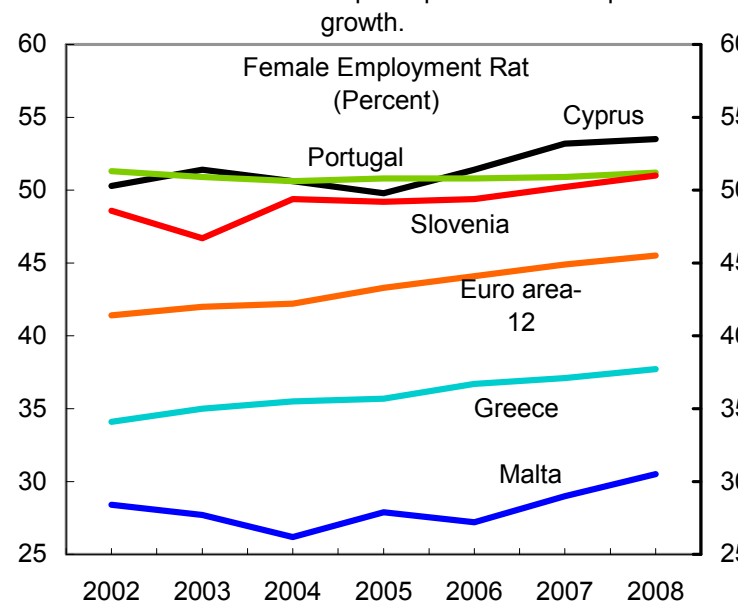

Competitiveness in tourism slightly deteriorated in 2008.

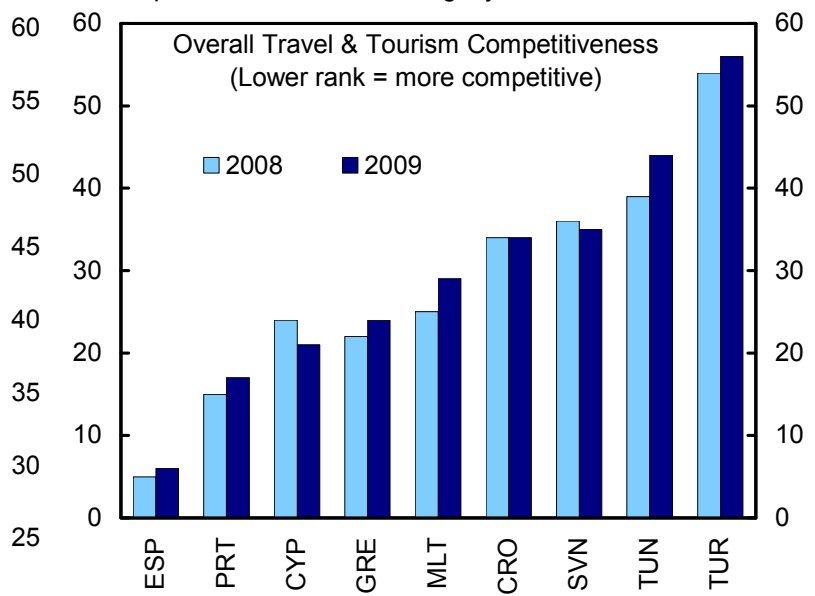

Sources: Eurostat; World Economic Forum, 2009: Travel \& Tourism Competitiveness Report; and IMF staff calculations. 1/ Data for 2006. 


\section{The authorities are committed to reducing the state's involvement in the}

economy. They are finalizing the privatization of the shipyards' activities, and unbundling of Enemalta's gas and petroleum divisions is underway. The authorities have introduced a rule-based mechanism to determine electricity and water tariffs with a view to gradually achieve full cost recovery for the state-owned utility enterprises while providing consumers with transparency and predictability in tariff adjustments. Staff welcomed this important step but warned that the financial situation of Enemalta remained fragile, raising risks the government might still need to support the company financially in the future. The privatization process should continue, including with the search for strategic investors for Bank of Valletta, market conditions permitting.

\section{There was broad agreement that the causes of persistent inflation had to be} rapidly tackled. While the lagged pass-through of oil prices to domestic energy prices accounts for part of the differential in inflation with the euro area, food price inflation has remained high. Staff recommended that the competition authority adopt a more proactive stance, expeditiously addressing any monopolistic behavior in the wholesale and retail markets, while regulated segments of the markets be liberalized. Adequate capacities and institutional independence should be granted to the competition authority.

\section{Wage developments and labor and education policies will also need to play their} role in strengthening Malta's competitive position. Staff stressed that, as inflation remains high, the COLA risked hampering necessary cost adjustments, especially in manufacturing industries hit by the global downturn and in low-skilled employment intensive sectors; staff advised its elimination and instead encouraged a move towards productivity-linked wage increases at the enterprise level. The authorities underscored that the indexation setting had served the country well; they expressed cautious support to staff's suggestion of a social pact to forge consensus on required policies. Upcoming negotiations on the public sector collective agreement should also set a conservative benchmark for the private sector. Malta does not compare well with peers on female employment participation and on education attainment, and incentives to pursue tertiary education and to enter the labor force need to be reinforced. Beyond the recent income tax reform, staff stressed that further efforts were required to address skill mismatches and to clamp down on informal activity.

\section{An infrastructure upgrade would further increase Malta's attraction as an FDI}

destination. The public investment package included in the 2009 budget constitutes an important step to improve Malta's attractiveness. The launch of the first tranche of the Smart City Project, a privately-financed information technology business park, could bear strong potential in attracting further investment in ICT.

\section{Both production and provision of economic statistics have improved. The}

National Statistics Office has now filled senior management vacancies and taken decisive steps to improve the production and timely dissemination of economic indicators. Significant 
progress has been made towards SDDS subscription, which, in consultation with STA, is targeted for end-November 2009.

\section{Staff Appraisal}

34. Following strong structural reforms on the run-up to euro adoption, the Maltese economy is better equipped to handle the global crisis. Activity has been diversified towards high-value added services sectors, which so far have remained relatively less affected by the slowdown. Fiscal consolidation and privatization helped put public finances on a stronger footing for euro adoption in early 2008. Accordingly, the economy remained resilient until the fall of 2008 .

\section{Staff nevertheless projects the economy to shrink by 2 percent in 2009 . Growth} remains influenced by the outlook in the manufacturing and tourism sectors, highly affected by the global crisis. Private consumption and employment prospects have also weakened recently. The downturn will put pressure on government revenue and bank asset quality, and vulnerabilities related to Malta's significant exposure to external developments-both through trade ties and through the large internationally oriented banking sector - call for strong fiscal and financial policies. Staff views the balance of risks still on the downside.

36. Fiscal policy is appropriately accommodating in 2009, and the authorities should be mindful not to withdraw fiscal support too rapidly in 2010 . The stimulus package combined with the full play of automatic stabilizers will provide an appropriate counter-cyclical response to the slowdown, while the reform of utility subsidies will help generate fiscal room and address inefficiencies. However, the composition of the stimulus measures should be improved, with a gradual winding down of measures to support enterprises as the implementation of infrastructure projects gather pace. If risks were to materialize and the recovery be further delayed, the full play of automatic stabilizers - and possibly further capital spending — should be allowed to provide additional support in 2010 .

\section{Without policy adjustment, the fiscal deficit will nonetheless fail to moderate} substantially in the medium term. It would remain in excess of the Maastricht ceiling until 2013, with much of the debt adjustment achieved during 2004-07 erased. The looming challenge of ageing only compounds these fiscal risks.

\section{Anchoring the short-term fiscal response to the downturn within a} well-articulated consolidation strategy will therefore be key. The authorities started tackling the shipyards and the utility subsidies, two areas of traditionally large public outlays. But, more needs to be done to secure sustainability, in particular with respect to the wage bill, subsidies and health care spending. A fiscal strategy aimed at delivering 2/3 percentage point of GDP of structural adjustment annually over 2011-14 would provide a quicker reversal in public debt trend, necessary to re-build fiscal buffers. 
39. A stronger fiscal institutional framework would also help foster consolidation. More independent fiscal projections, stronger budget execution discipline, greater accountability of the government to parliament, and better integration of the medium-term strategy in budgetary discussions would all contribute to anchoring the authorities' consolidation plans.

40. Maltese banks have withstood the global crisis relatively well but vulnerabilities have increased. Credit concentration remains a concern, especially as the downward correction in property markets and the economic slowdown will typically trigger a deterioration in asset quality.

41. More capital buffers are needed. Banks already started tapping the market, and should continue doing so, private appetite permitting, preferably with a focus on core capital. The government has appropriately communicated it stood ready to support banks; legislative work on bank resolution regime and deposit insurance coverage should speedily be finalized. Provisioning should also be more proactive.

42. More broadly, the authorities should assess whether the cost-benefit analysis of Malta's banking business model has been altered by the risks brought to light by the global financial crisis. This applies in particular to the internationally oriented financial sector, whose assets account for more than five times GDP and whose linkages with the domestic economy, though limited, are rising. Containing these risks will require further enhancing supervisory capacities and better incorporating systemic considerations into prudential standards. Closer monitoring of financial sector issues in the ministry of finance will be paramount, given the potentially sizeable impact on public finances in case of crisis.

\section{Completing the structural reform agenda will be critical to buttress}

competitiveness. Euro area membership offers clear opportunities in terms of trade and financial integration, FDI inflows, and exchange rate stability. However, further internal flexibility will be essential for strong performance within the currency union, and a concerted effort from all stakeholders will be required to preserve cost competitiveness and generate productivity gains necessary to raise living standards. A social pact negotiated between the government and the social partners could offer a useful vehicle to forge consensus on policies, including on measures to tackle persistent inflation and to link wage increases to productivity developments at the firm level. The critical reform of the utility tariffs should be completed, and the price-setting formula applied in full and transparently. Finally, the government should continue to place special focus on raising labor market participation and increasing education attainment to fill skill mismatches.

44. It is recommended that Malta remain on a 12-month consultation cycle. 
Table 1. Malta: Selected Economic Indicators, 2005-2014

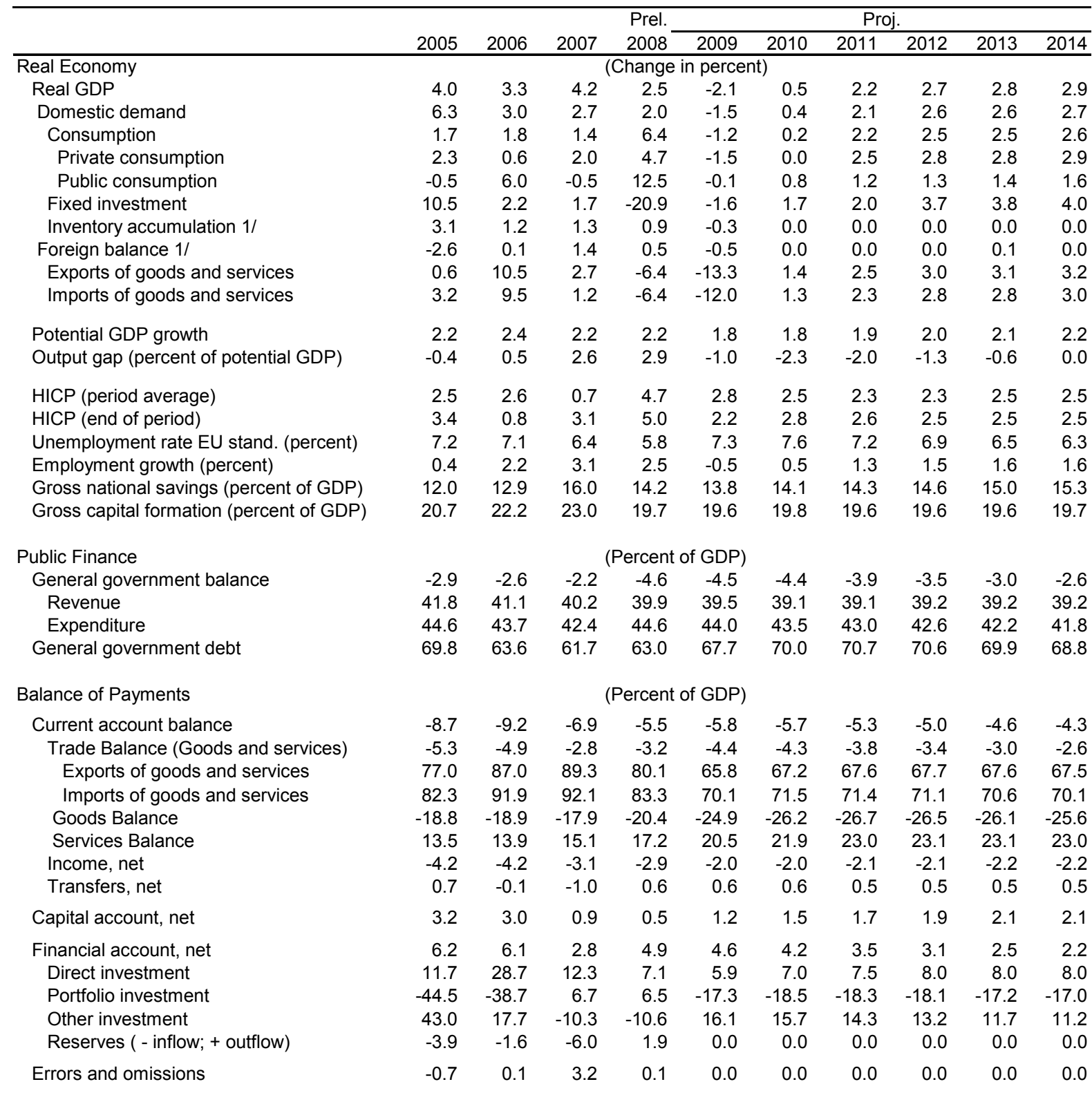

Memorandum Items:

Nominal GDP (Euro Millions)

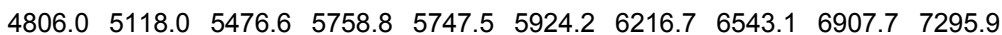

Sources: National Statistics Office; Central Bank of Malta; Eurostat; and IMF staff estimates.

$1 /$ Contribution to growth.

(CInternational Monetary Fund. Not for Redistribution 
Table 2. Malta: Fiscal Developments and Projections, 2004-2014

(Percent of GDP)

\begin{tabular}{|c|c|c|c|c|c|c|c|c|c|c|c|}
\hline & \multirow[b]{2}{*}{2004} & \multirow[b]{2}{*}{2005} & \multirow[b]{2}{*}{2006} & \multirow[b]{2}{*}{2007} & \multirow{2}{*}{$\begin{array}{l}\text { Prel. } \\
2008\end{array}$} & \multicolumn{5}{|c|}{ Proj. } & \multirow[b]{2}{*}{2014} \\
\hline & & & & & & 2009 & 2010 & 2011 & 2012 & 2013 & \\
\hline Revenue & 40.7 & 41.8 & 41.1 & 40.2 & 39.9 & 39.5 & 39.1 & 39.1 & 39.2 & 39.2 & 39.2 \\
\hline Current revenue & 39.0 & 38.5 & 38.1 & 39.1 & 39.5 & 38.5 & 38.3 & 38.4 & 38.5 & 38.5 & 38.5 \\
\hline Tax revenue & 26.0 & 26.9 & 27.0 & 28.2 & 27.6 & 27.2 & 27.1 & 27.1 & 27.2 & 27.2 & 27.2 \\
\hline Indirect taxes & 14.6 & 14.9 & 14.8 & 14.6 & 14.5 & 14.1 & 14.1 & 14.1 & 14.1 & 14.0 & 13.9 \\
\hline Direct taxes & 11.2 & 11.6 & 11.9 & 13.3 & 12.9 & 12.9 & 12.8 & 12.8 & 12.9 & 13.0 & 13.1 \\
\hline Other taxes (capital taxes) & 0.2 & 0.4 & 0.3 & 0.3 & 0.3 & 0.2 & 0.2 & 0.2 & 0.2 & 0.2 & 0.2 \\
\hline Social security contributions & 8.0 & 7.9 & 7.6 & 7.3 & 7.5 & 7.6 & 7.6 & 7.7 & 7.7 & 7.7 & 7.7 \\
\hline Other current revenue & 5.0 & 3.7 & 3.5 & 3.7 & 4.3 & 3.7 & 3.6 & 3.6 & 3.6 & 3.6 & 3.6 \\
\hline Capital revenue & 1.8 & 3.2 & 3.0 & 1.0 & 0.4 & 0.9 & 0.8 & 0.6 & 0.6 & 0.6 & 0.6 \\
\hline Expenditure & 45.5 & 44.6 & 43.7 & 42.4 & 44.6 & 44.0 & 43.5 & 43.0 & 42.6 & 42.2 & 41.8 \\
\hline Current expenditure & 40.9 & 39.7 & 39.2 & 38.5 & 41.2 & 40.2 & 39.8 & 39.5 & 39.1 & 38.6 & 38.3 \\
\hline Wages and salaries & 14.6 & 13.9 & 13.3 & 12.9 & 14.4 & 14.0 & 14.0 & 13.9 & 13.8 & 13.6 & 13.5 \\
\hline Goods and services & 5.5 & 5.0 & 5.7 & 5.3 & 6.7 & 6.2 & 6.2 & 6.0 & 5.9 & 5.8 & 5.8 \\
\hline Social Transfers & 13.3 & 13.4 & 13.0 & 13.1 & 13.2 & 13.6 & 13.3 & 13.2 & 13.1 & 13.0 & 12.8 \\
\hline Subsidies & 1.9 & 2.1 & 2.1 & 2.1 & 2.2 & 1.3 & 1.1 & 1.1 & 1.1 & 1.1 & 1.1 \\
\hline Interest payments & 3.6 & 3.7 & 3.5 & 3.3 & 3.3 & 3.4 & 3.6 & 3.7 & 3.7 & 3.7 & 3.6 \\
\hline Other current expenditure & 1.9 & 1.7 & 1.5 & 1.7 & 1.6 & 1.6 & 1.6 & 1.6 & 1.6 & 1.6 & 1.6 \\
\hline Capital expenditure & 4.5 & 4.9 & 4.5 & 3.9 & 3.3 & 3.8 & 3.7 & 3.5 & 3.5 & 3.5 & 3.5 \\
\hline Overall balance & -4.7 & -2.9 & -2.6 & -2.2 & -4.6 & -4.5 & -4.4 & -3.9 & -3.5 & -3.0 & -2.6 \\
\hline Overall balance excl. one-offs & -5.5 & -4.4 & -3.2 & -2.8 & -3.8 & -4.4 & -4.5 & -4.0 & -3.5 & -3.0 & -2.6 \\
\hline \multicolumn{12}{|l|}{ Memorandum items } \\
\hline Cyclically adjusted overall balance & -3.9 & -2.7 & -2.7 & -3.1 & -5.7 & -4.2 & -3.6 & -3.2 & -3.0 & -2.8 & -2.6 \\
\hline Cyclically adjusted overall balance, excl. one-offs & -4.7 & -4.3 & -3.4 & -3.8 & -4.9 & -4.1 & -3.7 & -3.3 & -3.0 & -2.8 & -2.6 \\
\hline Primary balance & -1.1 & 0.8 & 1.0 & 1.1 & -1.4 & -1.1 & -0.8 & -0.3 & 0.2 & 0.7 & 0.9 \\
\hline One-offs & 0.8 & 1.5 & 0.7 & 0.6 & -0.9 & -0.1 & 0.1 & 0.1 & 0.0 & 0.0 & 0.0 \\
\hline o/w: Malta Shipyards reclassification/liquidation & & & & & -1.1 & -0.4 & & & & & \\
\hline Public debt & 72.1 & 69.8 & 63.6 & 61.7 & 63.0 & 67.7 & 70.0 & 70.7 & 70.6 & 69.9 & 68.8 \\
\hline Government guaranteed debt & 13.5 & 13.1 & 11.3 & 11.5 & 12.2 & & & & & & \\
\hline
\end{tabular}

Sources: National Statistics Office, Eurostat, and IMF staff estimates. 
Table 3. Malta: Balance of Payments, 2005-2014

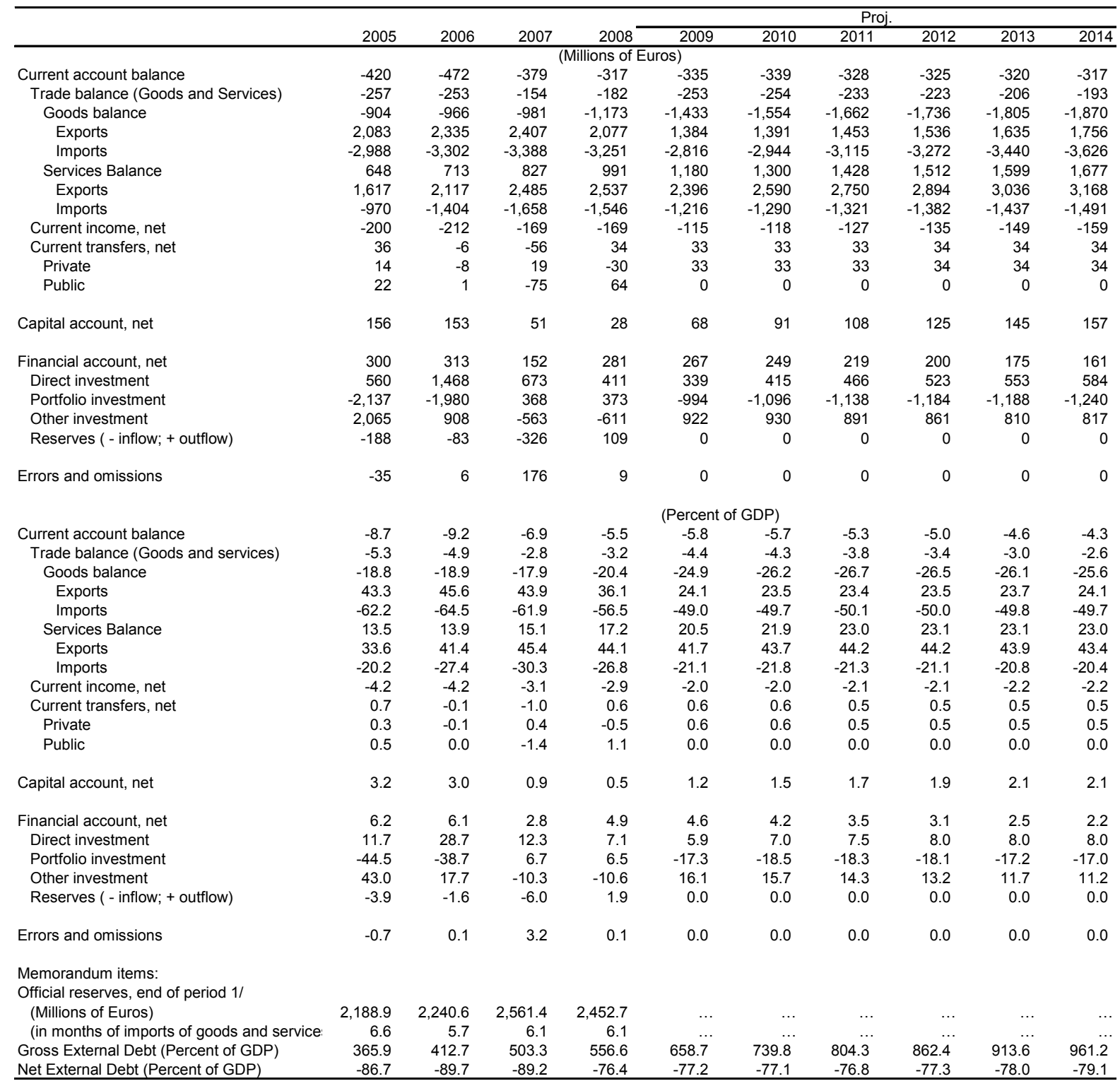

Sources: National Statistics Office; and IMF staff estimates.

1/ Projection for 2008. 
Table 4. Malta: International Investment Position, 2002-2008

\begin{tabular}{|c|c|c|c|c|c|c|c|}
\hline & 2002 & 2003 & 2004 & 2005 & 2006 & 2007 & $\begin{array}{l}\text { Proj. } \\
2008\end{array}$ \\
\hline & \multicolumn{7}{|c|}{ (Millions of Euros) } \\
\hline International Investment Position & 1,502 & 1,784 & 1,815 & 1,779 & 1,419 & 1,157 & 877 \\
\hline Direct Investment & $-1,989$ & $-1,881$ & $-2,159$ & $-2,805$ & $-4,121$ & $-4,782$ & $-5,192$ \\
\hline Assets & 253 & 737 & 823 & 841 & 873 & 830 & 1,020 \\
\hline Liabilities & $-2,242$ & $-2,618$ & $-2,982$ & $-3,645$ & $-4,994$ & $-5,612$ & $-6,212$ \\
\hline Portfolio Investment & 3,700 & 5,271 & 6,790 & 9,641 & 10,963 & 10,289 & 9,916 \\
\hline Assets & 4,043 & 5,601 & 7,144 & 10,054 & 11,371 & 10,696 & 10,495 \\
\hline Liabilities & -343 & -329 & -355 & -413 & -408 & -407 & -579 \\
\hline o/w: Debt instruments & -294 & -292 & -237 & -231 & -222 & -228 & -387 \\
\hline Financial Derivatives & 0 & -21 & -27 & -2 & -15 & 28 & 371 \\
\hline Other Investment & $-2,261$ & $-3,786$ & $-4,818$ & $-7,244$ & $-7,649$ & $-6,939$ & $-6,671$ \\
\hline Assets & 5,624 & 5,803 & 6,745 & 9,596 & 12,351 & 19,393 & 23,797 \\
\hline Liabilities & $-7,885$ & $-9,590$ & $-11,563$ & $-16,839$ & $-19,999$ & $-26,332$ & $-30,467$ \\
\hline \multirow[t]{2}{*}{ Reserves } & 2,052 & 2,200 & 2,029 & 2,189 & 2,241 & 2,561 & 2,453 \\
\hline & \multicolumn{7}{|c|}{ (Percent of GDP) } \\
\hline International Investment Position & 35.1 & 40.6 & 40.3 & 37.0 & 27.7 & 21.1 & 15.2 \\
\hline Direct Investment & -46.5 & -42.9 & -47.9 & -58.4 & -80.5 & -87.3 & -90.2 \\
\hline Assets & 5.9 & 16.8 & 18.3 & 17.5 & 17.1 & 15.2 & 17.7 \\
\hline Liabilities & -52.4 & -59.6 & -66.2 & -75.9 & -97.6 & -102.5 & -107.9 \\
\hline Portfolio Investment & 86.5 & 120.1 & 150.8 & 200.6 & 214.2 & 187.9 & 172.2 \\
\hline Assets & 94.6 & 127.6 & 158.6 & 209.2 & 222.2 & 195.3 & 182.2 \\
\hline $\begin{array}{l}\text { Liabilities } \\
\text { o/w: Debt instruments }\end{array}$ & -8.0 & -7.5 & -7.9 & -8.6 & -8.0 & -7.4 & -10.0 \\
\hline Financial Derivatives & 0.0 & -0.5 & -0.6 & 0.0 & -0.3 & 0.5 & 6.4 \\
\hline Other Investment & -52.9 & -86.3 & -107.0 & -150.7 & -149.4 & -126.7 & -115.8 \\
\hline Assets & 131.5 & 132.2 & 149.8 & 199.7 & 241.3 & 354.1 & 413.2 \\
\hline Liabilities & -184.4 & -218.5 & -256.7 & -350.4 & -390.8 & -480.8 & -529.1 \\
\hline Reserves & 48.0 & 50.1 & 45.1 & 45.5 & 43.8 & 46.8 & 42.6 \\
\hline \multicolumn{8}{|l|}{ Memorandum Item: } \\
\hline Gross External Debt (Euro Millions) & $8,899.2$ & $10,157.0$ & $12,120.4$ & $17,585.1$ & $21,123.8$ & $27,562.7$ & $32,053.5$ \\
\hline Gross External Debt (Percent of GDP) & 208.1 & 231.5 & 269.1 & 365.9 & 412.7 & 503.3 & 556.6 \\
\hline Net External Debt (Percent of GDP) & -27.5 & -81.9 & -86.8 & -86.7 & -89.7 & -89.2 & -76.4 \\
\hline
\end{tabular}

Sources: Central Bank of Malta; and IMF staff estimates. 
Table 5. Malta: External Debt Sustainability Framework, 2004-2014 (In percent of GDP, unless otherwise indicated)

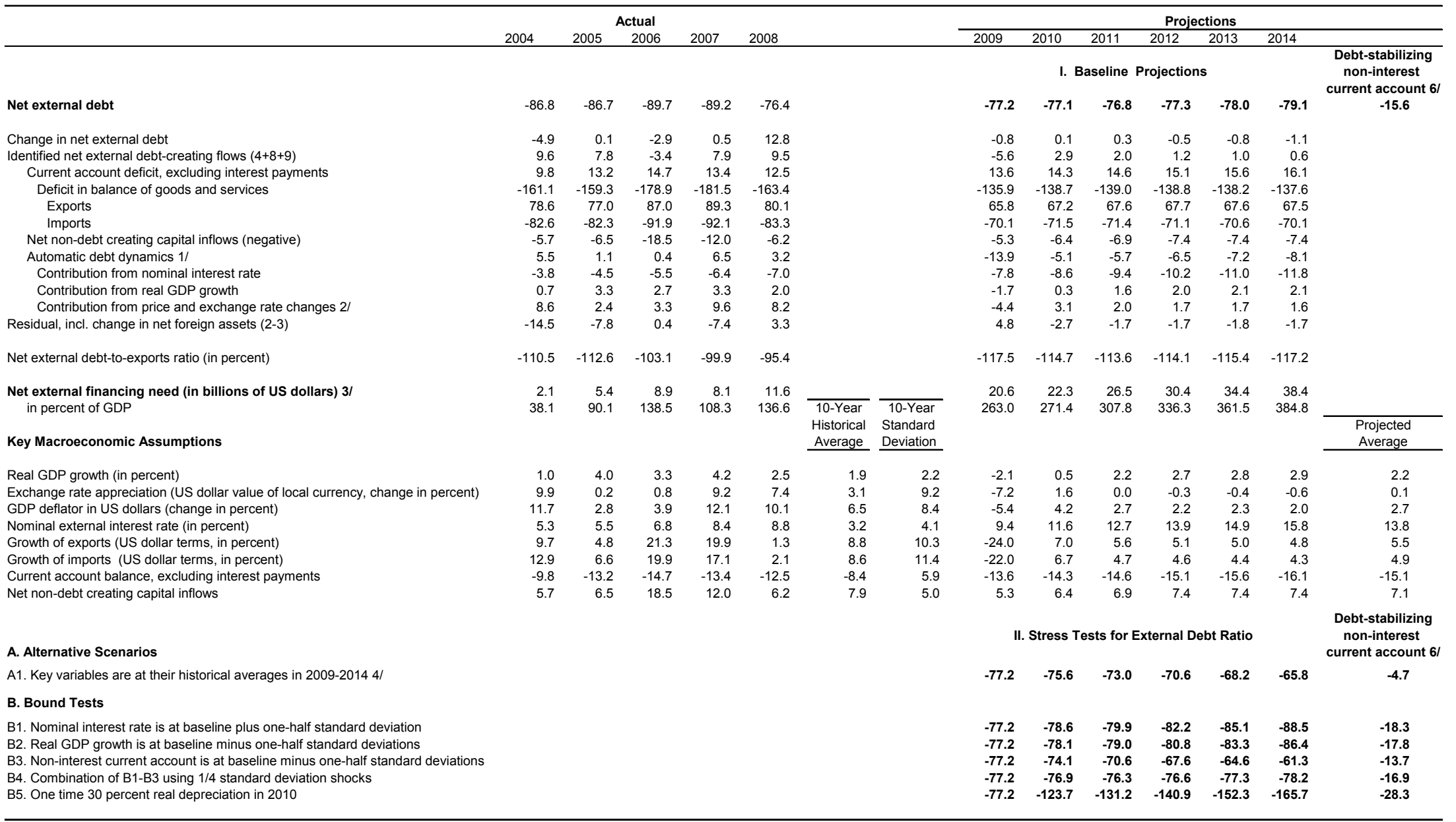

1/ Derived as $[r-g-r(1+g)+$ ea $(1+r)](1+g+r+g r)$ times previous period debt stock, with $r=$ nominal effective interest rate on external debt; $r=$ change in domestic GDP deffator in US dollar terms, $g=$ real GDP growth rate, $\mathrm{e}=$ nominal appreciation (increase in dollar value of domestic currency), and $\mathrm{a}=$ share of domestic-currency denominated debt in total external debt.

$2 /$ The contribution from price and exchange rate changes is defined as $[-r(1+g)+e a(1+r)](1+g+r+g r)$ times previous period debt stock. r increases with an appreciating domestic currency $(e>0)$ and rising inflation (based on GDP deflator).

amortization on medium- and long-term debt, plus short-term debt at end of previous period.

4/ The key variables include real GDP growth; nominal interest rate; dollar deflator growth; and both non-interest current account and non-debt inflows in percent of GDP.

(real GDP growth, nominal interest rate, dollar deflator growth, and non-debt inflows in percent of GDP) remain

at their levels of the last projection year. 
Table 6. Malta: Public Sector Debt Sustainability Framework, 2004-2014

(In percent of GDP, unless otherwise indicated)

\begin{tabular}{|c|c|c|c|c|c|c|c|c|c|c|c|c|c|c|}
\hline \multirow[b]{4}{*}{$\begin{array}{l}\text { Public sector debt } 1 / \\
\text { o/w foreign-currency denominated }\end{array}$} & \multirow{4}{*}{$\begin{array}{r}2004 \\
\\
72.1 \\
0.3\end{array}$} & \multicolumn{4}{|c|}{ Actual } & \multicolumn{9}{|c|}{ Projections } \\
\hline & & 2005 & 2006 & 2007 & 2008 & & & 2009 & 2010 & 2011 & 2012 & 2013 & 2014 & \multirow{3}{*}{$\begin{array}{c}\text { Debt-stabilizing } \\
\text { primary } \\
\text { balance 10/ } \\
-0.1\end{array}$} \\
\hline & & & & & & & & \multicolumn{6}{|c|}{ I. Baseline Projections } & \\
\hline & & $\begin{array}{r}69.8 \\
0.3\end{array}$ & $\begin{array}{r}63.6 \\
0.2\end{array}$ & $\begin{array}{r}61.7 \\
0.1\end{array}$ & $\begin{array}{r}63.0 \\
0.0\end{array}$ & & & $\begin{array}{r}67.7 \\
0.0\end{array}$ & $\begin{array}{r}70.0 \\
0.0\end{array}$ & $\begin{array}{r}70.7 \\
0.0\end{array}$ & $\begin{array}{rl}70.6 & 0 \\
0.0 & 0\end{array}$ & $\begin{array}{r}69.9 \\
0.0\end{array}$ & $\begin{array}{r}68.8 \\
0.0\end{array}$ & \\
\hline Change in public sector debt & 2.9 & -2.3 & -6.2 & -1.9 & 1.3 & & & 4.7 & 2.4 & 0.6 & 0.0 & -0.7 & -1.1 & \\
\hline Identified debt-creating flows $(4+7+12)$ & 2.9 & -2.9 & -5.1 & -2.5 & 1.6 & & & 4.7 & 2.4 & 0.6 & 0.0 & -0.7 & -1.1 & \\
\hline Primary deficit & 1.1 & -0.8 & -1.0 & -1.1 & 1.4 & & & 1.1 & 0.8 & 0.3 & -0.2 & -0.7 & -0.9 & \\
\hline Revenue and grants & 40.7 & 41.8 & 41.1 & 40.2 & 39.9 & & & 39.5 & 39.1 & 39.1 & 39.2 & 39.2 & 39.2 & \\
\hline Primary (noninterest) expenditure & 41.8 & 40.9 & 40.2 & 39.1 & 41.3 & & & 40.5 & 39.9 & 39.3 & 39.0 & 38.5 & 38.3 & \\
\hline Automatic debt dynamics 21 & 1.8 & -0.8 & -0.7 & -0.9 & 0.2 & & & 3.6 & 1.6 & 0.4 & 0.1 & -0.1 & -0.2 & \\
\hline Contribution from interest rate/growth differential 3/ & 1.9 & -0.8 & -0.7 & -0.8 & 0.2 & & & 3.6 & 1.6 & 0.4 & 0.1 & -0.1 & -0.2 & \\
\hline Of which contribution from real interest rate & 2.5 & 1.9 & 1.4 & 1.7 & 1.7 & & & 2.3 & 1.9 & 1.9 & 2.0 & 1.8 & 1.7 & \\
\hline Of which contribution from real GDP growth & -0.7 & -2.7 & -2.2 & -2.5 & -1.5 & & & 1.3 & -0.3 & -1.5 & -1.8 & -1.9 & -1.9 & \\
\hline Contribution from exchange rate depreciation $4 /$ & 0.0 & 0.0 & 0.0 & 0.0 & 0.0 & & & 0.0 & 0.0 & 0.0 & 0.0 & 0.0 & 0.0 & \\
\hline Other identified debt-creating flows & 0.0 & -1.2 & -3.4 & -0.5 & 0.0 & & & 0.0 & 0.0 & 0.0 & 0.0 & 0.0 & 0.0 & \\
\hline Privatization receipts (negative) & 0.0 & -1.2 & -3.4 & -0.5 & 0.0 & & & 0.0 & 0.0 & 0.0 & 0.0 & 0.0 & 0.0 & \\
\hline Recognition of implicit or contingent liabilities & 0.0 & 0.0 & 0.0 & 0.0 & 0.0 & & & 0.0 & 0.0 & 0.0 & 0.0 & 0.0 & 0.0 & \\
\hline $\begin{array}{l}\text { Other (specify, e.g. bank recapitalization) } \\
\text { Residualusting asset }\end{array}$ & 0.0 & 0.0 & 0.0 & 0.0 & $\begin{array}{r}0.0 \\
-0.3\end{array}$ & & & 0.0 & 0.0 & 0.0 & 0.0 & 0.0 & 0.0 & \\
\hline Public sector debt-to-revenue ratio $1 /$ & 1771 & 1671 & 1546 & 1535 & 1578 & & & 1715 & 1790 & 1810 & 1804 & 1786 & 1757 & \\
\hline & & & & & & & & & & & & & & \\
\hline $\begin{array}{l}\text { Gross financing need } 5 / \\
\text { in billions of } U S \text { dollars }\end{array}$ & $\begin{array}{c}16.7 \\
0.9\end{array}$ & $\begin{array}{c}14.5 \\
0.9\end{array}$ & $\begin{array}{r}13.1 \\
0.8\end{array}$ & $\begin{array}{r}12.5 \\
0.9\end{array}$ & $\begin{array}{c}15.1 \\
1.3\end{array}$ & 10-Year & $10-Y e a r$ & $\begin{array}{r}15.8 \\
12\end{array}$ & 16.1 & $\begin{array}{r}15.7 \\
1.4\end{array}$ & $\begin{array}{r}15.3 \\
1.4\end{array}$ & $\begin{array}{r}14.7 \\
1.4\end{array}$ & $\begin{array}{c}14.1 \\
1.4\end{array}$ & \\
\hline Key Macroeconomic and Fiscal Assumptions & & & & & & $\begin{array}{l}\text { Therear } \\
\text { Historical } \\
\text { Average } \\
\end{array}$ & $\begin{array}{l}\text { Th-rear } \\
\text { Standard } \\
\text { Deviation } \\
\end{array}$ & & & & & & & $\begin{array}{l}\text { Projected } \\
\text { Average }\end{array}$ \\
\hline Real GDP growth (in percent) & 1.0 & 4.0 & 3.3 & 4.2 & 2.5 & 1.9 & 2.2 & -2.1 & 0.5 & 2.2 & 2.7 & 2.8 & 2.9 & 2.2 \\
\hline Average nominal interest rate on public $d$ & $\begin{array}{l}1.0 \\
5.4\end{array}$ & $\begin{array}{l}4.0 \\
5.5\end{array}$ & 5.4 & $\begin{array}{l}4.2 \\
5.6\end{array}$ & 5.6 & 6.0 & 0.7 & 5.5 & 5.5 & 5.5 & 5.5 & $\begin{array}{l}2.8 \\
5.5\end{array}$ & 5.4 & 5.5 \\
\hline Average real interest rate (nominal rate minus change in GDP deflator, in percent) & 3.8 & 2.9 & 2.3 & 2.9 & 3.0 & 2.6 & 2.4 & 3.5 & 2.9 & 2.8 & 3.0 & 2.8 & 2.7 & 2.8 \\
\hline Nominal appreciation (increase in US dollar value of local currency, in percent) & $\begin{array}{l}9.0 \\
9.9\end{array}$ & 0.2 & 0.8 & 9.2 & 7.4 & 3.1 & 9.2 & $\begin{array}{r}3.5 \\
-7.2\end{array}$ & 1.6 & 0.0 & -0.3 & -0.4 & -0.6 & 0.1 \\
\hline Inflation rate (GDP deflator, in percent) & 1.6 & 2.6 & 3.1 & 2.7 & 2.5 & $\begin{array}{l}3.1 \\
3.4\end{array}$ & 2.6 & 1.9 & $\begin{array}{l}2.6 \\
2.6\end{array}$ & 2.7 & 2.5 & $\begin{array}{l}-0.4 \\
2.7\end{array}$ & 2.7 & 2.6 \\
\hline Growth of real primary spending (deflated by GDP deflator, in percent) & -4.8 & 1.9 & 1.3 & 1.3 & 8.4 & 2.3 & 5.3 & -3.9 & -1.1 & 0.7 & 1.8 & 1.5 & 2.3 & 1.0 \\
\hline Primary deficit & 1.1 & -0.8 & -1.0 & -1.1 & 1.4 & 1.7 & 2.4 & 1.1 & 0.8 & 0.3 & -0.2 & -0.7 & -0.9 & -0.1 \\
\hline A. Alternative Scenarios & & & & & & & & \multicolumn{6}{|c|}{ II. Stress Tests for Public Debt Ratio } & $\begin{array}{c}\text { Debt-stabilizing } \\
\text { primary } \\
\text { balance 10/ }\end{array}$ \\
\hline A1. Key variables are at their historical averages in 2009-2014 7/ & & & & & & & & 67.7 & 69.8 & 72.0 & 74.2 & 76.5 & 78.7 & 0.5 \\
\hline A2. No policy change (constant primary balance) in 2009-201 & & & & & & & & 67.7 & 70.3 & 71.8 & 73.0 & 74.1 & 75.0 & -0.2 \\
\hline \multicolumn{15}{|l|}{ B. Bound Tests } \\
\hline B1. Real interest rate is at baseline plus one $s$ & & & & & & & & 67.7 & 70.8 & 72.3 & 73.0 & 73.1 & 72.9 & 0.7 \\
\hline B2. Real C & & & & & & & & 67.7 & 71.2 & 73.5 & 75.5 & 77.3 & 79.2 & 0.7 \\
\hline B3. Primary balance is $\mathrm{s}$ & & & & & & & & 67.7 & 71.2 & 73.1 & 74.3 & 74.7 & 74.9 & -0.2 \\
\hline B4. Combination of B1-B3 using one-quarter standard deviation shocks & & & & & & & & 67.7 & 71.4 & 73.5 & 74.8 & 75.5 & 75.9 & 0.7 \\
\hline B5. One time 30 percent real depreciation in $20109 /$ & & & & & & & & 67.7 & 70.1 & 70.7 & 70.7 & 69.9 & 68.9 & -0.1 \\
\hline B6. 10 percent of GDP increase in other debt-creating flows in 2010 & & & & & & & & 67.7 & 80.0 & 80.7 & 80.7 & 80.0 & 78.9 & -0.2 \\
\hline
\end{tabular}

1/ General government and gross debt.

2/ Derived as $[(r-p(1+g)-g+a e(1+r)](1+g+p+g p))$ times previous period debt ratio, with $r=$ interest rate; $p=$ growth rate of GDP deflator; $g=$ real GDP growth rate; $a=$ share of foreign-currency

denominated debt; and $\mathrm{e}=$ nominal exchange rate depreciation (measured by increase in local currency value of U.S. dollar).

$3 /$ The real interest rate contribution is derived from the denominator in footnote $2 /$ as $r-\pi(1+g)$ and the real growth contribution as $-g$.

6/ Derived as nominal interest expenditure divided by previous period debt stock.

7/ The key variables include real GDP growth; real interest rate; and primary balance in percent of GDP.

$3 /$ The implied change in other key variables under this scenario is discussed in the text.

作

CInternational Monetary Fund. Not for Redistribution 
Table 7. Malta: Financial Soundness Indicators, 2004-2008

(Percent)

\begin{tabular}{|c|c|c|c|c|c|}
\hline & 2004 & 2005 & 2006 & 2007 & 2008 \\
\hline \multicolumn{6}{|l|}{ Banking sector (unless noted, includes internationally-oriented banks) } \\
\hline Regulatory capital to risk-weighted assets & 21.3 & 20.4 & 22.0 & 21.0 & 17.7 \\
\hline Regulatory Tier 1 capital to risk-weighted assets & 18.3 & 19.0 & 20.8 & 19.7 & 15.6 \\
\hline Nonperforming loans net of provisions to capital & 30.0 & 20.1 & 12.5 & 10.6 & 10.8 \\
\hline Nonperforming loans to total gross loans & 6.5 & 3.9 & 2.8 & 1.8 & 1.6 \\
\hline Return on assets & 1.4 & 1.4 & 1.3 & 1.0 & 0.7 \\
\hline Return on equity & 11.9 & 13.0 & 12.7 & 11.9 & 4.5 \\
\hline Interest margin to gross income & 45.4 & 48.6 & 56.4 & 56.3 & 58.6 \\
\hline Noninterest expenses to gross income & 47.2 & 41.4 & 44.4 & 53.8 & 61.6 \\
\hline Liquid assets to total assets & 24.3 & 21.7 & 19.7 & 21.9 & 17.6 \\
\hline Liquid assets to short-term liabilities & 49.9 & 55.7 & 52.5 & 52.6 & 49.5 \\
\hline Net open position in foreign exchange to capital $1 /$ & $\ldots$ & $\ldots$ & $\ldots$ & $\ldots$ & 11.6 \\
\hline Capital to assets & 13.7 & 12.9 & 14.2 & 13.7 & 12.6 \\
\hline Gross asset position in financial derivatives to capital & 0.9 & 1.4 & 1.2 & 1.8 & 5.9 \\
\hline Gross liability position in financial derivatives to capital & 2.7 & 1.9 & 1.4 & 1.1 & 5.1 \\
\hline Trading income to total income $2 /$ & $\ldots$ & $\ldots$ & $\ldots$ & $\ldots$ & 2.7 \\
\hline Personnel expenses to noninterest expenses & 38.9 & 40.9 & 36.8 & 25.7 & 25.4 \\
\hline Customer deposits to total (noninterbank) loans & 100.8 & 100.1 & 75.4 & 66.0 & 58.7 \\
\hline Net open position in equities to capital & 38.2 & 34.5 & 24.9 & 20.7 & 11.6 \\
\hline Residential real estate loans to total loans & 13.7 & 13.2 & 12.8 & 10.5 & 9.5 \\
\hline Commercial real estate loans to total loans & 19.4 & 18.2 & 18.2 & 20.4 & 19.4 \\
\hline \multicolumn{6}{|l|}{ Domestically oriented banks } \\
\hline Regulatory capital to risk-weighted assets & 19.0 & 17.1 & 15.0 & 15.8 & 14.5 \\
\hline Regulatory Tier 1 capital to risk-weighted assets & 15.4 & 15.6 & 13.5 & 13.6 & 12.5 \\
\hline Nonperforming loans net of provisions to capital & 41.6 & 33.6 & 29.9 & 26.3 & 26.8 \\
\hline Nonperforming loans to total gross loans & 10.3 & 7.4 & 6.0 & 5.2 & 4.8 \\
\hline Return on assets & 1.5 & 1.6 & 1.8 & 1.5 & -0.4 \\
\hline Return on equity & 12.3 & 12.8 & 15.5 & 14.1 & -3.8 \\
\hline Interest margin to gross income & 67.2 & 66.0 & 64.6 & 67.5 & 152.8 \\
\hline Noninterest expenses to gross income & 46.3 & 46.0 & 44.1 & 43.6 & 108.8 \\
\hline Liquid assets to total assets & 20.9 & 23.1 & 21.8 & 24.3 & 20.3 \\
\hline Liquid assets to short-term liabilities & 46.7 & 53.0 & 50.3 & 49.0 & 45.1 \\
\hline Net open position in foreign exchange to capital $1 /$ & 3.2 & -3.2 & 0.9 & 1.1 & -0.8 \\
\hline Capital to assets & 12.7 & 12.0 & 10.9 & 10.5 & 9.5 \\
\hline Gross asset position in financial derivatives to capital & 1.2 & 2.4 & 3.0 & 3.5 & 15.1 \\
\hline Gross liability position in financial derivatives to capital & 3.7 & 3.0 & 3.3 & 2.4 & 8.3 \\
\hline Trading income to total income $2 /$ & $\ldots$ & $\ldots$ & $\ldots$ & $\ldots$ & -107.6 \\
\hline Personnel expenses to noninterest expenses & 59.2 & 54.0 & 53.9 & 55.9 & 55.0 \\
\hline Customer deposits to total (noninterbank) loans & 132.5 & 132.2 & 128.7 & 136.2 & 120.3 \\
\hline Net open position in equities to capital & 44.9 & 47.1 & 48.4 & 41.3 & 21.0 \\
\hline Residential real estate loans to total loans & 22.2 & 25.3 & 27.2 & 31.1 & 30.0 \\
\hline Commercial real estate loans to total loans & 29.8 & 32.3 & 33.1 & 33.4 & 31.8 \\
\hline Spread between reference lending and deposit rates (in basis points) & & 346.7 & 344.8 & 349.3 & 240.9 \\
\hline Residential real estate prices (annual percentage increase) & 16.3 & 9.6 & 1.0 & 0.1 & -4.4 \\
\hline
\end{tabular}

Source: Central Bank of Malta.

$1 /$ Break in time series in 2007 due to change in the reporting schedule.

2/ Prior to 2008 a different methodology was used. The results under the old methodology for 2007 were

10.5 and -5 , and for 2008 the results were -5.7 and -122.4 for the total and domestically oriented banks, respectively. 
Table 8. Malta: Indicators of External and Banking Sector Vulnerability, 2004-2009 (Percent of GDP, unless otherwise indicated)

\begin{tabular}{|c|c|c|c|c|c|c|c|}
\hline & & & & & & \multicolumn{2}{|c|}{$\begin{array}{c}\text { Latest } \\
\text { observatior }\end{array}$} \\
\hline & 2004 & 2005 & 2006 & 2007 & 2008 & 2009 & date \\
\hline \multicolumn{8}{|l|}{ Financial indicators } \\
\hline Government debt & 72.1 & 69.8 & 63.6 & 61.7 & 63.0 & & \\
\hline Broad money (percent change) 1/ 2/ & 3.9 & 1.3 & 4.4 & 11.5 & -4.6 & -0.5 & May \\
\hline Credit to nonbank private sector (percent change) $3 /$ & 6.4 & 5.6 & 10.3 & 12.2 & 12.2 & 13.7 & May \\
\hline Three month T-bill yield (percent) & 2.9 & 3.2 & 3.5 & 4.3 & 4.3 & 2.2 & May \\
\hline Nonperforming loans (all banks; percent of total gross loans) & 6.5 & 3.9 & 2.8 & 1.8 & 1.6 & & \\
\hline \multicolumn{8}{|l|}{ External indicators } \\
\hline Exports of G\&NFS (percent change, average in U.S. dollars) & 10.1 & 4.4 & 21.3 & 19.9 & 1.3 & & \\
\hline Imports of G\&NFS (percent change, average in U.S. dollars) & 13.2 & 6.3 & 19.9 & 17.1 & 2.1 & & \\
\hline Current account surplus & -6.0 & -8.7 & -9.2 & -6.9 & -5.5 & & \\
\hline Capital and financial account balance & 4.6 & 9.5 & 9.1 & 3.7 & 5.4 & & \\
\hline \multicolumn{8}{|l|}{ Of which } \\
\hline Capital account & 1.5 & 3.2 & 3.0 & 0.9 & 0.5 & & \\
\hline Inward portfolio investment (debt securities, etc.) & -37.3 & -44.5 & -38.7 & 6.7 & 6.5 & & \\
\hline Other investment (loans, trade credits, etc.) & 30.2 & 43.3 & 17.3 & -12.5 & -4.7 & & \\
\hline Inward foreign direct investment & 6.9 & 11.7 & 28.7 & 12.3 & 7.1 & & \\
\hline Gross official reserves (millions of US dollars; e.o.p.) & 2,523 & 2,727 & 2,813 & 3,511 & 3,610 & & \\
\hline Official reserves in months of imports GNFS & 6.5 & 6.6 & 5.7 & 6.1 & 6.1 & & \\
\hline Ratio of foreign reserves to base money (percent) $1 /$ & 135.1 & 141.8 & 146.4 & 165.8 & $\ldots$ & & \\
\hline Ratio of foreign reserves to broad money (percent) $1 /$ & 28.3 & 30.1 & 29.5 & 30.3 & 30.4 & & \\
\hline Exchange rate (per U.S. dollar, period average) & 0.8 & 0.8 & 0.8 & 0.7 & 0.7 & & \\
\hline REER appreciation, CPI-based (period average) & 2.6 & -0.1 & 1.4 & 1.8 & 3.6 & & \\
\hline Change in stock market index (percent, year-to-date) & 44.4 & 62.3 & -2.2 & 1.3 & -35.0 & -4.7 & May \\
\hline
\end{tabular}

CInternational Monetary Fund. Not for Redistribution 


\section{MALTA's BANKING SECTOR \\ ReCENT DeVElopments And Risks to BANKIng SECTOR STABILITy}

45. Risks to the stability of Malta's banking sector have increased over the past few years. The sector has grown in size and in financial linkages with the rest of the world. The developments come with new risks, and, significant progress notwithstanding, supervisory capacities and macro-prudential surveillance will need to keep pace with the rising sophistication of the sector.

\section{A. Broad characteristics of the Maltese banking sector}

46. The banking sector has grown rapidly in recent years (Figure 1). Between 2004 and 2008, the number of institutions increased from 16 to 23 and total assets doubled, to reach $€ 42$ billion, over seven times Malta's GDP. Most of the expansion was led by external assets, which account for over three quarters of total assets at end-2008. Domestic assets also grew briskly, especially in loans for mortgage and broader real estate purposes, and to the transport sector. Property-related loans currently constitute more than half of the domestic loan portfolio. On the funding side, foreign deposits tripled and domestic deposits grew by one third over 2004-08.

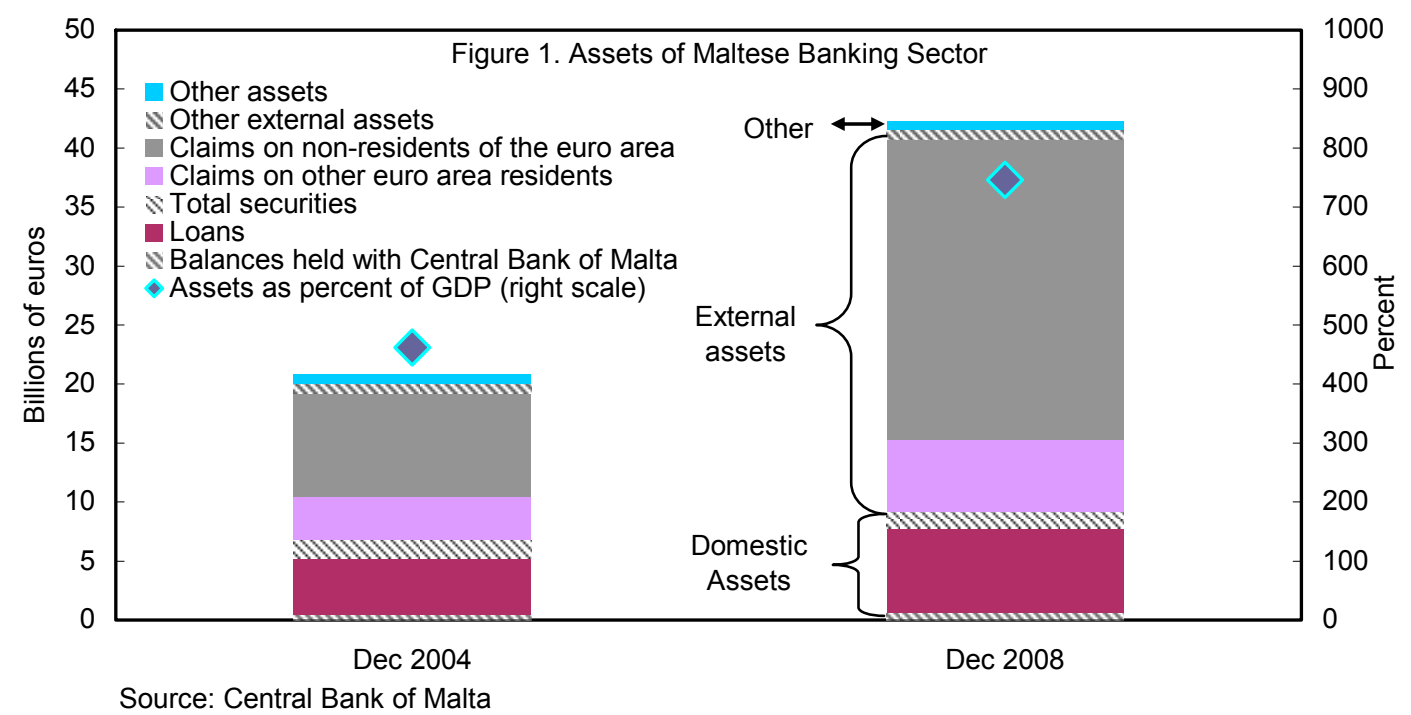

47. The banking sector is heterogeneous, with only a small fraction of institutions playing a role in domestic financial intermediation. Of the 23 banks, 13 are locally incorporated subsidiaries of foreign institutions and three are foreign branches. ${ }^{6}$ However, according to the Central Bank of Malta (CBM) only seven of these banks, dubbed domestically oriented institutions (DBI) play a role in domestic intermediation. ${ }^{7}$ Four of

\footnotetext{
${ }^{6}$ EU subsidiaries and branches are from Austria, the UK, Portugal and the Netherlands; two of the non-EU subsidiaries are from Saudi Arabia, while all non-EU branches are Turkish.

${ }^{7}$ The CBM in its 2008 Financial Stability Report classifies banks as DBIs if they reach a threshold resident exposure of 1 percent combined in different markets (assets, deposits, securities) or participate in the payment
}

(continued...) 
them are foreign-owned. DBIs represent 30 percent of total assets and account for the quasi-totality of resident market transactions, both on the funding and lending side (Figures 2 and 3). In fact, domestic intermediation is concentrated in two banks-one of which is foreign-owned - accounting for about 80 percent of both domestic loans and resident deposits. Domestic lending is largely deposit financed, with a loan-to-deposit ratio at almost 80 percent at end-2008. Most of the remaining 16 internationally-oriented banking institutions (IBIs) use funding from their overseas banking group to finance assets outside Malta, while some others specialize in trade finance outside Malta. Partly because of these differences in business models, performance indicators vary significantly across banks (Figure 4). ${ }^{8}$
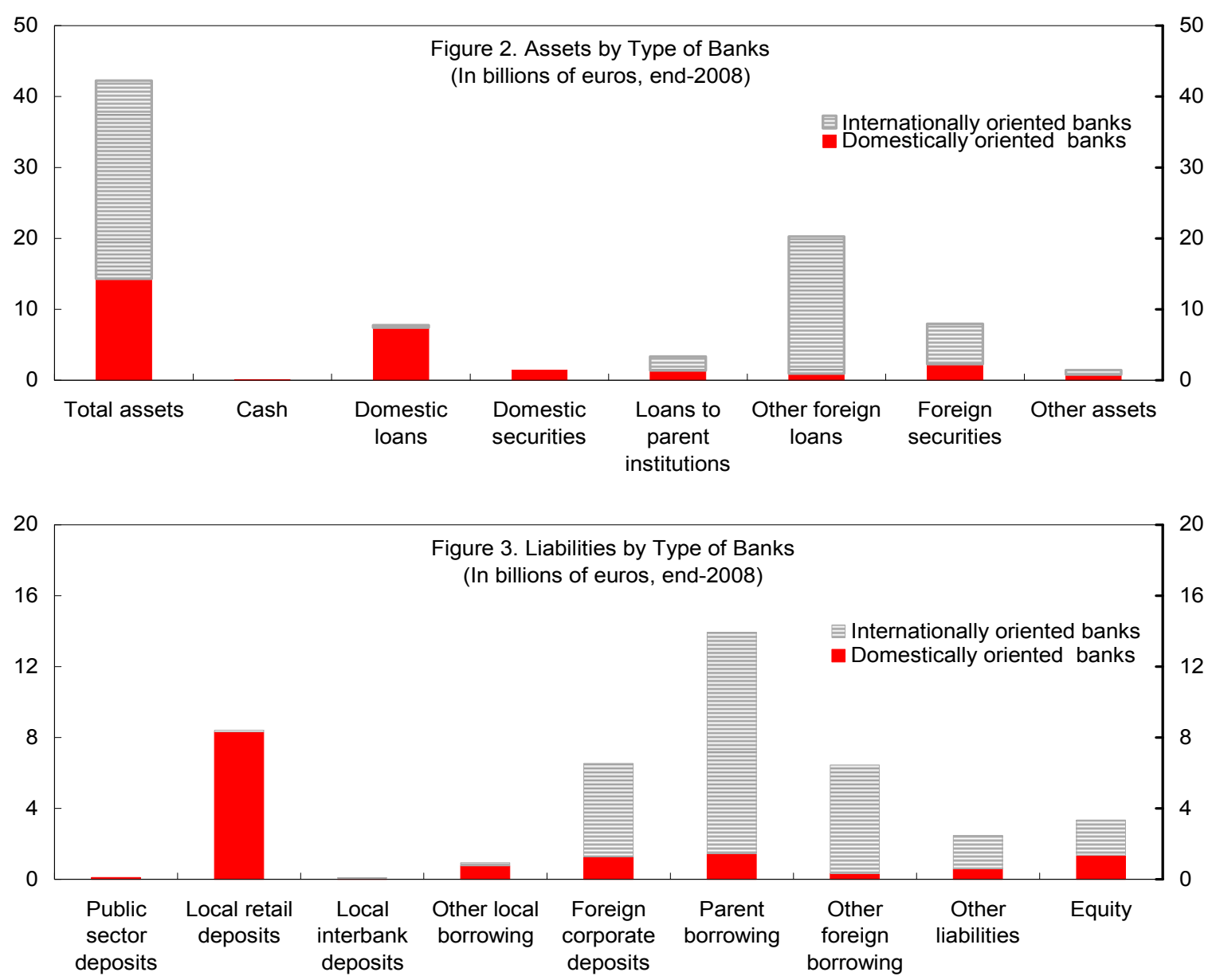

Source: Central Bank of Malta.

Note: Reserves held with central banks are subsumed in domestic loans.

\section{B. Impact of the Global Financial Crisis}

system. A bank that declares its intention to enter the local market would also be included even if its exposure does not reach the threshold.

${ }^{8}$ Malta's favorable tax regime and extensive double-taxation treaties explain in part the presence of IBIs. Under the full imputation system, foreign shareholders receive full credit for tax paid in Malta on distributed profits. 


\section{The Maltese financial sector has withstood relatively well the international}

financial crisis to date. Banks had limited exposure to structured instruments. They were not affected either by the seizing up of global interbank activity, as they depend little on wholesale resources to fund their operations. Moreover, the quality of the lending portfolio and capital indicators have been maintained so far; at end March 2009 , DBIs' nonperforming loan (NPL) ratio stood broadly unchanged at 5.2 percent, while capital adequacy ratios of all banks remained over 17 percent for the whole sector and over 14 percent for DBIs. No intervention to shore up either liquidity or equity in banks has been necessary.

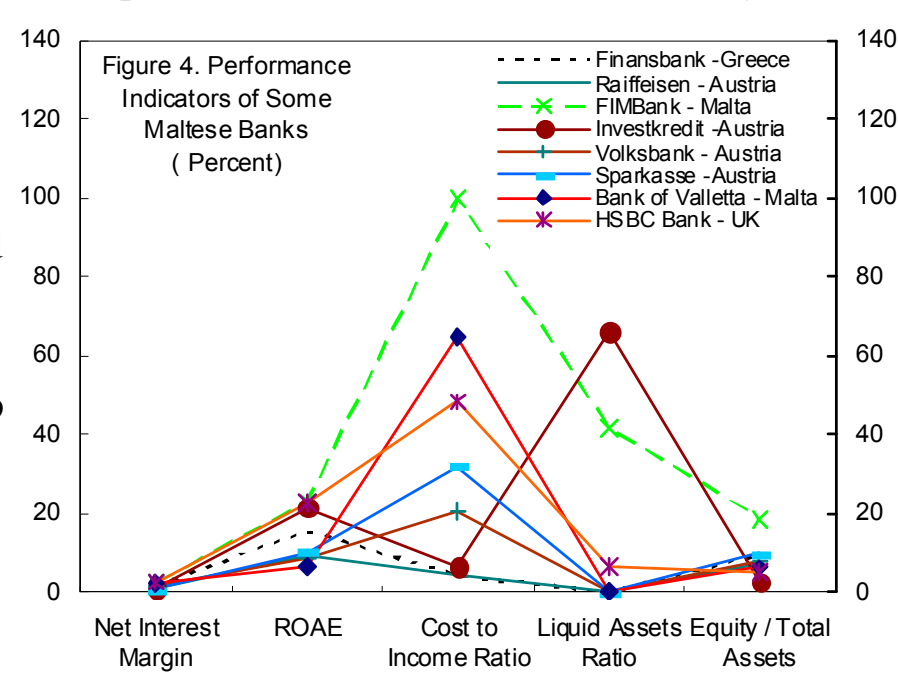

Source: Bancscope. local Note: Data refer to 2007 or 2008. Country name designates location of ownership.

49. The local interbank market continued functioning smoothly. In fact, entry into the euro zone in January 2008 fostered the development of the local interbank market, with the total volume of deals increasing six fold to reach $€ 1.7$ billion in 2008 (Figure 5). As part of the Eurosystem, the CBM has also been injecting liquidity since joining the euro zone. Banks have participated in central bank auctions mainly to take advantage of favorable interest rate conditions rather than because of liquidity shortages.

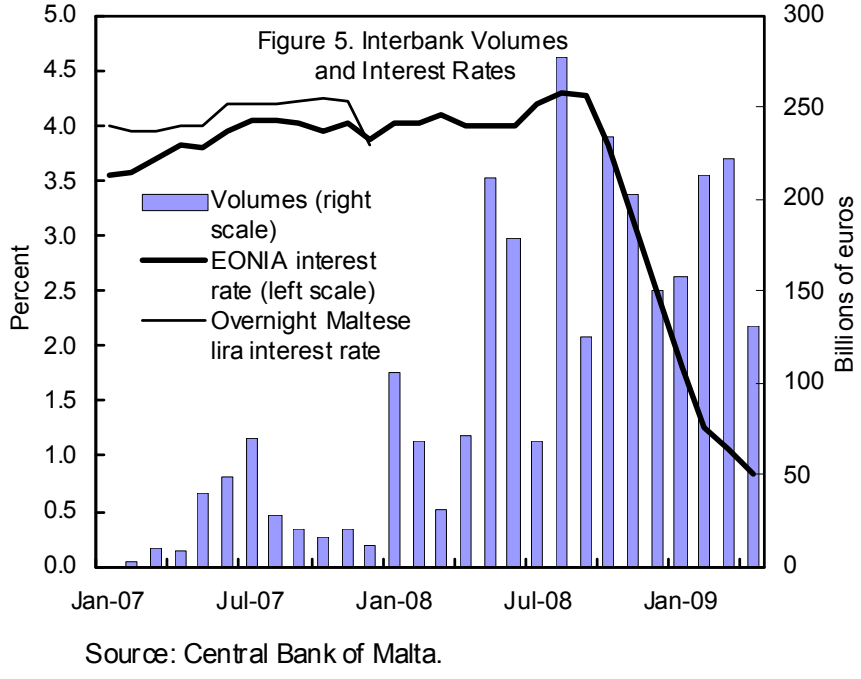

50. Confidence in the local bond market was even conducive to new issuances. With sovereign bond spreads in line with regional peers and with declining market interest rates, a number of local banks and corporates were able to raise finance at attractive yields, in some cases also strengthening overall capital ratios. The largest bank issued a ten year subordinated bond at 5.3 percent in June 2009, only 47 basis points over benchmark government bonds.

51. Still, profitability suffered (Table 1). Unlike IBIs, which reported trading gains, DBIs on aggregate suffered losses on their global and domestic securities portfolio, resulting in negative returns on equity and assets in 2008. The correlation between Maltese banks' and euro-area banks' equity prices increased throughout 2008, a further channel of negative 
spillovers from the global financial turmoil (Figure 6). Equity prices for smaller banks that remained profitable, however, evolved in opposite direction during the height of the crisis.

Table 1. Gains and Losses on Financial Assets, 2008

(In millions of euros, unless otherwise indicated)

\begin{tabular}{lrr}
\hline & DBIs & IBIs \\
\hline On disposal of financal assets and liabilities & -9.1 & 246.3 \\
Fair value movements 1/ & -224.7 & -61.7 \\
From hedge accounting & 2.6 & 0.0 \\
Total & -231.2 & 184.6 \\
$\quad$ As percent of own funds & -16.9 & 9.3 \\
Memorandum items: & & \\
Return on assets (percent) & -0.4 & 1.1 \\
Return on equity (percent) & -3.8 & 11.0 \\
\hline
\end{tabular}

Sources: Central Bank of Malta; and IMF staff calculations.

$1 /$ Most of the movements for DBIs are attributable to one institution, which accounts for a relatively small proportion of total assets.

\section{Risks to Banking Sector Stability}

\section{Comparison with peers} suggests a relatively robust starting point for financial stability in Malta (Tables 2 and 3). Profitability of banks may be lower, but capital buffers seem ample and the liquidity position stronger than in most peer countries. The z-score analysis, using balance sheet data for 1995-2007 confirms that Maltese banks performed slightly above comparators: their z-score exceeds that of banks in Cyprus, but falls just short of those in Portugal ${ }^{9}$.

Table 2. Z-score Decomposition, 1995-07

\begin{tabular}{lrrr}
\hline & Malta & Cyprus & Portugal \\
\hline Z-score & 28.9 & 12.1 & 33.1 \\
Return on assets (percent) & 0.9 & 0.8 & 0.7 \\
Equity to assets ratio (percent) & 6.4 & 6.9 & 5.9 \\
Standard deviation of return on assets (pp) & 0.3 & 0.7 & 0.2 \\
\hline
\end{tabular}

Sources: FSAP Update, Cyprus, May 2009; and IMF staff calculations.

Table 3. Cross-Country Comparison of Financial Soundness Indicators, 2007

\begin{tabular}{lrrrrr}
\hline & Malta & Cyprus & Greece & Portugal & Slovenia \\
\hline Profitability (percent of total assets, unless otherwise indicated) & & & & \\
Net interest income & 2.3 & 2.3 & 2.8 & 1.8 & 2.2 \\
Net non-interest income & 0.5 & 1.4 & 1.3 & 1.3 & 1.6 \\
Total expenses & 1.3 & 1.6 & 2.1 & 1.7 & 2.0 \\
ROA after tax & 1.1 & 1.6 & 1.4 & 0.9 & 1.0 \\
ROE after tax (percent of Tier 1) & 15.5 & 27.4 & 22.4 & 17.1 & 17.6 \\
Cost-to-income ratio & 46.6 & 43.2 & 50.1 & 55.0 & 53.4 \\
Solvency and liquidity (percent) & & & & & \\
Overall solvency ratio & 15.4 & 12.5 & 11.5 & 10.2 & 11.0 \\
Tier 1 ratio & 13.5 & 10.3 & 9.7 & 7.2 & 7.0 \\
Liquid asset ratio (cash and loans to & 137.2 & 298.4 & 89.1 & 91.6 & 35.8 \\
credit institutions) & & & & & \\
\hline
\end{tabular}

Source: European Central Bank.

\footnotetext{
${ }^{9}$ The z-score measures the number of standard deviations a return realization has to fall in order to deplete equity, under the assumption of normality of banks' returns. A higher z score implies a lower probability of insolvency. The calculation for Malta is based on the two largest banks that represent 80 percent of the market. Data for comparator countries cover commercial banks only.
} 


\section{However, in the wake of euro area entry, new risks have emerged as} internationally oriented banks start integrating in the domestic financial sector. First, following euro adoption in 2008, a number of IBIs are now participating in the local interbank market (Figure 7). In fact, transactions between IBIs and DBIs peaked in October 2008, at a time when financial stresses were particularly elevated. ${ }^{10}$ Second, counterparty risk has also increased with euro adoption, as banks still settle accounts via other banks instead of participating directly in the payment system TARGET2. ${ }^{11}$ Lastly, some IBIs started issuing securities on the Maltese stock exchange and lending to residents, while others are collecting

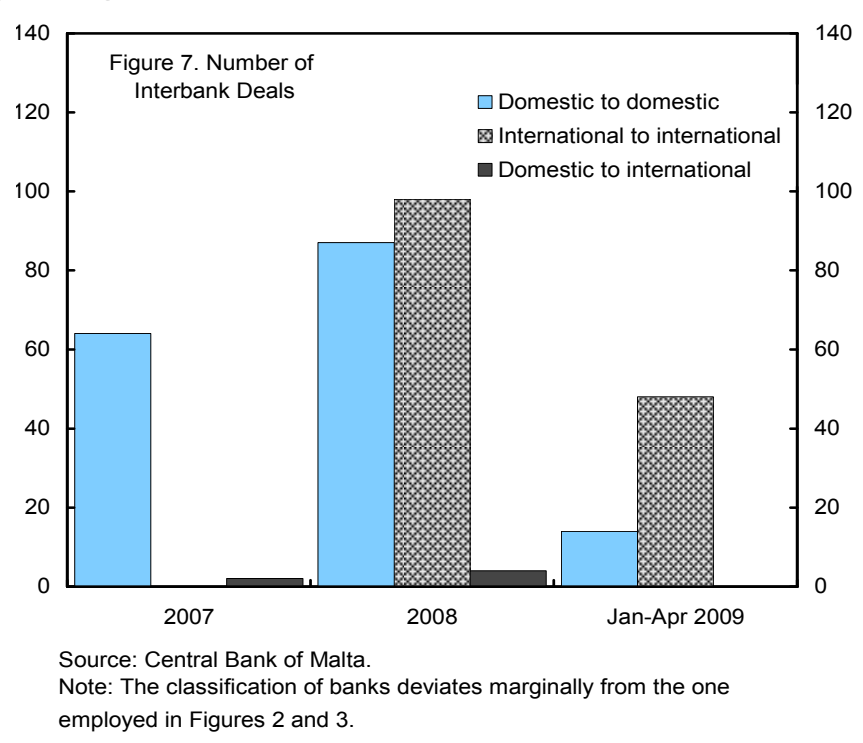
domestic deposits, covered by the local Deposit Guarantee Scheme (DGS). At end 2008, eligible deposits of IBIs under the DGS amounted to about $€ 0.2$ billion. ${ }^{12}$ While this amount only represents $2 \frac{1}{2}$ percent of all eligible deposits, it has been on the rise. Incidentally, it may not be straightforward to monitor risks stemming from IBIs; because these entities often act as simple agents of overseas banking group, their balance sheet information may not provide adequate guidance on underlying risks.

\section{Moreover, DBIs and IBIs are exposed to countries with elevated economic risks,} such as Turkey, the UK or Central and Eastern Europe (CEE). Subsidiaries of Austrian banks (DBIs and IBIs) are mostly exposed to Bulgaria and the Czech Republic; their exposure to CEE stood at $€ 2$ billion, about 170 percent of their own funds at end-January 2009. Total banking sector exposure to the UK amounts to $€ 3.5$ billion, while that to Turkey exceeds $€ 12$ billion. While the latter amounts to one quarter of total assets, it is concentrated in two Turkish branches (IBIs) that have little direct links with the domestic economy. Still, even if the direct impact of stresses at IBIs on DBIs is currently likely to be small, contagion effects due to imperfect information cannot be ruled out. ${ }^{13}$

\footnotetext{
${ }^{10}$ Previously, IBIs did not take part in the Maltese Lira market. IBIs also have interbank exposures with non-resident banks, which could be an additional indirect source of risk to DBIs.

${ }^{11}$ TARGET2 is the real time gross settlement system for the euro, offered by the Eurosystem. It is used for the settlement of central bank operations, large-value euro interbank transfers as well as other euro payments. It provides real-time processing, settlement in central bank money and immediate finality.

${ }^{12}$ Some of the branches also collect deposits, but these do not fall under the Maltese DGS. Amounts have so far remained small.

${ }^{13}$ Under most license agreements of IBIs, non-performing loans are transferred to the parent. While this provision offers partial protection to the domestic financial sector, it may not protect the system in the event of shocks to liquidity, neither to solvency if this information is not widely available to market participants.
} 
55. While positive for competition, the entry of new banks in the domestic market will certainly lead to a further gradual compression of interest margins. Over the past two years, new entrants have emerged targeting the domestic retail sector. The decline in margins, and hence in profitability, is also being reinforced by the sharp euroarea wide decline in lending interest rates, as deposit rates have proved more sticky. Lower margins and the erosion of banks' franchise value may encourage higher risk taking in the future, to the detriment of financial stability.

\section{Rising household indebtedness and large exposures to a declining property market have increased} vulnerabilities to shocks. The share of

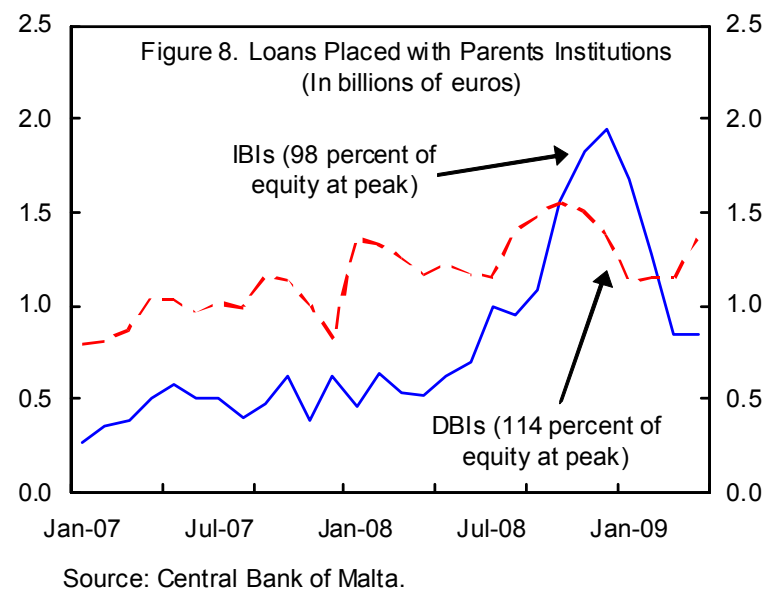
property-related loans in banks' portfolio rose 10 percentage points in 2003-08 to reach 55 percent. Furthermore, loan-to-value (LTV) ratios have been relaxed in past years: according to a CBM survey, LTV ratios above 80 percent were granted to 38 percent of residential property-based loans in 2008, up from 25 percent a year earlier. Both corporate and household indebtedness levels have risen, although they remain below euro area average at about 55 and 65 percent of GDP, respectively. ${ }^{14}$ Furthermore, even though household assets well exceed measured debt, distributional unevenness could contribute to vulnerability. In particular, as property prices are currently undergoing a downward correction, real estate collaterals will offer less protection against loan losses. ${ }^{15}$ The recent top-down stress tests conducted by the CBM on DBIs confirms these vulnerabilities: in the event of a 30 percent drop in house prices, combined with a 15 percent increase in NPLs, three banks would breach regulatory capital thresholds. Risks are compounded by non-negligible single name concentration risks, with the ten largest single name exposures increasing by 10 percent in 2008 .

\section{The considerable expansion in intragroup exposures during the global financial} crisis highlight spillovers risks from overseas parent institutions (Figure 8). For IBIs, lending flows to parent banks more than doubled in the second half of 2008; for DBIs, they increased by 50 percent during July-October 2008 to reach 114 percent of equity. The main purpose of these transfers was to meet liquidity needs of the banking group, at a time when global wholesale markets were dysfunctional. While these flows have substantially receded since then, the event disproportionately exposed local banks to the risk of failure of their parent. Maltese banks are currently exempt from limits on intragroup exposures.

\footnotetext{
${ }^{14}$ This is based on DBIs' outstanding loan book at end 2008. Actual debt, which would include liabilities to the non-bank sector and non-residents, is likely to be higher.

${ }^{15}$ The process of realizing collateral is also considered very slow.
} 


\section{Banks' risk management responses may need reinforcing in the face of these}

new challenges. While lending conditions have been tightened, especially to the construction sector, domestic loan growth has remained brisk, at close to 10 percent year-on-year in April 2009. Though banks have successfully raised fresh capital in 2009, it was concentrated in Tier 2 rather than in core capital. Moreover, banks continued to pay out dividends.

Provisioning, already low by international comparison, has also softened, with coverage ratios of NPL shrinking to 21.6 percent in March 2009 from 24 percent three months earlier. At end 2008, NPL net of provisions represented as much as 27 percent of DBIs' capital. Finally, so far banks do not hold capital specifically against concentration and other Pillar II risks, and stress tests and contingency funding plans have yet to be fully developed. 


\section{INTERNATIONAL MONETARY FUND}

\section{MALTA}

\section{Staff Report for the 2009 Article IV Consultation-Informational Annex}

Prepared by the Staff Representatives for the 2009 Consultation with Malta

Approved by Ajai Chopra and Ranil Salgado

August 5, 2009

Contents

$$
\text { Page }
$$

I. Fund Relations.

.2

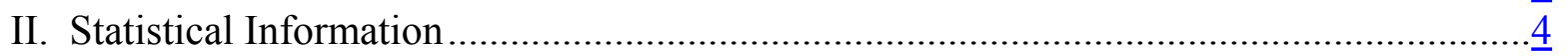




\section{Malta: Fund Relations}

(As of June 30, 2009)

Article IV mission: Discussions were held in Valletta, June 11-22, 2009.

Staff team: Mss. Allard (head), Lusinyan, and Herzberg (all EUR).

Country interlocutors: The mission met with Minister of Finance, Mr. Tonio Fenech; Central Bank of Malta Governor, Mr. Michael Bonello; and other senior officials. It also met with representatives of financial institutions, the private sector, employers and labor unions, opposition, and academics. The authorities agreed to publish the concluding statement.

Data: Malta participates in the IMF's General Data Dissemination System (GDDS) and has targeted subscription to the Special Data Dissemination Standard (SDDS) for end-November 2009.

I. Membership Status: Malta became a member of the IMF on September 11, 1968. It eliminated all remaining restrictions under Article XIV of the Articles of Agreement and accepted the obligations of Article VIII (Sections 2, 3, and 4) of the Articles of Agreement on November 30, 1994.

II. General Resources Account:

Quota

IMF holdings of currency

Reserve position in the IMF

III. SDR Department:

Net cumulative allocation Holdings
SDR Million

102.00

61.74

40.26

SDR Million

11.29

11.82

\section{Percent Quota \\ 100.00 \\ 60.53 \\ 39.47}

\section{Percent Allocation \\ 100.00 \\ 104.69}

IV. Outstanding Purchases and Loans: None

V. Latest Financial Arrangements: None

VI. Projected Payments to the IMF: None

VII. Exchange Rate Arrangement and Restrictions: Malta joined EMU on January 1, 2008 at the central parity of Maltese lira 0.429300 per $€ 1$. Malta maintains an exchange system that is free of restrictions on the making of payments and transfers for current international transactions, except for restrictions maintained for security reasons which have been notified to the IMF pursuant to Executive Board Decision No. 144-(52/51).

VIII. Article IV Consultation: The last Article IV consultation was concluded on August 11, 2008. Malta is on a 12-month Article IV consultation cycle. 
IX. Technical Assistance:

\section{Date}

April 2009

November 2006,

April and December 2007

June 2005

October 2002-January 2003

March 2001

February 1999
Departmen

$\mathbf{t}$

STA SDDS subscription finalization

STA Producer price index/SDDS preparations (expert visits)

STA ROSC Data Module

MFD FSAP missions (joint with World Bank)

STA Money and banking statistics

MAE Monetary operations and liquidity

forecasting

X. Resident Representative: None. 


\section{Malta: Statistical Issues}

Data provision is adequate for surveillance purposes. Significant progress in improving macroeconomic statistics has been made in close cooperation with the European Central Bank (ECB) and Eurostat while upgrading statistical systems to meet the euro area standards. ${ }^{16}$ However, national accounts and balance of payments data have remained subject to substantial revisions, often affecting several years. Most macroeconomic statistics can now be accessed through Eurostat. The country has been a participant in the GDDS since September 11, 2000, with the metadata posted on the IMF's Dissemination Standards Bulletin Board. In 2009, the IMF continued to provide technical assistance to the authorities in order to finalize preparations for SDDS subscription. The review of Malta's data production and dissemination practices found that SDDS requirements are met or exceeded for 17 of the 21 required data components. Planned short-term improvements in the remaining four components - relating to external debt template, the industrial production and producer price indices, and the dissemination of the international investment position (IIP) data - will bring data production and dissemination practices in line with SDDS requirements. In consultation with STA, the target date for SDDS subscription is set for end-November 2009.

Real sector statistics: Data on retail and consumer prices, labor market indicators, and tourism arrivals are released monthly, usually with a short lag. These data are available through Eurostat and via the Internet at the Central Bank of Malta (CBM) and the National Statistical Office (NSO) websites. Presently the NSO releases national accounts data in euros with one quarter lag. Statistical discrepancies (captured under stock building) are often large, particularly on the first release, and typically lead to sizable revisions. Supply-side GDP estimates by type of economic activity are not available, but the recently published producer price index will facilitate their compilation. A planned monthly manufacturing output index with timeliness of one month is expected to be available for public dissemination before end-2009. National accounts imports and exports data are not disaggregated into goods and services. The harmonized index of consumer prices was first published in May 2004.

Government finance statistics: Fiscal statistics meet basic requirements, with quarterly accrual-based data on general government operations compiled in accordance with the ESA95 methodology and disseminated with a one-quarter lag. The general government comprises data from the consolidated fund of government adjusted to include other accounts of government, the accruals elements, and the financial performance of the Extra Budgetary Units and of the Local Councils. The NSO also publishes monthly statistics on the cash operations of the central government, for which the authorities plan to utilize the targeted

\footnotetext{
${ }^{16}$ The 2007/08 Eurostat peer review on the implementation of the European Statistics Code of Practice found that the NSO had reached a remarkable compliance with large parts of the Code despite its small size, but underscored the need to improve adequacy of resources and data quality management.
} 
timeliness flexibility option in light of additional time required for the final month of the fiscal year.

Monetary and financial statistics: Monetary statistics are timely and of good quality. Since the entry into the euro area in January 2008, monetary data for IMF statistical publications are now obtained through a gateway arrangement with the ECB, thus reducing the reporting burden of the country. The country participated in the pilot project-Coordinated Compilation Exercise - for Financial Soundness Indicators and submitted indicators as of end-2005 along with metadata, which are now available to the public through the IMF's website (http://www.imf.org/external/np/sta/fsi/part.asp?iso=MLT).

External sector statistics: Summary data (merchandise trade, current account balance, and selected financial account data) are released on a quarterly basis with a lag of about three months. More detailed BOP and IIP data are released annually, the latter with a lag sometimes exceeding one year. Summary trade statistics are released monthly with a lag of about 40 days. The CBM plans to disseminate the external debt template in line with requirements of the SDDS and recommendations of the External Debt Guide as well as make some minor changes (in coverage and classification) to the Reserves Template currently being disseminated. It is also expected that Malta would be in a position to disseminate the 2009 IIP data with an SSDS required timeliness of three quarters. 
Malta: Table of Common Indicators Required for Surveillance

(As of July 15, 2009)

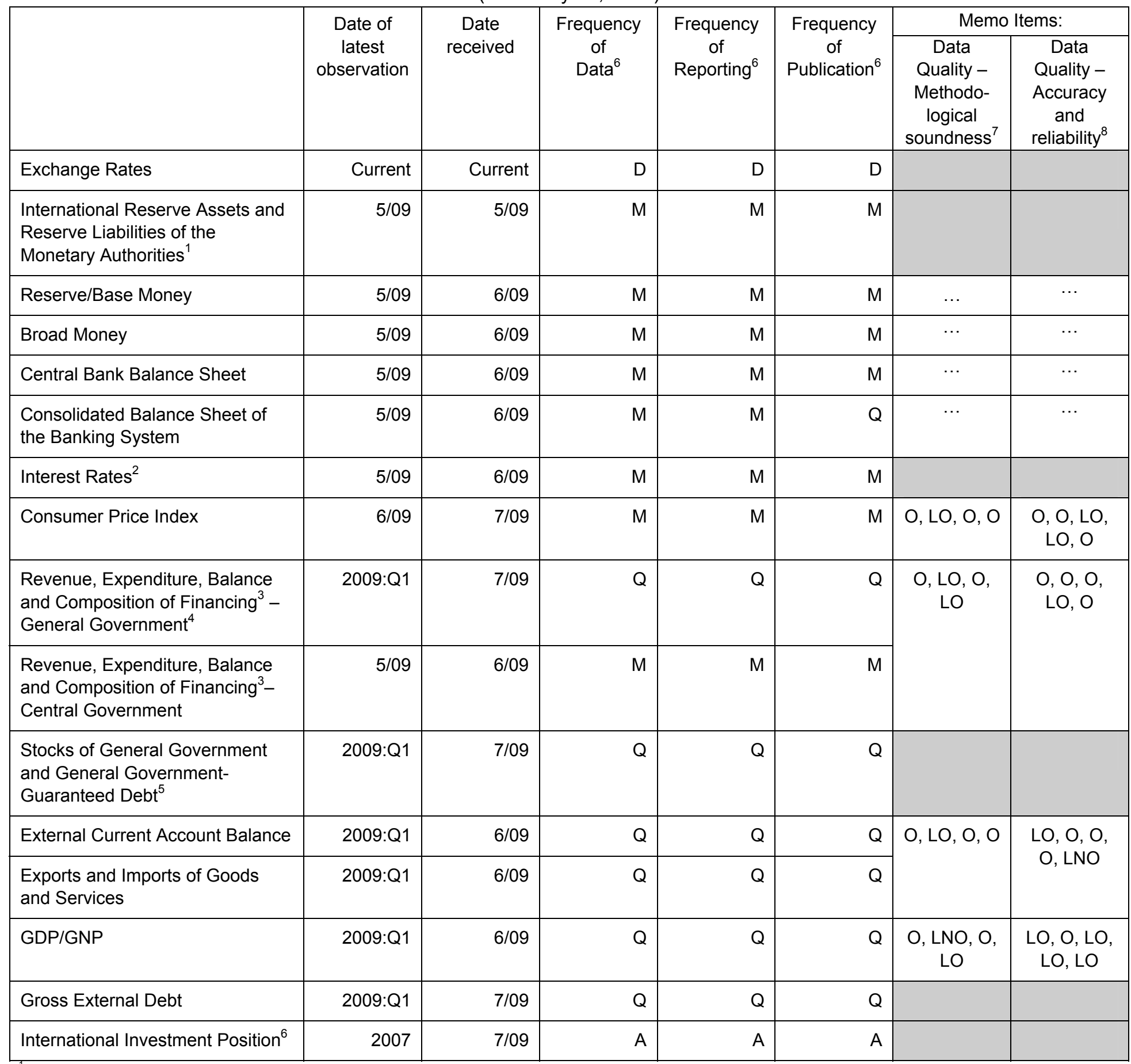

${ }^{1}$ Includes reserve assets pledged or otherwise encumbered as well as net derivative positions.

${ }^{2}$ Both market-based and officially determined, including discount rates, money market rates, rates on treasury bills, notes and bonds.

${ }^{3}$ Foreign, domestic bank, and domestic nonbank financing.

${ }^{4}$ The general government consists of the central government (budgetary funds, extra budgetary funds, and social security funds) and state and local governments.

${ }^{5}$ Including currency and maturity composition.

${ }^{6}$ Includes external gross financial asset and liability positions vis a vis nonresidents.

${ }^{7}$ Daily (D); weekly (W); monthly (M); quarterly (Q); annually (A); irregular (I); and not available (NA).

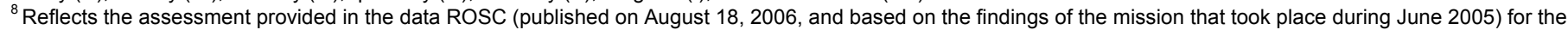
dataset corresponding to the variable in each row. The assessment indicates whether international standards concerning concepts and definitions, scope,

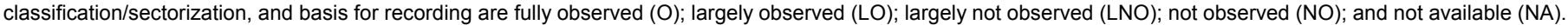

9 Same as footnote 7 , except referring to international standards concerning source data, statistical techniques, assessment and validation of source data, assessment, and revision studies. 


\section{INTERNATIONAL MONETARY FUND}

Public Information Notice

EXTERNAL

RELATIONS

DEPARTMENT

Public Information Notice (PIN) No. 09/116

International Monetary Fund

FOR IMMEDIATE RELEASE

September 14, 2009

$70019^{\text {th }}$ Street, NW

Washington, D. C. 20431 USA

\section{IMF Executive Board Concludes Article IV Consultation with Malta}

On September 4, 2009, the Executive Board of the International Monetary Fund (IMF) concluded the Article IV consultation with Malta. ${ }^{1}$

\section{Background}

After a period of sustained expansion following successful EU entry, Malta started feeling the effects of the global downturn in the fall of 2008, with declining trade flows and investment. More recently, private consumption also weakened, as the labor market prospects deteriorated, and growth slowed substantially in the early-2009. Although inflation has begun moderating recently, it has remained the highest in the euro area since October 2008, and reached 3.4 percent in the second quarter of 2009 , mostly as a result of a lagged impact of energy price increases and imperfect pass-through in food prices.

Fiscal consolidation came to a halt in 2008 , with the deficit widening to over $4 \frac{1}{2}$ percent of GDP, both as the result of restructuring measures in the state-owned shipyards and of spending slippages, most notably in energy subsidies and the health care sector. With the economy deteriorating, the authorities are letting the automatic stabilizers play and are implementing a stimulus package, focused on infrastructure projects and support to the

\footnotetext{
${ }^{1}$ Under Article IV of the IMF's Articles of Agreement, the IMF holds bilateral discussions with members, usually every year. A staff team visits the country, collects economic and financial information, and discusses with officials the country's economic developments and policies. On return to headquarters, the staff prepares a report, which forms the basis for discussion by the Executive Board. At the conclusion of the discussion, the Managing Director, as Chairman of the Board, summarizes the views of Executive Directors, and this summary is transmitted to the country's authorities.
}

Washington, D.C. 20431 • Telephone 202-623-7100 • Fax 202-623-6772 • www.imf.org 
manufacturing and tourism sector. The authorities have managed to finance the fiscal deficit without difficulties, although at a higher cost, but the debt ratio has started to inch up again.

Banks have so far withstood the global financial turmoil relatively well, as they were protected by their limited exposure to structured products, a traditional retail funding model, and conservative lending policies. Credit has proved resilient, and no government intervention to shore up capital or liquidity has been necessary. Nonetheless, some institutions suffered large valuation losses on their security portfolio, and credit concentration in the construction and real estate sectors remains a concern, especially as property prices have fallen noticeably recently.

The external current account deficit narrowed to 51/2 percent of GDP in 2008, reflecting continuous efforts at export diversification and value-added upgrading. Competitiveness has therefore remained broadly stable, notwithstanding moderate appreciation of the real effective exchange rate driven by accelerating wage costs, weakening labor productivity gains, and the strengthening of the euro. Nonetheless, labor market participation remains low, particularly for women, and education attainment trails peers. Furthermore, wage flexibility is limited by an automatic indexation to inflation.

\section{Executive Board Assessment}

The Executive Directors noted that past efforts at fiscal consolidation and export diversification toward high-value-added services activities in the run-up to euro adoption had increased the resilience of the Maltese economy. Nevertheless, the global crisis had started to affect the manufacturing and tourism sectors, weakening growth prospects and jeopardizing the hardwon gains. The main challenges facing policymakers in the current environment are to remain supportive in the short run without compromising the fragile fiscal position, and to preserve competitiveness as a foundation for medium-term growth.

Directors considered that the fiscal stance for 2009 is appropriately accommodative. The full play of automatic stabilizers, combined with a limited stimulus package focusing on infrastructure investment, should provide an adequate counter-cyclical response to the slowdown. Directors encouraged the authorities to improve the composition of the fiscal stimulus by winding down measures to support enterprises as the implementation of planned investment projects gathers pace. While recognizing the need to avoid premature withdrawal of fiscal support, Directors considered it important that consolidation efforts start as soon as feasible, with a number suggesting frontloaded measures in order to reach the Maastricht deficit target by 2010. Directors called for a well-articulated medium-term consolidated strategy, supported by a strengthened institutional framework and budget execution discipline. This would require targeted action on the expenditure side, particularly with regard to the wage bill, social transfers, and pension and health care spending. Directors welcomed recent steps to privatize the shipyards industry and eliminate utility subsidies. 
Directors observed that the banking sector has weathered the global crisis relatively well and capital ratios remain adequate. However, rising nonperforming loans and credit concentration in the context of the downward correction in property prices and the economic slowdown have increased vulnerabilities. Directors recommended that banks build additional capital buffers and set provisioning more proactively. Directors looked forward to the early finalization of legislation on a bank resolution regime and deposit insurance coverage.

Directors saw merit in reassessing the costs and benefits of Malta's banking business model, in view of the risks brought to light by the global financial crisis. Noting the rapid expansion of internationally oriented banks and their increasing linkages with the domestic economy, Directors welcomed ongoing efforts to conduct stress tests and risk assessments, and to gradually incorporate these institutions into the exercise. Containing these risks would require supervisors to further enhance capacities and to better incorporate systemic considerations into prudential standards.

Directors noted that euro area membership provides a clear opportunity for Malta in terms of trade and financial integration. At the same time, it highlights the urgency of improving internal flexibility to remain competitive, especially given persistent inflation in Malta. A concerted effort would be necessary to complete the difficult reform agenda focusing on cost adjustments and productivity improvements, in particular a move toward productivity-linked wage increases and a restructuring of public enterprises. Directors welcomed progress in utility tariff reform, and recommended that the new price-setting formula be applied fully and transparently.

Public Information Notices (PINs) form part of the IMF's efforts to promote transparency of the IMF's views and analysis of economic developments and policies. With the consent of the country (or countries) concerned, PINs are issued after Executive Board discussions of Article IV consultations with member countries, of its surveillance of developments at the regional level, of post-program monitoring, and of ex post assessments of member countries with longer-term program engagements. PINs are also issued after Executive Board discussions of general policy matters, unless otherwise decided by the Executive Board in a particular case. The staff report (use the free Adobe Acrobat Reader to view this pdf file) for the 2009 Article IV Consultation with Malta is also available. 
Malta: Selected Economic Indicators, 2005-10

\begin{tabular}{|c|c|c|c|c|c|c|}
\hline & 2005 & 2006 & 2007 & 2008 & $\begin{array}{c}2009 \\
\text { Proj. }\end{array}$ & $\begin{array}{l}2010 \\
\text { Proj. }\end{array}$ \\
\hline Real economy (constant prices) & \multicolumn{6}{|c|}{ (change in percent) } \\
\hline Real GDP & 4.0 & 3.3 & 4.2 & 2.5 & -2.1 & 0.5 \\
\hline Domestic demand & 6.3 & 3.0 & 2.7 & 2.0 & -1.5 & 0.4 \\
\hline CPI (harmonized, average) & 2.5 & 2.6 & 0.7 & 4.7 & 2.8 & 2.5 \\
\hline Unemployment rate (in percent) $1 /$ & 7.2 & 7.1 & 6.4 & 5.8 & 7.3 & 7.6 \\
\hline Gross national savings (percent of GDP) & 12.0 & 12.9 & 16.0 & 14.2 & 13.8 & 14.1 \\
\hline Gross capital formation (percent of GDP) & 20.7 & 22.2 & 23.0 & 19.7 & 19.6 & 19.8 \\
\hline Public finance & \multicolumn{6}{|c|}{ (general government; in percent of GDP) } \\
\hline Overall balance & -2.9 & -2.6 & -2.2 & -4.6 & -4.5 & -4.4 \\
\hline Primary balance & 0.8 & 1.0 & 1.1 & -1.4 & -1.1 & -0.8 \\
\hline Gross debt & 69.8 & 63.6 & 61.7 & 63.0 & 67.7 & 70.0 \\
\hline Money and Credit & \multicolumn{6}{|c|}{ (change in percent) } \\
\hline Broad money 2/ & 1.3 & 4.4 & 11.5 & -4.6 & -0.5 & $\ldots$ \\
\hline Credit to nonblank private sector $3 /$ & 5.6 & 10.3 & 12.2 & 12.2 & 13.7 & $\cdots$ \\
\hline Interest rates (year average) & \multicolumn{6}{|c|}{ (in percent) } \\
\hline Interest rate for mortgage purposes 4/ & 4.5 & 4.7 & 5.3 & 5.0 & 3.5 & $\cdots$ \\
\hline Ten-year government bond yield 4/ & 4.6 & 4.3 & 4.7 & 4.8 & 4.6 & 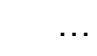 \\
\hline Balance of payments (in percent of GDP) & \multicolumn{6}{|c|}{ (in percent of GDP) } \\
\hline Current account balance & -8.7 & -9.2 & -6.9 & -5.5 & -5.8 & -5.7 \\
\hline Trade balance (goods and services) & -5.3 & -4.9 & -2.8 & -3.2 & -4.4 & -4.3 \\
\hline Exports of goods and services & 77.0 & 87.0 & 89.3 & 80.1 & 65.8 & 67.2 \\
\hline Imports of goods and services & 82.3 & 91.9 & 92.1 & 83.3 & 70.1 & 71.5 \\
\hline Goods balance & -18.8 & -18.9 & -17.9 & -20.4 & -24.9 & -26.2 \\
\hline Services balance & 13.5 & 13.9 & 15.1 & 17.2 & 20.5 & 21.9 \\
\hline \multicolumn{7}{|l|}{ Fund position (as of June 30, 2009) } \\
\hline Holdings of currency (in percent of quota) & & & & & 60.5 & \\
\hline Holdings of SDRs (in percent of allocation) & & & & & 104.7 & \\
\hline Quota (in millions of SDRs) & & & & & 102.0 & \\
\hline \multicolumn{7}{|l|}{ Exchange rate } \\
\hline Exchange rate regime & \multicolumn{6}{|c|}{ Joined EMU on January 1, 2008} \\
\hline Nominal effective rate $(2000=100)$ & 106.7 & 107.8 & 111.1 & 113.6 & $\ldots$ & $\ldots$ \\
\hline Real effective rate, CPI-based $(2000=100)$ & 108.3 & 109.7 & 111.7 & 115.7 & $\ldots$ & $\ldots$ \\
\hline Real effective rate, ULC-based $(2000=100)$ & 114.7 & 115.8 & 118.4 & 120.7 & $\ldots$ & $\ldots$ \\
\hline
\end{tabular}

Sources: National Statistical Office; Central Bank of Malta; Eurostat; European Commission; and IMF staff estimates.

1/ EU Labor Force Survey.

2/ Series present a structural break in 2008. For 2009, January-May year-on-year growth.

$3 /$ Loans to nonfinancial corporate sector and households/individuals. For 2009, January-May year-on-year growth.

4/ for 2009, January-May average. 


\section{Statement by Arrigo Sadun, Executive Director for Malta and Francesco Spadafora, Senior Advisor to Executive Director September 4, 2009}

On behalf of the Maltese authorities, we thank staff for the well-written and informative report, which once again witnesses the fruitful and close cooperation with the authorities.

\section{Overview}

The global crisis resulted in an external shock that is testing the resilience of the Maltese economy. Annual growth averaged 3.5 percent over the last four years, but it will turn into negative territory (at around 2 percent) in 2009, driven by declines in all private components of demand. In particular, exports in the manufacturing and tourism sectors have fallen as a result of the recession affecting Malta's trade partners. On the positive side, the services balance continues to improve due to the significant diversification of activities into higher value-added productions that took place over the last few years. The services balance is projected to increase to over 20 percent of GDP in 2009, up from about 17 percent one year ago.

For 2010 staff expect a modest recovery, with growth at about 0.5 percent, driven by improvements in external conditions. While agreeing that risks prevail on the downside, the authorities are somewhat more optimistic on account of expectations for resiliency in consumption and a more robust pick-up in corporate investment.

In the labor market, the robust activity in the services sector contributed to the satisfactory rate of job creation until the end of 2008, but conditions deteriorated afterwards. After having declined for three years in a row, the unemployment rate is projected to increase to 7.3 percent in 2009 , still below the euro area average by about 2 percentage points.

Inflation remains at a relatively high level, a reflection of buoyant food, energy, and hotel prices. The inflation differential with the euro area in energy prices is expected to decline in the near future, helped by the downward adjustment in utility prices adopted by the authorities in April 2009. More generally, inflation will be brought down by the negative output gap projected through 2014.

FDI inflows, attracted by Malta's stable institutional and business environment, have continued to overfinance a stabilizing current account deficit, thus strengthening the country's net external position.

\section{Fiscal Policy}

The authorities responded to the global crisis by allowing a full play of automatic stabilizers, and by adopting a stimulus package of 1.5 percent of GDP, partly financed by EU grants. The package focuses on measures to increase public investment in order to upgrade the country's infrastructure and further increase Malta's attraction as an FDI destination. 
At the same time, the authorities foresee a fiscal consolidation of 0.75 percent of GDP in 2009, fully accounted for by cuts in subsidies on utilities. Moreover, to rein in public expenditures, the authorities have taken corrective measures with regard to the shipyards sector.

The authorities are committed to resume fiscal consolidation, when cyclical conditions improve, in order to reduce the budget deficit to below the 3 percent threshold and terminate the Maastricht Treaty's excessive deficit procedure.

The authorities agree with staff that fiscal consolidation should be essentially expenditure-based. Currently, preparations for the 2010 budget are underway and, in this context, the authorities are considering measures to reduce government expenditure in a number of areas. This process will also involve consultation with the social partners. The authorities also see with favor a strengthening of the fiscal framework and budget execution discipline. To this end, initial steps have been taken to increase oversight of spending ministries.

The authorities are mindful of the potential side effects mentioned by staff with regard to their measures to support a small number of manufacturing enterprises, but they see them as instrumental in shoring up investors' confidence in the Maltese economy.

\section{Financial Sector}

Over the last few years, the financial sector has grown in size and sophistication, reaching over seven times GDP, driven by internationally oriented banks that account for 70 percent of total assets. The global crisis has had a contained impact on Maltese banks so far. Domestically oriented banks have been virtually unscathed by the turmoil, as they lack exposure to structured financial products and rely on a traditional funding model based on retail deposits. This safe structure also underpins the resilience of credit to the private sector.

While banks' profitability has been hurt, capital ratios, although declining, have remained well above regulatory minima and the liquidity position is stronger than in most peer countries. The local interbank market, whose development was fostered by the 2008 euro adoption, continues to function smoothly.

At the height of the crisis, the government committed to support banks, but so far there has been no need to actually provide additional capital or liquidity. A number of banks have been able to raise capital by tapping capital markets at relatively favorable price conditions.

Against this background, the authorities are aware that the financial turmoil has inevitably raised some vulnerabilities.

Rising nonperforming loans and the concentration of domestically oriented banks' exposures in the construction and real estate sector are a source of concern. The authorities' have conducted stress tests to better identify the risks; they agree with staff that a more proactive stance towards strengthening capital buffers is appropriate. 
In view of the increased participation of internationally oriented banks in the domestic interbank market, the central bank has gradually incorporated these intermediaries in its stability assessment and stress testing exercises.

In December 2008, a "crisis impact assessment" was conducted jointly by the Ministry of Finance, the Central Bank of Malta, and the Malta Financial Services Authority to assess the channels of transmission in case of financial distress, and to evaluate communication between the different authorities. Going forward, in order to better gauge systemic risk, the authorities intend to run a stress testing exercise that will involve the central bank, the supervisor, and individual banks.

The authorities are also taking the legislative steps needed to increase funding for the depositguarantee scheme, and to modernize the regimes for crises management and bank resolution. Communication to the public has been enhanced through the publication of the financial stability report.

\section{Structural Reforms}

So far, the authorities have concentrated on supporting the economy in order to mitigate the fallout from the crisis, but they are committed to resume efforts to increase the economy's competitiveness and attractiveness to FDI. As noted by staff, the country's competitive position has evolved in line with structural changes in the export structure towards higher value-added sectors, and has remained broadly stable in the face of the downturn, with the euro shielding it from unnecessary currency volatility.

To further reduce the state's involvement in the economy, the authorities are finalizing the privatization of the shipyards' activities, and the unbundling of Enemalta's gas and petroleum divisions. To reduce the potential fiscal consequences posed by the state-owned energy and water utility companies, the authorities have introduced a rule-based mechanism to determine electricity and water tariffs with a view to gradually achieving full cost recovery.

The authorities are aware of the need to tackle the causes of persistent inflation in a timely manner. Staff recommend that adequate capacities and institutional independence should be granted to the competition authority so that it may adopt a more proactive stance toward addressing any monopolistic behavior in the wholesale and retail markets. The authorities' view is that the recommendation to grant institutional independence to the competition authority is premature, but they agree that a proactive stance is crucial in fostering price flexibility and efficient markets.

The authorities noted staff's remarks on the existing across-the-board mandatory inflation adjustment of wages (COLA), but point out that the indexation mechanism had served the country well; they expressed cautious support for staff's suggestion of a social pact to forge consensus on required policies. 